Bulletin 9

DEPARTMENT OF THE INTERIOR B UREA U OF M I N S JOSEPH A. HOLMES. Director

\title{
RECENT DEVELOPMENT OF THE PRODUCER-GAS POWER PLANT IN THE UNITED STATES
}

\author{
BY \\ ROBERT HEYWOOD FERNALD
}

(Reprint of United States Geological Survey Bulletin 416)

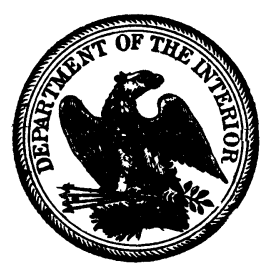

WASHINGTON

GOVERNMENT PRINTING OFFICE 



\section{CONTENTS.}

Introduction Page.

Rapid development of the gas engine................................ 6

Development of the gas producer for power purposes................... 7

Producer-gas tests by the United States Geological Survey............... 8

Description of plant....................................... 8

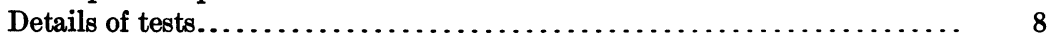

Relative results of steam and producer-gas tests.................... 13

Efficiencies............................................... 19

Views of manufacturers of producer-gas power plants................... $\quad 19$

Present status of the producer-gas power plant....................... 23

Reliability.................................................. 23

Lack of engineers............................................ 27

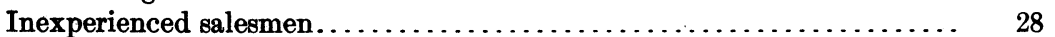

Unsuccessful installations.................................... 28

Design and construction....................................... 28

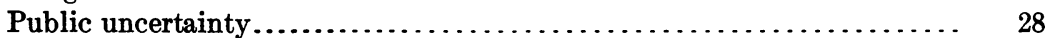

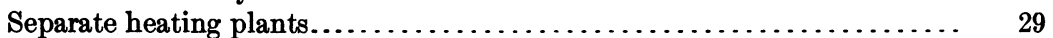

Use with bituminous coal.................................... 29

Cheap fuels in suction producers............................... 31

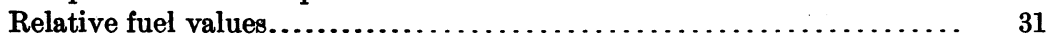

Excessive cost. . . . . . . . . . . . . . . .

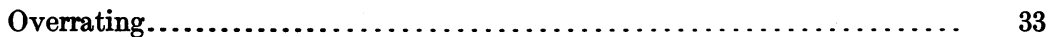

Views of owners and operators of producer-gas plants.................... 34

Number and class of plants..................................... 34

Notes of inspection............................................ 35

Deductions from visits of inspection............................ 61

Number and distribution of producer-gas power plants................. 61

Centralization of power development and distribution.................... $\quad 79$

Increase in number of central stations.............................. $\quad 79$

European examples of advantageous location........................ $\quad 79$

Favorable conditions in the United States....................... 80

Survey publications on fuel testing $\ldots \ldots \ldots \ldots \ldots \ldots \ldots \ldots \ldots \ldots \ldots \ldots, 81$ 


\section{ILLUSTRATIONS.}

Plate I. Geographic distribution of producer-gas power plants in the United States, according to number of plants in each locality......... In pocket.

II. Geographic distribution of producer-gas power plants in the United States, according to total horsepower of plants in each locality. In pocket.

Frgure 1. Comparative service of coals and lignites in gas-producer and steamboiler plants.................................... 17

2. Annual increase in number of producer-gas power plants in the United

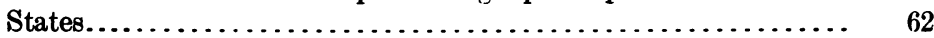

3. Annual increase in the total horsepower of producer-gas power plants

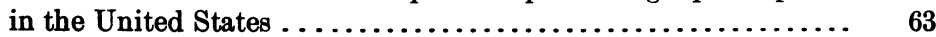




\title{
RECENT DEVELOPMENT OF THE PRODUCER-GAS POWER PLANT IN THE UNITED STATES.
}

\author{
By Robert Heywood Fernald.
}

\section{INTRODUCTION.}

The United States Geological Survey has for several years been investigating the economic value of coals and lignites as gas-producer fuel. This work began with tests of coal and lignite at the coaltesting plant erected at the Louisiana Purchase Exposition, St. Louis, Mo., in 1904, was continued at St. Louis and at Norfolk, Va., and is now being carried on by the Survey at the fuel-testing plant in Pittsburg, Pa. The tests were undertaken because it was evidently desirable to determine the value of the gas producer as a means of increasing efficiency in the use of the coal supplies of the United States. The early tests proved decidedly encouraging, demonstrating that many coals now wasted or not mined because they are not satisfactory fuel for steam-power plants can, by conversion into producer gas, be made to do from two to three times as much work as can be done by the best grades of steam coal burned in a boiler plant. In consequence, the making of producer-gas tests and the study of the processes that take place within the gas producer now form an esential part of the fuel investigations conducted at the Pittsburg plant under the provisions made by Congress for the analyzing and testing of mineral fuels.

A summary of the tests made at St. Louis and a résumé of the conclusions to be drawn from the tests and from the opinions of gas-producer manufacturers on the status of the gas producer and gas engine was published in a Survey bulletin in $1907 .{ }^{a}$ Interest in the widespread application of the producer-gas power plant in this country has become so keenly awakened and the demand for information upon this subject has become so general that it is deemed wise to present at this time more complete information regarding producer-gas power-plant installations than was given in that bulletin.

a Fernald, R. H., The present status of the producer-gas power plant in the United States: Contributions to economic geology, 1906, pt. 2: Bull. U. S. Geol. Survey No. 316, 1907, pp. 439-459. 
As it is desirable to repeat much of the material that appeared in the former bulletin (now out of print), this presentation may be regarded as a revision of the previous one, although considerable information not previously available for publication has been added.

Special care has been exercised to secure authentic reports and data relating to producer-gas power plants, and an effort has been made to present the subject in its various aspects with complete frankness and freedom from prejudice.

With this aim in view, the information relating to the details of operation of various plants was secured by personal inspection, either by me or by Mr. Carl D. Smith, assistant engineer, United States Geological Survey.

The lists of installations, together with the data for them, were obtained through the courtesy of the manufacturers, and the opinions expressed regarding the degree of success which may be expected from producer-gas plants, when properly handled, were secured directly from the owners and operators of these plants.

\section{RAPID DEVELOPMENT OF THE GAS ENGINE.}

It was not until late in the nineteenth century that the gas engine came into common use, and although many types have been devised within the last twenty or thirty years it is only within eight or nine years that large gas engines have been constructed. This development started eleven or twelve years ago in Germany, Belgium, and England, but marked progress has been limited to the last eight years.

For a long time the natural fuel of these internal-combustion engines was city gas, but this was too expensive except for engines of small capacity. It was seldom found economical to operate units of more than 75 horsepower with this fuel. Cheap gas was essential for the development of the gas engine, but the early attempts to produce cheap gas were somewhat discouraging, and for a time it seemed very unlikely that the gas engine would encroach to any extent on the field occupied by the steam engine The theoretical possibilities of the internal-combustion engine operating with cheap fuel promised so much, however, that the practical difficulties were rapidly overcome, with the result that the internal-combustion engine has become a serious rival of the steam engine in many of its applications.

The development of the large gas engine within the last few years has been exceedingly rapid. It was only nine years ago that a 600-horsepower engine exhibited at the Paris exposition was regarded as a wonder, but to-day four-cycle, twin-tandem, double-acting engines of 2,000 to 3,500 horsepower can be found in nearly all up-to-date steel plants, and there are installations in this country containing several units rated at 5,400 horsepower each. 


\section{DEVELOPMENT OF THE GAS PRODUCER FOR POWER PURPOSES.}

The rapid advance of the large gas engine was made possible by improvements in the production of cheap gas directly from fuel by means of the gas producer. An early form of producer introduced in Europe, and now in general use both abroad and in the United States, is known as the suction producer, a name suggested by the fact that the engine develops its charge of gas in the producer by means of its own suction stroke. Although many producers of this type are now used, most of them are small, seldom exceeding 200 horsepower. A serious limitation to the utility of the suction producer has been the fact that, owing to the manner of generating the gas, no tarry fuels could be used, a restriction that prevented the use of bituminous coals, lignites, peats, and other like fuels. The fuels in most common use for producers of this type are charcoal, coke, and anthracite coal, although attempts are being made so to construct suction plants that they can be operated with bituminous or tarry coals.

To meet the demand for the concentration of power in large units, instead of operating a large number of separate installations of small power capacity, the pressure producer was devised. This producer develops its gas under a slight pressure due to the introduction of an air and steam blast, and the gas is stored in a holder until it is required by the engine. As the gas may thus be stored before passing to the engine, and as its generation does not depend on the suction stroke of the engine, tar and other impurities may be removed from it by suitable devices, and the use of bituminous coal, lignite, and peat is thus permitted.

The pressure producer was closely followed in the course of development by the down-draft producer, which fixes the tar as a permanent gas and therefore completely uses the volatile hydrocarbons in bituminous coal, lignite, and peat.

A few scattered producer-gas plants were installed for power purposes in the United States before 1900, but the application of this type of power in any general sense has been developed since that date. During the first few years of this period of development anthracite coal, coke, and charcoal were used almost exclusively, although occasionally pressure and down-draft plants ventured to use a well-tried bituminous coal known to be especially free from sulphur and caking difficulties and low in both ash and tar making compounds. The rapid development of the anthracite plant was to be expected, but it remained for the United States Geological Survey in its testing plants at St. Louis and Norfolk to demonstrate the possibility of using in such plants practically all grades of fuel of any commercial value, without reference to the amount of sulphur or tarry matter which they 
contain. Figures 2 and 3 illustrate the very rapid increase in the number of installations and in the total horsepower of the plants operating with bituminous coal and lignite since the beginning of these investigations by the Geological Survey in 1904.

\section{PRODUCER-GAS TESTS BY THE UNITED STATES GEOLOGICAL SURVEY.}

\section{DESCRIPTION OF PLANT.}

The series of tests conducted by the United States Geological Survey from October, 1904, to December, 1907, furnished valuable data as to the relative consumption of coal per horsepower per hour by steam and gas plants.

The steam plant with which these tests were made consisted of two 210-horsepower Heine boilers, furnishing steam to a 250-horsepower simple noncondensing Corliss engine, which was belted to a Bullock electric generator.

The producer-gas plant was a Taylor pressure gas producer No. 7, of 250-horsepower capacity. Connected with the producer was the usual apparatus for cleaning and storing the gas before it is delivered to the engine-the economizer, scrubber, tar extractor, purifier, and holder.

The gas engine was of the three-cylinder vertical Westinghouse type, with cylinders of 19-inch diameter and 22-inch stroke, rated at 235 brake horsepower on producer gas. The engine was belted to a 6-pole 175-kilowatt Westinghouse direct-current generator. The load on the generator was controlled by a water rheostat especially constructed for the purpose, through which also the energy developed was dissipated.

\section{DETAILS OF TESTS.}

By means of the producer-gas plant 168 tests have been made. The fuels used were bituminous coals, lignites, and peats from 26 different States, as indicated below:

Fuels tested at gas-producer plant of the United States Geological Survey, St. Louis, Mo., and Norfolk, Va.

\begin{tabular}{|c|c|c|}
\hline BITUMINOUS COALS. & & BITUMINOUS COALS-Continued. \\
\hline Alabama. & 3 & Oklahoma (Indian Territory) \\
\hline Arkansas. & 2 & Pennsylvania.... \\
\hline Illinois... & 29 & Tennessee..................... \\
\hline Indiana. & 15 & Utah........ \\
\hline Iowa. & 1 & Virginia................... \\
\hline Kansas..... & 2 & Washington $\ldots \ldots \ldots \ldots \ldots \ldots \ldots$ \\
\hline Kentucky ........... & 5 & West Virginia..... \\
\hline Missouri $\ldots \ldots \ldots \ldots \ldots \ldots$ & 1 & Wyoming........ \\
\hline New Mexico........ & 3 & \\
\hline 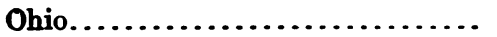 & 10 & \\
\hline
\end{tabular}


Fuels tested at gas-producer plant of the United States Geological Survey, St. Louis, Mo., and Norfolk, Va.-Continued.

\section{SUBBITUMINOUS COALS. $a$}

California .

Colorado.

Washington

Wyoming.

\section{MISCELLANEOUS FUELS-Continued.}

Rhode Island anthracite.......... 1

Virginia pea semianthracite....... 1

Coke breeze.................... 1

Miscellaneous refuse............ 1

Coke...................... 1

11

COALS (DUPLICATE TESTS).

Illinois...................... 2

Indiana...................... 4

Kansas....................... 1

Ohio........................ 1

Pennsylvania.................. 2

MISCELLANEOUS FUELS.

Argentina coal. . . . . . . . . . . . 1

Brazil coal.................... 1

California coal and "front end" cinders....................... 2

Florida peat................. 1

Massachusetts peat..............

Tennessee..................... 1

West Virginia................ 2

LIGNITE (DUPLICATE TEST).

North Dakota................. 1

In the table below is presented a condensed summary of the most important items relating to the coals and lignites tested in the gas producer. The figures are also presented for Florida peat, although but one sample was received. It should be noted that all items in this table which are affected by the load factor are given only for loads ranging from 90 to 100 per cent of full load (235 brake horsepower for this plant).

Summarized items relating to fuels tested in gas producer at St. Louis, Mo., and Norfolk, Va.

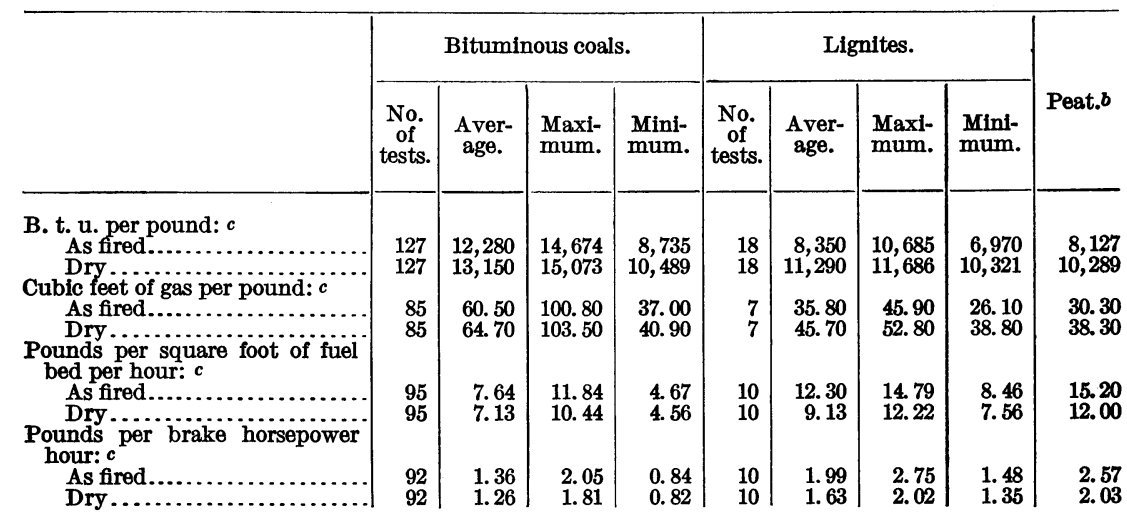

$a$ The term subbituminous has been adopted by the United States Geological Survey for the class of coal generally called "black lignite."

$b$ One sample of peat only.

c 90 to 100 per cent load, 30 to 50 hours. 
Summarized items relating to fuels tested in gas producer at St. Louis, Mo., and Norfolk, Va.-Continued.

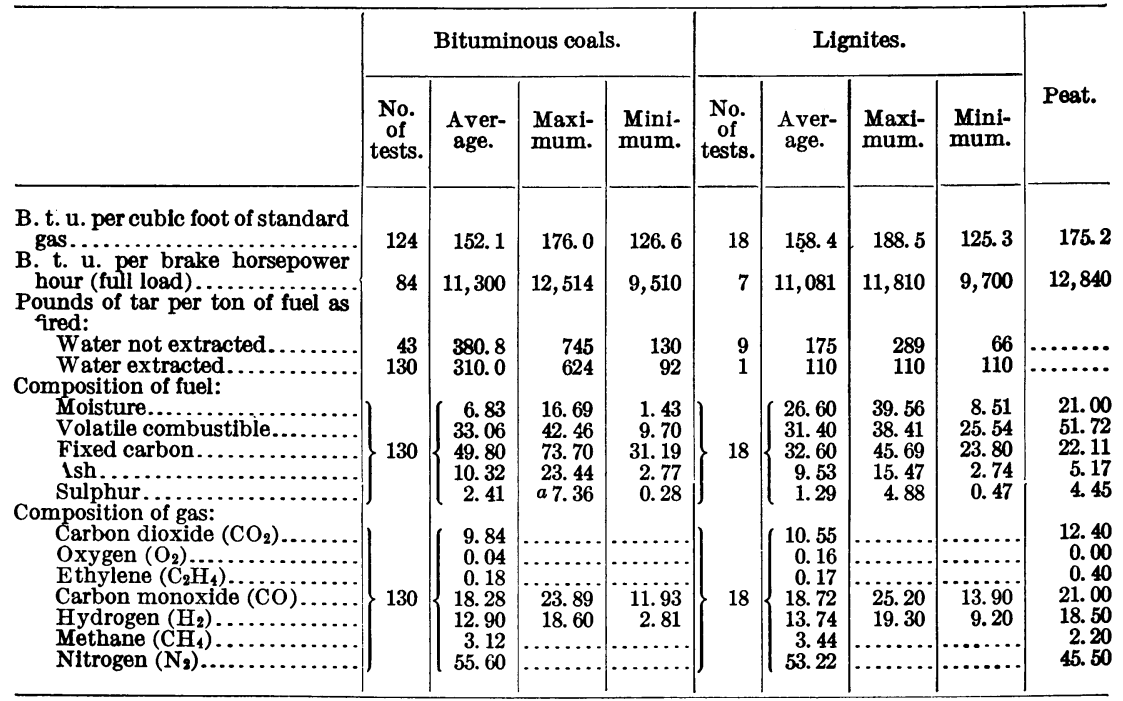

a A mixture of California lignite and cinders contained 8.1 per cent of sulphur.

The results of these tests, as given in the accompanying table, have been subjected to absolutely no refinements. With the possible exception of two or three coals, only one test has been made on each sample, and the result of each test has, to a great extent, depended on the ability of the producer operator to become familiar with the method of handling a given coal during a period of eight or ten hours preceding the official test.

It should also be borne in mind that all the tests, whether on bituminous coal, lignite, or peat, have been made in a producer of one size and type-a type designed primarily for use with anthracite coal-and that it has been imperative that the test be made and the required power generated without regard to the proper relations between the gas-producing quelities of the coal and the fuel-bed area. The tests have been conducted under the restrictions of steady load on the engine (235 brake horsepower), and not with a view to determining the maximum power-producing quality of the coal. Despite this restriction the general conclusions are regarded as sufficiently significant for presentation, although they may be modified by later investigations. 
PRODUCER-GAS TESTS.

Summary of results of producer-gas tests at St. Louis and Norfolk.

\begin{tabular}{|c|c|c|c|c|c|c|c|c|c|}
\hline \multirow{3}{*}{ Name of sample. } & \multirow{3}{*}{ Location of mine. } & \multirow{3}{*}{$\begin{array}{l}\text { Size or condi- } \\
\text { tion. }\end{array}$} & \multirow{3}{*}{ 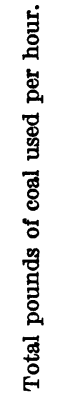 } & \multicolumn{2}{|c|}{$\begin{array}{l}\text { British ther- } \\
\text { mal units. }\end{array}$} & \multicolumn{4}{|c|}{$\begin{array}{l}\text { Total pounds of coal } \\
\text { as fired per hour. }\end{array}$} \\
\hline & & & & \multirow{2}{*}{ 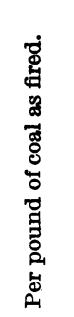 } & \multirow{2}{*}{ 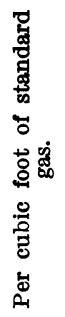 } & \multicolumn{2}{|c|}{$\begin{array}{l}\text { Per electric } \\
\text { al horse- } \\
\text { power. }\end{array}$} & \multicolumn{2}{|c|}{$\begin{array}{l}\text { Per brake } \\
\text { horse- } \\
\text { power. }\end{array}$} \\
\hline & & & & & & 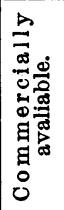 & 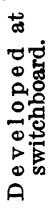 & 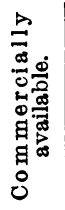 & 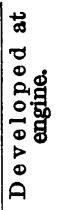 \\
\hline & & UII & 341.4 & 12,865 & 149.2 & 1.77 & 1.71 & 1.51 & 1.45 \\
\hline & & Run & 265.2 & 12 , & 152.0 & 1.45 & & 1.23 & 1. 16 \\
\hline & & 1 & 196.6 & 14,170 & 143.7 & $\begin{array}{l}1.02 \\
.02\end{array}$ & & .87 & \\
\hline & & & 230.5 & 12,773 & 125.5 & 2.24 & & 1.90 & \\
\hline & & Lin & 358.1 & 12 , & & 2.13 & & 1.81 & \\
\hline & & $\mathrm{Lu}$ & 523.4 & 6,356 & 12 & 4.41 & 4.07 & 3.75 & 3. \\
\hline B & & $\mathrm{Ru}$ & 369.2 & 9 & & 2.88 & & 2.45 & \\
\hline & & & 597.3 & & & & & 2. $c 0$ & \\
\hline & & Lu & 428.4 & 9,7 & & 2.30 & 2. 14 & 1.95 & \\
\hline & & $\mathrm{Br}$ & 620.6 & 8,1 & & & & 2.69 & \\
\hline Illin & Mario & $\mathrm{Ru}$ & 386.0 & 12, & & & & 1.70 & \\
\hline & & & 398.2 & 11 , & 151 & 2.11 & & 1.79 & 1.7 \\
\hline & & & 418.2 & 10 , & & & & 1.82 & 1.7 \\
\hline Illin & bli & $\frac{1}{2}$-in & 683.8 & 9, & & 5.25 & & 4.46 & 4. \\
\hline & & & 492.1 & 9, & & & & & \\
\hline & & Sla & 508.5 & 9 & & 3. 12 & & 2.65 & 0 \\
\hline $\operatorname{lin}$ & Paisley & $\mathrm{Nu}$ & 411.5 & 10, & 147 & 2. & & 1.77 & \\
\hline Illin & & & 418. 1 & & & & & 1.79 & 1. \\
\hline & & Sla & 329 & 11, & & & & 1.44 & 1. \\
\hline Illin & Carte & Egg & 305. & 12, & & 1. & 1. & 1.33 & \\
\hline & & $5 \mathrm{w}$ & 595 & 10 & & & & 3.13 & \\
\hline & & $3 \mathrm{w}$ & 277 & 12 , & & & & $\begin{array}{l}.25 \\
1.25\end{array}$ & 1. \\
\hline & & ..... do & 277.7 & 12, & & 1. 46 & & 1.24 & \\
\hline Illin & & $\mathrm{Egg}$ & 362.6 & 11 , & & 1.84 & & 1.56 & \\
\hline Illin & & & 356 . & & & & & 1.61 & \\
\hline Illin & C & $\boldsymbol{L}$ & 360 & 10 , & & & & 1.63 & \\
\hline & $\mathrm{H}$ & ... & & & & & & 1. & \\
\hline Illi & & & & & & & & 1.57 & .4 \\
\hline Illin & Zei & 3 -in & 294 & 11 , & & & & 1.32 & \\
\hline & & Run & 3 & 11, & & & & 2.04 & 1. \\
\hline & $\mathrm{Tr}$ & & 3 & 10 , & & 2. & & 1.85 & 1. \\
\hline & $\mathrm{Ne}$ & & 0 & 10 , & & & & 1.39 & \\
\hline Illin & Dor & 5 -in & & 10, & & & & 1.71 & \\
\hline & & Slac & 374 & & & 2.17 & & 1.85 & \\
\hline II & $\ddot{\mathbf{M}}$ & Lun & $\begin{array}{l}368 . \\
368 .\end{array}$ & 10, & & 2. & & 1.70 & 1. \\
\hline Illi & & & & & & & & 1.51 & \\
\hline & & $\mathrm{Ri}$ & 348 & & & 2. & & 1.81 & \\
\hline III. & & & 347 & & & 3. & & & \\
\hline & Liv & & & & & 2. & & 1.70 & \\
\hline & & Was & & & & 1. & & & \\
\hline & Mil & Run & 4 & 11 , & & & & 1.96 & 1.8 \\
\hline & Boo & ..... do. & & 11, & & 2. & 2. & 2.0 & \\
\hline & & Nut an & & 11 & & 2. & & 1.78 & \\
\hline Indi & Hyn & Run & & & & & & & \\
\hline & & $\ldots . . d$ & & 11, & & 1. & & 1.37 &. \\
\hline & & $\begin{array}{l}\cdots . .8 \\
\cdots . .8\end{array}$ & & 11, & & 2. & & 1.74 & \\
\hline & Litt & itin & & & & & & & \\
\hline In & Ter & & & 11 , & & 1.7 & & & \\
\hline In & Mac & $11-i$ & & 11 & & 1. & & & \\
\hline In & $\mathrm{Du}$ & & & & & 1. & & 1.56 & \\
\hline In & $\mathrm{Ha}$ & Run of mine. & 364.4 & 11,146 & & 1.97 & & 1.67 & \\
\hline Indians I & Terr & .... do. & & 10,924 & & 2.21 & & 1.88 & \\
\hline & & & & 11,408 & & 1.68 & & 1.43 & \\
\hline Indiana $\mathrm{i}$ & Seel & ...do & 343.4 & 11,146 & 154.1 & 1.91 & & 1.62 & \\
\hline dit & Lin & .. do & & 11,651 & & 1.75 & & 1.48 & 1.4 \\
\hline & & & 302 & 11,651 & & 1.65 & & 1.40 & \\
\hline Indiana No. 16 & & do. & 345.8 & 11,592 & 136.7 & 2.0 & & 1.75 & 1.6 \\
\hline Indiana I & Winslo & Lump. & 30 & 12,031 & & 1.6 & 1. & 1.42 & 1. 3 \\
\hline & & & 351.1 & 11,952 & & 1.88 & & 1.60 & 1.5 \\
\hline Territory & Henryetta.. & is -inch + & 392.7 & 12,787 & 159.2 & 2.00 & 1.92 & 1.71 & 1.6 \\
\hline Indian Territory & Lehigh & - Inc & 312.5 & 10,364 & 161.1 & 1.66 & 1.57 & 1.41 & 1.33 \\
\hline $10 \mathrm{w}$ & & in & 8.4 & 8.735 & 60.2 & 2.19 & 2.07 & 1.86 & .76 \\
\hline
\end{tabular}


Summary of results of producer-gas tests at St. Louis and Norfolk-Continued.

\begin{tabular}{|c|c|c|c|c|c|c|c|c|c|}
\hline \multirow{3}{*}{ Name of sample. } & \multirow[b]{3}{*}{ Location of mine. } & \multirow{3}{*}{$\begin{array}{l}\text { Size or condi- } \\
\text { tion. }\end{array}$} & \multirow{3}{*}{ 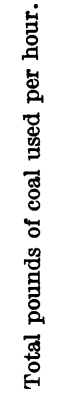 } & \multicolumn{2}{|c|}{$\begin{array}{l}\text { British ther- } \\
\text { mal units. }\end{array}$} & \multicolumn{4}{|c|}{$\begin{array}{l}\text { Total pounds of coal } \\
\text { as fired per hour. }\end{array}$} \\
\hline & & & & \multirow{2}{*}{ 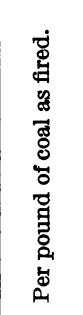 } & \multirow{2}{*}{ 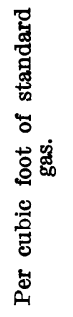 } & \multicolumn{2}{|c|}{$\begin{array}{l}\text { Per electric- } \\
\text { al horse- } \\
\text { power. }\end{array}$} & \multicolumn{2}{|c|}{$\begin{array}{c}\text { Per brake } \\
\text { horse- } \\
\text { power. }\end{array}$} \\
\hline & & & & & & 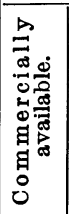 & 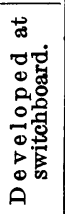 & 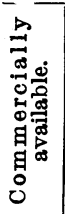 & 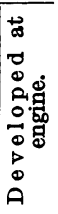 \\
\hline Sas & 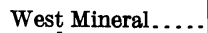 & & 338.4 & 12,836 & 167.2 & 1.76 & 1.69 & 1.50 & 1.44 \\
\hline & & & 325.3 & 12,967 & 128.9 & & & 1.40 & \\
\hline ans & $\mathrm{J}$ & & 349.4 & 11,470 & 155.2 & 1.84 & 1.76 & 1.56 & 1. \\
\hline Ken & Str & & 276.7 & 14,270 & 166.5 & 1.49 & & 1.26 & \\
\hline $\begin{array}{l}\text { Ken } \\
\text { Ken }\end{array}$ & $\begin{array}{l}\text { Earington } \\
\text { Big Black }\end{array}$ & $\begin{array}{l}\text { Run of } 1 \\
\text {..... do. }\end{array}$ & $\begin{array}{l}410.8 \\
274.4\end{array}$ & $\begin{array}{l}12,283 \\
13,984\end{array}$ & $\begin{array}{l}155.9 \\
163.2\end{array}$ & $\begin{array}{l}2.16 \\
1.47\end{array}$ & $\begin{array}{l}2.05 \\
1.39\end{array}$ & $\begin{array}{l}1.86 \\
1.25\end{array}$ & $\begin{array}{l}1.75 \\
1.18\end{array}$ \\
\hline $\mathbf{K}$ & Paintsvill & & 265 & 13,747 & 176.0 & 1.42 & 1.33 & 1.20 & \\
\hline & & & $\begin{array}{l}200.0 \\
322.8\end{array}$ & 11,986 & 153. 7 & 1.75 & 1.65 & 1. 49 & \\
\hline $\begin{array}{l}\text { Miss } \\
\text { Mon }\end{array}$ & Bev & & 384.5 & 10,505 & 140.0 & 2.07 & 1.94 & 1.76 & 1. \\
\hline $\begin{array}{l}\text { Mon } \\
\text { Mon }\end{array}$ & Red & 4 washed & 506.8 & 10,575 & 160.8 & 2.65 & & & \\
\hline & & & 424.6 & 10,478 & 147 & 2.34 & & 1.99 & 1. \\
\hline $\begin{array}{l}\text { Mon } \\
\text { New }\end{array}$ & Brid & & 347.2 & 10,685 & 181 & & & & \\
\hline $\begin{array}{l}\mathrm{Ne} \\
\mathrm{Ne}\end{array}$ & Van & & 275.7 & 11,425 & & & & 1.25 & \\
\hline & Bril & & 287.5 & 12,501 & 13 & 1.62 & 1.52 & & \\
\hline $\begin{array}{l}\mathrm{Ne} \\
\mathrm{No}\end{array}$ & Blo & & 298.1 & 12,542 & & 1.60 & & & \\
\hline & Lehi & & 559.5 & 6,970 & 160 & & & 2.58 & \\
\hline th Dakota No. 2 . & Willi & & 510.0 & 6,802 & 18 & 4.07 & 3.80 & & \\
\hline Do.. & & & 552.1 & 7,3 & & & & & \\
\hline $\begin{array}{l}\text { Do } \\
\text { North Dak }\end{array}$ & $y$ & & 571.6 & 6,739 & 14 & 2. & 2.87 & 2.53 & \\
\hline $\begin{array}{l}\text { North Dako } \\
\text { Ohio No. } 3 .\end{array}$ & & & 632.8 & $\begin{array}{r}7,279 \\
\end{array}$ & 158.9 & 3. 42 & $\begin{array}{l}3.24 \\
1.51\end{array}$ & & \\
\hline Or & $\begin{array}{l}\text { Sna } \\
\text { Bra }\end{array}$ & & $\begin{array}{l}303.4 \\
270.4\end{array}$ & $\begin{array}{l}12,200 \\
13,158\end{array}$ & $\begin{array}{l}156.1 \\
148.8\end{array}$ & $\begin{array}{l}1.62 \\
1.41\end{array}$ & $\begin{array}{l}1.51 \\
1.34\end{array}$ & $\begin{array}{l}1.37 \\
1.20\end{array}$ & 1.2 \\
\hline & & $\mathrm{Nu}$ & $\begin{array}{l}270.4 \\
254.0\end{array}$ & $\begin{array}{l}15,108 \\
13,414\end{array}$ & 15 & 1.34 & $\begin{array}{l}1.04 \\
1.26\end{array}$ & 1.13 & $\begin{array}{l}1.1 \\
1.0\end{array}$ \\
\hline & & & 254.2 & & & & & & \\
\hline & & & 331.0 & 12 , & & & & 1. & \\
\hline & & & 309 & 11 , & & 1. & & & \\
\hline & & Lur & 277.7 & 12 & & & 1. & & \\
\hline & Mi & & 268.7 & 12,8 & & & & & \\
\hline & Fl & & & 12, & & & & & 1. \\
\hline o No. & Bella & of min & 335 & & & & & & \\
\hline D & & & & & & & & & \\
\hline Penn & & & 2 & 13 & & 149 & 1.42 & 1. 27 & \\
\hline No. 5 & Ells & & 2 & 13 , & & & & & \\
\hline Pennsylvania No. 6 . & East Mil & $\mathrm{Ru}$ & 294 & 13 & & & & 1.38 & \\
\hline & & & 238 & 13, & & 1. & 1.23 & 1. 10 & \\
\hline Penn & & & 5 & & & & & & \\
\hline 8 & $\mathrm{El}$ & & 240 & 14 , & & & & 1.15 & 17 \\
\hline & & $\frac{3}{4}-i n$ & & 13 , & & 1. & & 1.18 & 1. \\
\hline & $\mathrm{Ch}$ & $\mathbf{R u}$ & & & & & & & \\
\hline 12 & Ach & . & 240.2 & & & & & 1.09 & 1. \\
\hline Penn & Crei & & & & & & & & \\
\hline & & & & & & & & 1.16 & \\
\hline Penn & & & & & & & & & 1. \\
\hline & & & 223 & & & & & & \\
\hline $\mathrm{Pe}$ & & & 279 & & & 1. & 1.49 & 1.31 & \\
\hline No.22 & $\mathrm{Hu}$ & & & & & 1.31 & & 1.11 & \\
\hline & & & 262 & & & & 1.56 & & \\
\hline Te & Gat & & & & 167.9 & 1. & 1.24 & 1.11 & \\
\hline & & & & & & & & & \\
\hline & Oli & & 263.9 & & & & & 1.31 & 1. \\
\hline & & & 2 & 13 & & 1. & & & \\
\hline & & & 291.2 & & & 2. & 1.87 & 1.72 & \\
\hline Ter & Wi & & 313.6 & 12, & & 1.74 & & 1.48 & \\
\hline Tenn & Clift & & 243.9 & 13,471 & 147 & & & & \\
\hline Do.. & & & 291.3 & 13,459 & 157.5 & 1.58 & 1.48 & 1.34 & \\
\hline Texas ? & Croc & & 660.0 & & & & & & \\
\hline & & & 519.5 & 7,348 & & 2. & & 2.33 & 2. \\
\hline & Olsen $a$ & & 549.4 & 7,603 & 171.8 & 2.90 & 2.75 & 2.47 & 2. \\
\hline & & & 529.8 & & 156.1 & & 2.74 & 2.43 & \\
\hline & & & 302.0 & 13,212 & 171.4 & 1. & & 1.31 & 1. \\
\hline Vir & $\mathrm{Cr}$ & & 300.2 & 13,324 & 164.4 & 1.61 & 1.53 & & \\
\hline & & $\mathrm{Ru}$ & 272.7 & & & 1. & & 1. 25 & 1. 1 \\
\hline Virgi & Toms Cree & Lum & 236.7 & 14,643 & 156.4 & 1.2 & 1.21 & 1.10 & \\
\hline Virgin & Darby & & 257.0 & 14,470 & & 1.38 & 1.3 & & \\
\hline
\end{tabular}


Summary of results of producer-gas tests at St. Louis and Norfolk-Continued.

\begin{tabular}{|c|c|c|c|c|c|c|c|c|c|}
\hline \multirow{3}{*}{ Name of sample. } & \multirow{3}{*}{ Location of mine. } & \multirow{3}{*}{$\begin{array}{l}\text { Size or condi- } \\
\text { tion. }\end{array}$} & \multirow{3}{*}{ 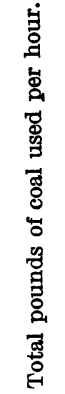 } & \multicolumn{2}{|c|}{$\begin{array}{l}\text { British ther- } \\
\text { mal units. }\end{array}$} & \multicolumn{4}{|c|}{$\begin{array}{l}\text { Total pounds of coal } \\
\text { as fired per hour. }\end{array}$} \\
\hline & & & & \multirow{2}{*}{ 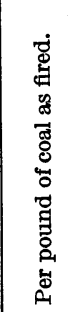 } & \multirow{2}{*}{ 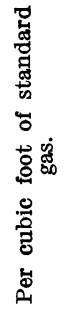 } & \multicolumn{2}{|c|}{$\begin{array}{l}\text { Per electric- } \\
\text { al horse- } \\
\text { power. }\end{array}$} & \multicolumn{2}{|c|}{$\begin{array}{c}\text { Per brake } \\
\text { horse- } \\
\text { power. }\end{array}$} \\
\hline & & & & & & 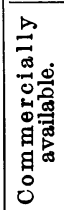 & 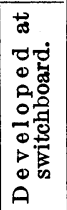 & 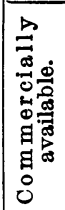 & 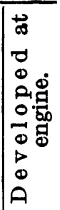 \\
\hline irg & & & 287. & 59 & 160.7 & 1.49 & & 1.27 & .22 \\
\hline & & & & & & & & & \\
\hline $\begin{array}{l}\text { Virginia (J a m e s- } \\
\text { town No. 1). }\end{array}$ & Vir & & 300 & 12, & 15 & $\begin{array}{l}1.29 \\
1.52\end{array}$ & 48 & $\begin{array}{l}1.09 \\
1.29\end{array}$ & \\
\hline Washington No. $1 .$. & Rent & & 496. & & 14 & 3. & 3.44 & & \\
\hline $\begin{array}{l}\cdots \\
\cdots\end{array}$ & & & 440. & & & & & & \\
\hline Washir & & $\dddot{\mathrm{Lu}}$ & $\begin{array}{l}506 \\
281\end{array}$ & $\begin{array}{r}9, \\
12\end{array}$ & 16 & & $\begin{array}{l}9 \\
4\end{array}$ & $\begin{array}{l}2.32 \\
1.29\end{array}$ & \\
\hline Wes & K & $\mathrm{Ru}$ & 320 & 14, & 14 & $\begin{array}{l}1.02 \\
1.69\end{array}$ & & $\begin{array}{l}1.29 \\
1.43\end{array}$ & 1. \\
\hline Wes & $\mathrm{B}_{1}$ & & 262 & 13 & & & & & \\
\hline & & & 299 & & & & & & \\
\hline We & & $\cdots$ & 364 & $\begin{array}{l}14 \\
14\end{array}$ & 15 & 1. & 1. & $\begin{array}{l}1.00 \\
1.63\end{array}$ & 1. \\
\hline $\begin{array}{l}\text { West Virgi } \\
\text { Do... }\end{array}$ & $\mathrm{P}$ & ... & 328. & 14, & 15 & 1.76 & 1. & 1.49 & 1. \\
\hline West Virginia No. & $\dddot{\mathrm{Big}}$ & - & $\begin{array}{l}284 \\
304\end{array}$ & $\begin{array}{l}14,2 \\
14,6\end{array}$ & $\begin{array}{l}160 \\
142\end{array}$ & $\begin{array}{l}1.51 \\
1.59\end{array}$ & 1.53 & $\begin{array}{l}1.28 \\
1.35\end{array}$ & 1.2 \\
\hline West Virginia No. & Page & do & 208.0 & 14,674 & 139.2 & 1. 10 & 1.04 & 0.93 & 0.88 \\
\hline $\begin{array}{l}\text { West Virginia No. } \\
14 .\end{array}$ & & .....do. & 220.6 & 14,488 & 147.0 & 1.15 & 1.10 & .98 & .9 \\
\hline West Virginia No. & Mor & Nut & 277.5 & 13,882 & 156.1 & 1. 49 & 1.40 & 1.26 & 1.19 \\
\hline $\begin{array}{l}\text { West Virginia No. } \\
18 .\end{array}$ & Glen Alum & Run of mine & 238.0 & 14,152 & 158.9 & 1. 27 & 1.20 & 1.08 & 1.02 \\
\hline West Virginia No. & Ac & 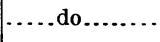 & 257.3 & 13,948 & 156.3 & 1.39 & 1.31 & 1.18 & 1.11 \\
\hline $\begin{array}{l}\text { West Virginia No. } \\
25 .\end{array}$ & C & I & 273.0 & 13,288 & 171.6 & 1. 42 & 1. 37 & 1. 21 & 1.17 \\
\hline $\begin{array}{l}\text { West V i r g i n i a } \\
\text { (Jamestown No.3) }\end{array}$ & Davy. & Run of mine & 261.2 & 14,420 & 138.5 & 1.34 & 1.30 & 1.14 & 1.11 \\
\hline $\begin{array}{l}\text { West V i r g i n i a } \\
\text { (Jamestown No.4) }\end{array}$ & Rush Ru & $\ldots . . . \mathrm{do}$ & 246.3 & 14,636 & 150.0 & 1. 25 & 1.21 & 1.06 & 1.03 \\
\hline $\begin{array}{c}\text { West V i r g in i a } \\
\text { (Jamestown No.5) }\end{array}$ & Sew & d & 237.2 & 14,333 & 152.5 & 1. 22 & 1.19 & 1.04 & 1. \\
\hline $\begin{array}{l}\text { West V i r g i n i a } \\
\text { (Jamestown No.7) }\end{array}$ & De & dr & 260.4 & 14,665 & 152.3 & 1.37 & 1.33 & 1.16 & 1.13 \\
\hline Do.................... & & 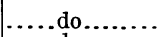 & 243.9 & 14,665 & 154.1 & 1.25 & 1. & 1.06 & 1.04 \\
\hline Wyoming No. 2. & Camb & & 459.8 & 9,650 & 151.0 & 2. 49 & 2. & 2.11 & 1.9 \\
\hline Wyo & Alad & $\cdots . . . d$ & 394 & 9 , & & $\begin{array}{l}2.40 \\
2.19\end{array}$ & 2. & 1.86 & 1. \\
\hline Wyol & & & 438.2 & 10 & & & & 2. 02 & 1. \\
\hline Wyoming No. 6 & Kemmerer & $\ldots . . d c$ & 474.9 & 10,460 & 171.8 & 2. 52 & 2. 38 & 2.14 & 2.02 \\
\hline
\end{tabular}

\section{RELATIVE RESULTS OF STEAM AND PRODUCER-GAS TESTS.}

In considering the relation between the economic results of plants of the two types under discussion, namely, steam and producer-gas, the fact should be remembered that to-day, in the ordinary manufacturing plant operated by steam power, less than 5 per cent of the total energy in the fuel consumed is available for useful work at the machine.

In that connection it is of interest and value to glance at the possibilities of the best designed and most skillfully operated commercial plant now in use. The data concerning the steam plant selected for 
this determination are derived from a table prepared by Mr. Stott, superintendent of motive power, Interborough Rapid Transit Company, New York City, which, as Mr. Stott says, ${ }^{a}$ shows "the losses found in a year's operation of what is probably one of the most efficient plants in existence to-day, and, therefore, typical of the present state of the art."

Average losses in steam plant of the Interborough Company in converting 1 pound of coal, containing 12,500 British thermal units, into electricity.

\begin{tabular}{|c|c|c|}
\hline & $\begin{array}{c}\text { British } \\
\text { thermal } \\
\text { units. }\end{array}$ & Per cent. \\
\hline 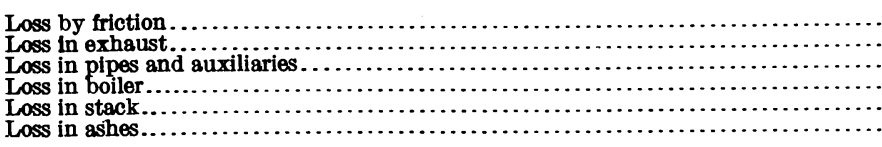 & $\begin{array}{r}138 \\
7,513 \\
275 \\
1,000 \\
1,987 \\
300 \\
\end{array}$ & $\begin{array}{r}1.1 \\
60.1 \\
2.2 \\
8.0 \\
1.9 \\
2.4 \\
\end{array}$ \\
\hline \multirow[t]{2}{*}{ 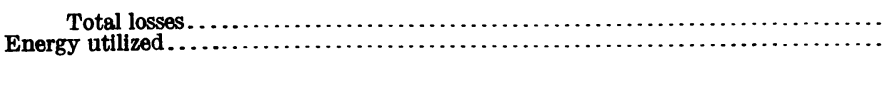 } & $\begin{array}{r}11,213 \\
1,287 \\
\end{array}$ & $\begin{array}{l}89.7 \\
10.3 \\
\end{array}$ \\
\hline & 12,500 & 100.0 \\
\hline
\end{tabular}

Mr. Stott further presents a table showing the thermal efficiency of producer-gas plants, concerning which he says:

The following heat balance is believed to represent the best results obtained in Europe and the United States up to date in the formation and utilization of producer gas.

Average losses in a producer-gas plant in the conversion of 1 pound of coal, containing 12,500 British thermal units, into electricity.

\begin{tabular}{|c|c|c|}
\hline 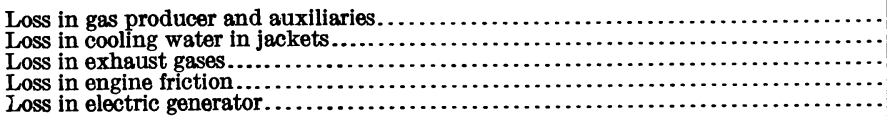 & $\begin{array}{r}2,500 \\
2,375 \\
\mathbf{3}, 750 \\
813 \\
62\end{array}$ & $\begin{array}{r}20.0 \\
19.0 \\
30.0 \\
6.5 \\
.5\end{array}$ \\
\hline 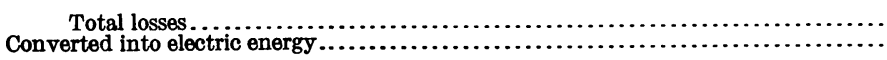 & $\begin{array}{l}9,500 \\
3,000\end{array}$ & $\begin{array}{l}\text { 76. } 0 \\
24.0\end{array}$ \\
\hline & 12,500 & 100.0 \\
\hline
\end{tabular}

The thermal efficiency of such plants, as given by different writers, runs as high as 33,36 , and 38.5 per cent, and for some plants figures as extravagant as "above 40 " are boldly published. Although the present aim has been to give figures for a producer-gas plant that may compare favorably with those of the steam plant of the Interborough Company, an effort has been made to keep well within obtainable efficiencies. Attention is also directed to the fact that 
the producer-gas pant considered should be large enough to compare favorably with the steam plant. This precludes comparisons with suction plants, which are relatively small but give higher proportional efficiencies than the larger pressure and down-draft plants, for these require more or less auxiliary apparatus.

Mr. Stott seems ready to accept a thermal efficiency of 24 per cent for the best producer-gas plants for comparison with 10.3 per cent efficiency for his steam plant, but a careful study of the problem has led to a more conservative estimate for the producer-gas plant, namely, 21.5 per cent.

The tables just given show the comparative efficiencies reached in plants of the best type, both steam and producer-gas, but these are seldom realized in common practice. The results obtained in the government plant at St. Louis are probably more nearly representative of the ordinary type of apparatus. These results are as follows:

Relative economies of steam and gas power plants at St. Louis in the conversion of 1 pound of coal containing 12,500 British thermal units into electricity.

\begin{tabular}{|c|c|c|c|c|}
\hline & \multicolumn{2}{|c|}{ Steam power. } & \multicolumn{2}{|c|}{ Gas power. } \\
\hline & $\begin{array}{c}\text { British } \\
\text { thermal } \\
\text { units. }\end{array}$ & Per cent. & $\begin{array}{c}\text { British } \\
\text { thermal } \\
\text { units. }\end{array}$ & Per cent. \\
\hline \multirow[t]{2}{*}{ 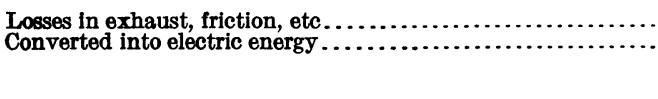 } & $\begin{array}{r}11,892 \\
608\end{array}$ & $\begin{array}{r}95.14 \\
4.86\end{array}$ & $\begin{array}{r}10,812 \\
1,688\end{array}$ & $\begin{array}{l}86.5 \\
13.5\end{array}$ \\
\hline & 12,500 & 100.00 & 12,500 & 100.0 \\
\hline
\end{tabular}

The following table shows the comparative results obtained at St. Louis from 75 bituminous coals and 6 lignites used in the gas producer and under the steam boiler:

Total pounds of coal as fired per electrical horsepower per hour developed at the switchboard, for both steam and producer-gas plants.

\begin{tabular}{|c|c|c|c|c|}
\hline Fuel used. & Locality. & Steam. & $\begin{array}{c}\text { Producer } \\
\text { gas. }\end{array}$ & Ratio. \\
\hline 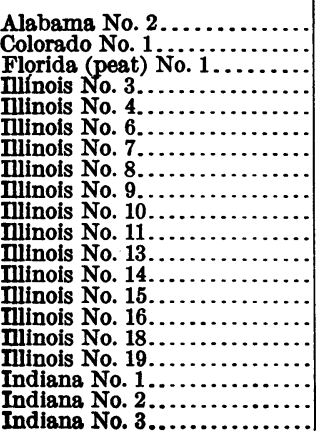 & 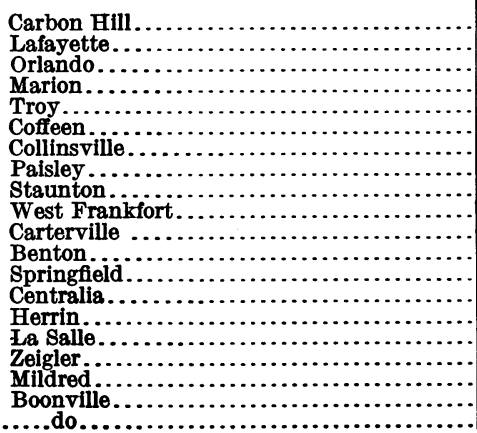 & $\begin{array}{r}4.29 \\
6.04 \\
4.74 \\
5.47 \\
6.28 \\
5.21 \\
6.26 \\
5.22 \\
4.88 \\
4.35 \\
4.17 \\
5.27 \\
4.61 \\
4.24 \\
4.53 \\
4.09 \\
4.95 \\
4.78 \\
4.92\end{array}$ & $\begin{array}{l}1.71 \\
2.14 \\
3.03 \\
1.93 \\
2.01 \\
2.02 \\
2.41 \\
1.98 \\
2.01 \\
1.59 \\
1.37 \\
1.74 \\
1.79 \\
1.80 \\
1.81 \\
1.74 \\
1.47 \\
2.17 \\
1.68 \\
1.97\end{array}$ & $\begin{array}{r}2.51 \\
2.82 \\
\cdots \\
2.46 \\
2.72 \\
3.11 \\
2.16 \\
3.16 \\
2.59 \\
3.07 \\
3.18\end{array}$ \\
\hline
\end{tabular}


Total pounds of coal as fired per electrical horsepower per hour developed at the switchboard, for both steam and producer-gas plants-Continued.

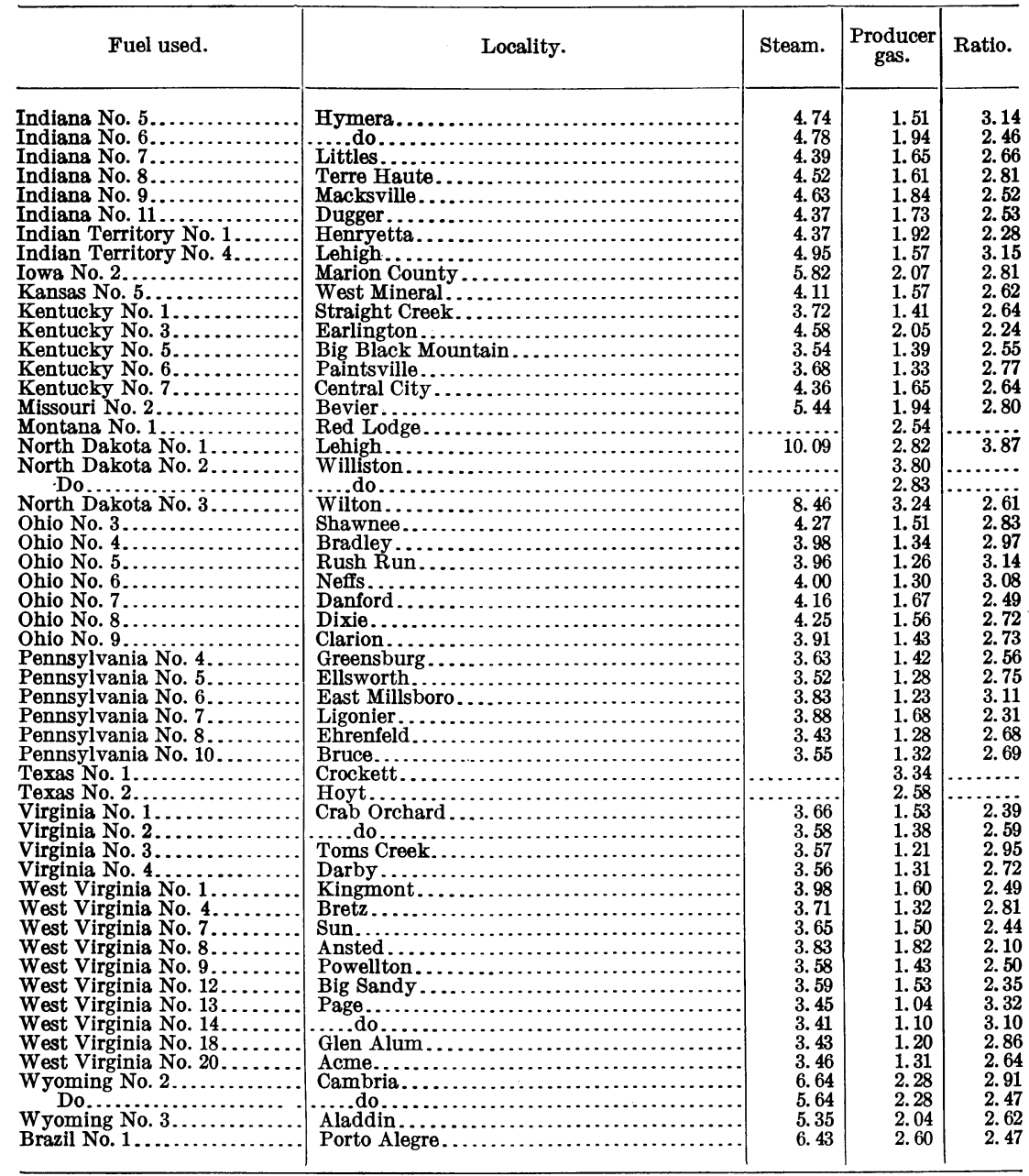

Especial attention is called to the fact that several low-grade coals and lignites that have proved of little value or even worthless under the steam boiler have given excellent results in the gas producer.

The ratios of the total fuel per brake-horsepower hour required by the steam plant and producer-gas plant, under full load, not counting stand-by losses, are presented below as derived from 75 coals, 6 lignites, and 1 peat (Florida). 
Ratios of fuel used in steam and gas plants.

Average ratio, coal as fired per brake-horsepower hour under boiler to coal as fired per brake-horsepower hour in producer.........................

Maximum ratio, coal as fired per brake-horsepower hour under boiler to coal as fired per brake-horsepower hour in producer........................

Minimum ratio, coal as fired per brake-horsepower hour under boiler to coal as fired per brake-horsepower hour in producer.........................

Average ratio, lignite and subbituminous coal as fired per brake-horsepower hour under boiler to lignite as fired per brake-horsepower hour in producer. .

Maximum ratio, lignite and subbituminous coal as fired per brake-horsepower hour under boiler to lignite as fired per brake-horsepower hour in producer..

Minimum ratio, lignite and subbituminous coal as fired per brake-horsepower hour under boiler to lignite as fired per brake-horsepower hour in producer..

Average ratio, peat as fired per brake-horsepower hour under boiler to peat as fired per brake-horsepower hour in producer........................

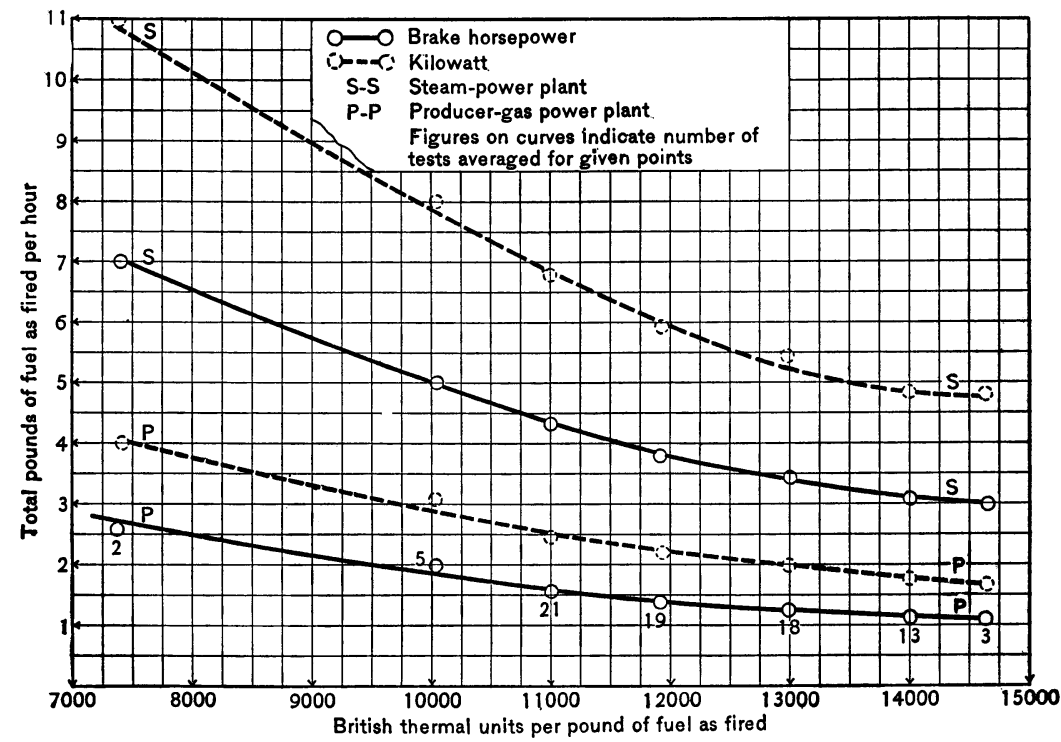

Figure 1.-Comparative service of coals and lignites in gas-producer and steam-boller plants.

The figures for the producer-gas tests include not only the coal consumed in the gas producer, but also the coal used in the auxiliary boiler for generating the steam necessary for the pressure blastthat is, the figures given include the total coal required by the gasproducer plant.

The curves in figure 1 show graphically the great economy secured from the 75 bituminous coals and 6 lignites when used in the gas producer instead of under the steam boiler. The results of the tests are officially reported on the basis of switchboard horsepower, but in order that they may be of more practical value they are given here on the basis of brake horsepower and kilowatts-the efficiency of electric generator and belt in each plant being assumed as 85 per cont.

$68942^{\circ}-$ Bull. $9-10-2$ 
In the above comparisons between the steam and producer-gas plants no consideration has been made of stand-by losses. The result for each plant has been derived from experiments made during continuous operation for a given period. Data on stand-by losses for plants operated during a portion of each 24-hour day are not at present obtainable at the fuel-testing plant. Very few results of experiments relating to this point have been published, and opinions regarding the amount of fuel required for holding fires over night or during idle periods in both boiler and producer plants seem to differ widely.

In considering the possible increase in efficiency of the steam tests with a compound engine, as compared with the simple engine used, the fact should not be overlooked that a corresponding increase in the efficiency of the producer-gas tests may be brought about under corresponding favorable conditions. Not only is the producer passing through a transitional period, but the gas engine must still be regarded in the same light. In the larger sizes the vertical singleacting engine is being replaced by the horizontal double-acting engine. Other changes and improvements are constantly being made which tend to increase the efficiency of the gas engine, as compounding and tripling the expansions have already increased the efficiency of the steam engine.

As has already been stated, the gas engine used in the tests here reported is of a type that is rapidly becoming obsolete for this size, namely, the vertical, three-cylinder, single-acting.

A brief consideration of these points will lead at once to the conclusions that a comparison of the producer-gas plant and steam plant used in these tests is very favorable to the former, and that any increase in efficiency in the steam tests that might result from using a compound engine can be offset by the introduction of a gas engine of more modern type and a producer plant designed to handle the special kinds of fuel used.

It should be noted that many fuels which give poor results under steam boilers have been used with great ease and efficiency in the gas producer, which thus makes it possible to utilize low-grade coals and lignites that have heretofore been regarded as practically useless. Several of the poorest grades of bituminous coals have shown remarkable efficiency in the gas producer, and lignites and peat have been used in it with great facility, thus opening the way to the introduction of cheap power into large districts that have thus far been commercially unimportant owing to lack of industrial opportunities. Experiments with "bone," a refuse product in bituminouscoal mining, have given excellent results, showing an efficiency in the producer equal to that reached by good steam coal under boilers. Recent investigations with other low-grade fuels, such as mine roof 
slabs, culm, and washery refuse, have also demonstrated the possibility of using such material to advantage in the producer under proper commercial conditions.

\section{EFFICIENCIES.}

It has not been the aim of the testing plant to determine the lowest possible amounts of coal.that could produce a given amount of power or to determine the highest possible efficiency of the particular producer plant installed. By an act of Congress, the work of the plant was restricted to the determination of the possibilities of utilizing bituminous coals, lignites, and other fuels for the production of power. In spite of the fact that no series of runs has been made on any one coal for determining the best possible results obtainable, it is nevertheless gratifying to report that official records show that as small an amount of dry coal as 0.95 pound per hour has been burned in the producer per electrical horsepower developed at the switchboard; or 0.80 pound of dry coal per hour has been burned in the producer per brake horsepower per hour, on the basis of an efficiency of 85 per cent for generator and belt.

\section{VIEWS OF MANUFACTURERS OF PRODUCER-GAS POWER PLANTS.}

In order to determine as exactly as possible the present status of the producer-gas business, an effort has been made to ascertain the point of view of both the manufacturers and the owners and operators of existing plants. With this object the following question was addressed to several manufacturers of gas producers in 1906, and the same question was again submitted to them in May, 1909.

To what extent is the demand for gas engines and gas producers and the interest in the same growing?

It is instructive as well as interesting to review the first replies with those received three years later. The following are those received in 1906:

1. We believe there is a waiting and almost unlimited demand for producer power plants as soon as the manufacturers have something definite to offer and can guarantee quick installation and certain results.

2. The demand for gas engines and gas producers is growing considerably. We have this month closed for an 8,000-horsepower gas-producer plant, and have on our book negotiations pending for over 200,000 horsepower.

3. The demand for gas engines and gas producers is at present apparently only limited by the output, we ourselves having orders way ahead and all the business we can possibly fill. Were we to go out after business we would immediately swamp the factory. These plants are giving such excellent results in the field that they are bound to replace steam for almost all uses, and in consequence the field may be said to be almost unlimited. 
4. The demand for gas producers and the interest manifested in them seems to be growing very rapidly, as indicated by the number of inquiries received at our office and by our agents in different parts of the country.

5. According to inquiries which we are constantly receiving we judge that the interest in the question of gas producers and gas engines is growing considerably, and all indications lead us to believe that the proposition to install gas-power plants will be a very important one in this country before long.

6. Our correspondence indicates a continually growing demand for gas producers for power purposes, especially those adapted for running on soft coals.

7. There has probably never been a mechanical production more widely or thoroughly advertised at such an early period of its history in this country as the suction producer-gas power equipment. Much of this advertising has aroused curiosity among people, many of whom are not contemplating a purchase. On the other hand, the fuel economy is so remarkable that manufacturers with a reputation for reliable goods and with the fuel guaranties they offer, backed by unquestioned responsibility, are able to sell their product with very little effort.

8. The gas-producer business and the uses to which they have been applied have increased about 50 per cent within the last ten years, and are still growing. We should imagine that the next ten years would show a far greater improvement. We think producer gas is yet in its infancy as to various applications.

9. The demand for gas engines and gas producers is growing in that field where the price of coal is highest, and for that reason any commercial tests in suitable gas producers which will use the fuel of the district will be of value.

10. There is no doubt that the gas engine itself is nowadays in such a state of perfection that its use is bound to become general for power production as soon as the possibility of using bituminous coal to a large extent has been proved.

The following replies indicate the views of manufacturers in 1909:

1. It is quite certain that not only the interest in producer-gas power in this country is still growing, but the actual plants being installed are very markedly increasing both in number and size and variety of service. This has resulted in a great stimulus for this type of producer plant by some of the largest and most conservative users of power in the country, such as the public-service corporations.

2. Our experience is that the demand for gas engines and gas producers is showing a logical growth. In the small and medium-sized plants the particularly high efficiency compared with steam-plant operation makes the field for this class of apparatus very large, and a great deal of it is being bought. In large plants, involving the use of units say above 500 kilowatts, the general economic superiority of plants of this class is not so heavy, although there are special cases where large gas engines are of great economic value.

3. There is a decided growth when used for power purposes only and where factory heating is not an essential factor, also where producer gas is used for furnace purposes. Producer gas is rapidly being adopted for power and fuel purposes, while steam is usually installed (at present prices of coal) for power and heating.

4. We find the demand for gas engines increasing very rapidly, having sold more engines since the first of the year than we had in any two years previous. Our shop at present is well filled with orders. The inquiries for producer plants are coming in very rapidly since the gas producer has been brought up to its present state of perfection.

5. It appears that the demand for equipment of this character has kept up in spite of the recent financial depression and business reaction. This should be interpreted as an increase in the interest in the fuel economy usually obtainable in this class of machines.

6. Strongly. Can take orders in only one or two sizes for anything under eight monthe' delivery. 
7. We believe that the demand for gas engines and gas producers is considerably increased, both in the large and small installations. This is evidenced by the fact that there are a number of builders of good anthracite suction producers who find considerable business in the small units, while we have received many duplicate orders for additional units, showing the tendency is to favor the gas producer and gas engine in central power-plant work.

8. From inquiries we are daily receiving for producer-gas power plants, it certainly looks as though power users are beginning to realize the advantages in a producer-gas plant, and our opinion is that the producer is going to make a very rapid stride within a year or so.

9. By the inquiries received by us and the requests for information and for quotations on power equipment as well as by sales actually made, we would judge that the interest and demand for gas engines and gas producers is growing very rapidly. There is further an inclination on the part of the larger power users to consider this type of prime mover that was not apparent two or three years ago. Formerly the majority of our inquiries were for producers ranging from 25 to 100 horsepower capacity. This year's business has been made up very largely of producer equipment ranging from 200 horsepower upward. We take this as an indication that considerable of the doubt previously entertained by the general public as to the reliability of producer-gas equipment has been eliminated, and that power users are having increased confidence in this sort of equipment.

10. The general interest in gas engines and producer-gas power plants is constantly growing, judging from the increasing number of inquiries which we have been receiving during the past year regarding this type of apparatus. This interest is aroused, doubtless, by the advertising of gas-engine builders and the large number of articles written. We believe that the demand for gas engines and producers is growing likewise, as more and more of them are installed for all classes of service, and their reliability and economy under actual working conditions are proved after several years of operation. We do not, however, believe, as some manufacturers seem to do, that the gas power plant is bound to replace nearly every steam installation. Local conditions often make it considerably cheaper to install a noncondensing Corliss engine rather than a gas engine. Considerable difficulty is also experienced in obtaining competent gas-engine operators for anything like a reasonable salary, owing to the newness of the gas-engine field.

When the former inquiry was sent out the manufacturers were also asked:

What are the serious difficulties in the way of more rapid development of gas producers and gas engines as a means of developing power?

A summary of the replies received in 1906 would indicate the difficulties, as viewed by the manufacturers at that time, to be about as follows:

1. The fact that the gas engine is not yet so reliable as the steam engine.

2. The lack of engineers who know how to run producer-gas power plants.

3. Inexperienced salesmen-men not familiar with the details of the engines and producers they are handling.

4. The large number of unsuccessful and only partly successful installations made during the experimental period of this development.

5. Lack of proper design and construction of producer-gas engines in the United States.

6. Lack of knowledge and confidence on the part of the public.

7. The fact that the heating of factory buildings must be provided for by a heating plant separate from the power plant. 
8. Lack of types of producers which will gasify bituminous coal satisfactorily.

9. Inability to use cheap fuels in the suction gas producer.

10. Lack of complete knowledge as to how successfully the various fuels in different localities can be used in gas systems.

11. Large excess cost of gas-engine and gas-producer power plants over that of steam power plants.

The difficulties in 1909 are expressed as follows by manufacturers in replies received from them:

1. Skepticism as to the reliability of gas engines and producers, one-half of the skeptics being against the producer and the other against the engine.

2. Large engines of long stroke become disproportionately high in price, and in the very large installations their availability is not so evident unless fuel is very expensive. Furthermore, the absence of large overload capacity detracts from the flexibility of operation so commonly experienced with steam plants, which may be forced from 50 per cent to 100 per cent above rating. The gas engine and the producer have their particular application and are not a universal panacea for all our previous ills.

3. Lack of confidence in either producer or engine, due to minor defects in either, which makers do not rectify after plants are sold.

4. The chief drawback to the suction hard-coal producer development seems to be the failure of some installations, due not to any faulty construction and design, but to the disinclination on the part of the attendant to properly operate the plant or to learn how to do so. A satisfactory suction soft-coal producer would be a great boon to the gas engine and producer business. The tar, of course, is the main trouble in this case.

5 . None-except education of the general public.

6. The most serious difficulty is the constant entering of new manufacturers into the field. These very often lack the experience necessary to build apparatus that will insure successful operation in central power plant work. We believe it is the size of unit more than anything else.

7. The fact that the average producer builders rate their producers too high, and are not able to instruct their customers to operate the plant properly.

8. The most serious trouble lies in the difficulty of educating the general public, and more particularly engineers to whose hands the laying out of gas-power equipment is usually intrusted, to appreciate fully the requirements of such installations. Most failures are due to lack of appreciation on the part of manufacturers, as well as on the part of power users and consulting engineers, of the importance of small details of the general arrangement of the plant.

9. To our mind, the most serious difficulty in the way of more rapid development of the producer-gas power plant is the difficulty in obtaining a satisfactory producer which will use practically all grades of American bituminous coal, and which at the same time will not be much more expensive than the ordinary anthracite producer plant.

10. The summary of replies (for 1906) very nearly expresses the condition as to the gas producer at the present time, though I would say relative to the engine itself, the record of the engine which we have and its running indicate trouble only with the producer of the electrical outfit during the last three or four months.

Summary No. 7 (for 1906) is to my mind the greatest lack which we have in the introduction of the producer-gas engine. I do not doubt but that this could easily be taken care of, if it has not been up to the present time.

In regard to No. 8 (for 1906), we have not tried bituminous producers and therefore have not had the trouble with the gas washing, but we can not use cheap fuels, as we had anticipated we could.

The large cost referred to in No. 11 (for 1906) is to-day in the same condition, but I do not believe that the high selling cost is warranted by the shop costs. 


\section{PRESENT STATUS OF THE PRODUCER-Gas POWER PLANT.}

Although the attitude of the manufacturers of producer-gas power plants was encouraging in 1906, their position to-day is extremely gratifying. Their fair-mindedness, their appreciation of the difficulties involved, and their realization of the shortcomings of the present producer-gas power plant all point directly toward the development of highly efficient gas power units which can operate on many types of fuel and can be installed at a total cost that compares favorably with that of the corresponding steam plant and at the same time insures the manufacturer a fair profit.

That there has been a definite increase in the manufacture of these plants and in the demand for them is evident from the manufacturers' statements and from the data recorded in figures 2 and 3.

Although the development of this type of power has been in a way remarkable, it must be acknowledged that difficulties have hindered the development that might be expected of a prime mover showing such marked economy in fuel consumption. These difficulties, as seen from the manufacturers' standpoint in 1906, were summed up in eleven items on pages 21-22. In order to emphasize the modifications since that date that tend to lessen these difficulties, the items will be discussed separately somewhat at length.

\section{RELIABIITY.}

1. The fact that the gas-engine plant is not so reliable as the steam-engine plant.

An examination of the replies received from the manufacturers in 1909 shows that only two out of ten regard this point as vital, and one of these feels that the difficulty is with the public rather than with the plants themselves.

Abundant testimony may be secured from owners and operators of these plants regarding reliability of such installations when properly handled. It is not proposed to reduce this discussion to a series of testimonials, but it seems consistent to report at this time the statements of the owners of a few gas-power installations.

It was the original intention to publish the letters in full over the names of the authors, but inasmuch as some of the comments might be interpreted as promoting the interests of certain manufacturers to a greater extent than others, it is deemed wise to present the substance of the communications without reference to the particular plant in question.

These statements are as follows:

(a) I have a 75-horsepower producer-gas engine and producer. I have always found it reliable and a very economical source of power. The net result of its operation, based on a ten days' test, gave me 1 horsepower for every 1.05 pounds of coal burned per hour. In average practice, however, I believe the consumption of fuel 
would be slightly higher, but I do not believe it would be in excess of 1.15 pounds per horsepower hour.

I wish to say further that I am lighting my house and stable with a 15-horsepower producer-gas plant, with an average run of 5 hours a day and an average load of fifty 16-candlepower lamps, and my total consumption of fuel for the 24 hours, including 5 hours run, will average 100 pounds. This coal costs me one-quarter of a cent a pound delivered. My lubricating oil expense is very low, as the engine is a crank-case splash, and I only have one lubricating cup on the engine to oil the journals of a small shaft.

I do not figure my time as anything, as the man who attends to this plant is regularly employed by me doing other work on my place. All the attention he has to give it is about half an hour a day, and the engine runs entirely without any supervision during the evening.

(b) In January, 1907, Company installed for us a producer-gas power plant consisting of three 50-horsepower horizontal gas engines, two of which are direct connected, making a unit of 100 horsepower, and attached direct to a generator. The other engine is a separate unit with its own generator attached. We have two gas producers, one of 100-horsepower capacity and the other of 50-horsepower capacity.

We have used this plant continuously since its installation and with satisfaction, furnishing to our plant current which is distributed throughout the works to many motors, besides furnishing light and power for one large freight and one passenger elevator.

We do not use the full capacity of the plant, holding at all times the separate unit of $\mathbf{5 0}$ horsepower in reserve.

The cost for the calendar year 1908 was as follows:

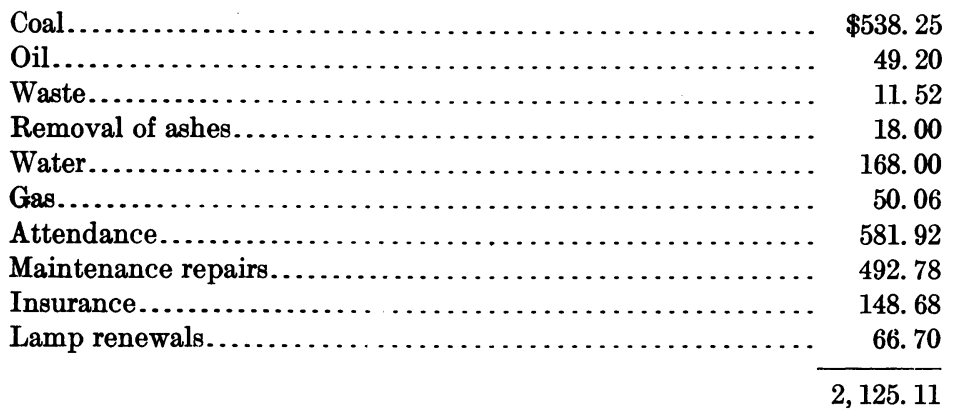

Our kilowatt hours used during the entire period amounted to 134,063 , making net cost to us of 1.585 cents per kilowatt hour.

Previous to the installation of the plant we employed a fireman to take care of the steam-heating plant, and our charge for attendance in the foregoing statement is the amount paid in excess of what we had previously paid for attendance on our steam-heating plant. We are obliged to keep steam up the year around, as we use it for several purposes in our factory, and the charge under attendance, therefore, is proper but less than would follow under other conditions.

(c) We have two gas-engine plants using producer gas. The first station has two 600-horsepower four-cycle gas engines, operated by a pair of down-draft soft-coal producers. The other plant has three 500-horsepower two-cycle double-acting engines, operated by five pressure hard-coal producers. The first plant named has given both the best economy and service, and this plant has been in every way as reliable as a first-class steam plant. The second plant named has not proved so efficient, but has been equally reliable.

(d) This plant was installed in the spring of 1906 and consists of a suction gas producer of size to furnish sufficient gas to generate 70 horsepower; a 65-horsepower 
single-cylinder heavy-duty engine; and a 13 by 12 single-acting outside-packed plunger triplex pump.

It may be well to say that the plant s giving entire satisfaction, the items of reliability and economy, both of which depend so largely upon the experience of the operator, being all that could be desired.

In an article recently published by the writer of the above, after describing numerous experiences with the plant during the early days, he goes on to say:

The results obtained from the plant are most satisfactory. Our longest continuous run to date was made from 5.15 a. m. November 24 to 1.50 a. m. December 4, 1907, $235 \frac{3}{4}$ hours. The plant has been in operation since November 2 and the stop was made for the purpose of cleaning the mixing valve and changing igniters, which occupied two hours. This was not planned in any way as a record run. Our engineer assures me that it was not absolutely necessary to stop when he did, but we had shortly before this been troubled with dirty gas, and we were curious to note what effect, if any, had been produced by increasing the amount of shavings in the cleaner. Much to our satisfaction it had proved to be of great benefit.

Our plant is now running 24 hours a day, and we are pumping $1 \frac{1}{4}$ million gallons with a coal consumption of 1,100 pounds. The record for yesterday was 62,440 revolutions; the total head, including suction lift, was 108.4 feet; coal fired, 1,085 pounds. This gives a duty of 107.6 million foot-pounds per 100 pounds of coal.

During the test of the producer-gas plant its duty per 100 pounds of coal fired exceeded 135,000,000 gallons.

I desire to call your attention to the fact that we are pumping against but 110 feet total head, while the unit is designed to work against from 160 to 170 feet total head, which it did during the test above mentioned; also to say that while the engine is now running under a little more than half load, the duty would be materially increased were it running up to rated capacity.

A letter relating to an installation of several thousand horsepower operating for several years on bituminous coal states:

(e) While during the first of our experiences with this method of power production we had some difficulties, it can be fairly said that they were chiefly due to ignorance on our part, and that under the conditions as they are to-day the plant is running as steadily and with as great a factor of reliability as we have ever experienced with steam.

(f) We installed a suction gas producer of 60 horsepower and a 25-horsepowergas engine about three and one-half years ago. During this time we have never had any trouble of any kind with said installation, nor have we spent $\$ 5$ for repairs.

We have cleaned the scrubber once since the plant was installed, and the fire in the producer has not been taken out for very nearly a year's time.

We must state that we are very much pleased with said producer and gas engine and should we find it so that we would be compelled to increase the present power system, we would certainly install just the same as we are now using.

In connection with the above beg to inform you that we average about 22 horsepower and run our engine $9 \frac{1}{2}$ hours each day, six days each week, using but 1 ton of No. 2 nut coal at the cost of $\$ 4.25$ per ton.

(g) The plant contains a 500 brake-horsepower horizontal four-cycle doubleacting engine with a 300-kilowatt direct generator and a bituminous gas-generating unit of the intermittent type. The producer plant consists of two 250-horsepower down-draft generators with auxiliaries. 
Our figures show that we can produce a brake horsepower per year with the gas plant for $\$ 30$. With the old steam plant it cost us $\$ 45$. This is for ten hours a day for approximately 300 working days a year. These figures include coal, labor, supplies, interest on investment, and depreciation of plant.

The plant has given us no more trouble than a steam plant of the same size. Our $\log$ shows that from January 1, 1907, to date (February, 1908) we have shut down only thirty-four minutes, this being due to ignition troubles once, poor gas once, and an obstructed cooling pipe once.

This plant is not offensive to the neighborhood, and noise from the exhaust is no more than from a steam engine of the same capacity. ***

No trouble is occasioned in starting, it being possible to be up to full speed in as short a time as one-half minute, the usual method of starting being to run on air for six or eight revolutions before turning on the gas.

In general, from our experience with this plant, we believe it to be both economical and dependable.

A letter received June 23, 1909, from the company owning this plant, states that since the article was written (February, 1908) from which the above abstract is taken, "The plant has given us entire satisfaction."

By reference to the observations relating to the plants which have been personally inspected (pp. 40-60) many cases of exceptional reliability and economy may be noted. Attention should be called to plant 57, in which the fire has not been drawn from the producer for over seven years.

In connection with the experimental work of the United States Geological Survey the opportunity for endurance runs has been decidedly limited, owing to the fact that the supply of any one grade of fuel has been sufficient only for a run of approximately 60 hours. The plant was operated week in and week out 120 hours a week, the engine running the full time, but the necessity of changing fuels after each 60-hour run made it imperative that two gas producers be used. In the spring of 1905 one supply of Illinois bituminous coal delivered at the St. Louis testing station was sufficient for continuous operation for several days. The test began March 8 and continued without interruption until April 1-24 consecutive days. During the entire time the engine showed no signs of heating, clogging with tar, or other trouble. It ran steadily at all times and at the end of the test was in perfect condition. The same set of igniters was used throughout the run, and gave absolutely no trouble. An inspection of the engine at the close of the test showed that the cylinders, igniters, and all working parts were in such excellent condition that the engine was not even cleaned nor its mechanism in any way changed before beginning the next test. An inspection of the producer plant at the close of the test also showed that everything was in a correspondingly good condition and the regular tests went on as usual after the close of the endurance run. 
In connection with the tests made at Norfolk the samples of coal for testing purposes were sufficiently large to warrant longer runs than the regular testing period at St. Louis.

An abstract from the log of these tests is as follows:

Test 164: 144 hours duration. Interrupted for a few minutes when an indicatorrig wire fell across an igniter circuit.

Test 165: 240 hours duration. Uninterrupted.

Test 166: $213 \frac{1}{3}$ hours duration. Shut down of $2 \frac{2}{3}$ hours because of a short circuit in igniter which was troublesome to locate.

Test 167: 44 hours duration. Uninterrupted. Reason for short test was the desire to study the effect of a shut down for a period of 36 hours, after which the test was continued as No. 168.

Test 168: 240 hours duration. Uninterrupted.

\section{LACK OF ENGINEERS.}

2. The lack of engineers who know how to run producer-gas power plants.

My comment upon this situation two years ago was:

It can not be denied that many of the difficulties charged to producer-gas power plants are due entirely to incompetent operators. Some plants have been put out of commission temporarily by the prejudices or the lack of ability and training of the operators or engineers in charge. A few of these failures are due to the impossibility of finding men competent to operate the plants, but many of them have undoubtedly been the result of a short-sighted policy on the part of some manufacturers, who are not willing to give proper and necessary information about the design, construction, and operation of the plants made by them. The possibility of a sale at the time is apparently the only interest they keep in mind, and the future is allowed to take care of itself.

Although of necessity this comment still holds to a certain extent, yet it is certainly true that conditions in these respects have greatly improved within the time indicated. There are at present many operators competent to take charge of the plants, but there are also many attempting to operate gas installations who are not in the least fitted for the work.

The attitude of the manufacturers as a whole has materially changed. The distrust and jealousies which have characterized the dealings of some in the not distant past are gradually disappearing, and on the whole to-day the manufacturers seem ready to render all the assistance possible in connection with the proper manipulation of their installations. There is, however, still room for improvement, and the indications are certainly in the right direction when the manufacturers themselves recognize these faults, as is shown by their own statements. (See items 7 and 8, p. 22.)

Many of the difficulties due to lack of knowledgè of their own plants, improper design, faulty construction, impossible contracts, and failure to render reasonable assistance in putting up and starting new installations have been due in part to undesirable competition 
and jealousy on the part of certain manufacturers. Within the past two years the varied interests working for the development of gas power have been brought more closely into touch through friendly organizations, with the result that a better understanding and a heartier cooperation is beginning to prevail. Notable among the organizations which are tending to unite these many interests on a common basis is the gas-power section of the American Society of Mechanical Engineers.

\section{INEXPERIENCED SALESMEN.}

3. Inexperienced salesmen-men not familiar with the details of the engines and producers they are handling.

A few years ago would-be purchasers had to deal with ignorant and often unscrupulous salesmen. Except possibly in a very few insignificant companies, the unscrupulous agent seems to be rapidly dropping into the background. Incompetent and uninformed salesmen will always be with us, but the situation to-day in this respect is greatly improved over that of three years ago.

\section{UNSUCCESSFUL INSTALLATIONS.}

4. The large number of unsuccessful and only partly successful installations made during the experimental period of this development.

With the reliable companies presenting their standard plants, this situation is a thing of the past. The condition still applies, however, to certain new companies in the field and also to new types of producers which are constantly appearing.

\section{DESIGN AND CONSTRUCTION.}

5. Lack of proper design and construction of producer-gas engines in the United States.

The situation to-day in this respect is the same as is encountered in the purchase of nearly all manufactured articles. There are reliable companies offering a well-tried first-class article, while others are advertising equipment which resembles the first only in external appearance and in the fact that both are labeled "gas engines" in the catalogues. Too much care can not be exercised in the selection of the proper equipment for producer-gas power plants. The assumption that one make is just as good as any other and that consequently the one to purchase is the one offered at the lowest price is leading to many regrets.

\section{PUBLIC UNCERTAINTY.}

6. Lack of knowledge and confidence on the part of the public.

Judging from the statements of the manufacturers, this still seems to be the greatest difficulty with which they have to contend. (See items $1,3,5$, and 8, p. 22.) 
Examination of figures 2 and 3 and the table on pages 65-78 will show that the public is rapidly gaining knowledge and that its confidence is being well established.

\section{SEPARATE HEATING PLANTS.}

7. The fact that the heating of factory buildings must be provided for by a heating plant separate from the power plant.

In the main this situation has not changed. Individual owners of producer-gas plants report that they are heating their buildings from these plants, but this application does not seem to be general. Until proper methods are devised for accomplishing this heating with entire satisfaction there will be many places in which, though producer-gas power plants would otherwise be desirable, it would be a mistake to make such an installation.

\section{USE WITH BITUMINOUS COAL.}

8. Lack of types of producers which will gasify bituminous coal satisfactorily.

Could the disinterested comments of a large number of producergas investigators be procured, the discussion regarding item 8 would, I believe, center about the word "satisfactorily."

The investigations by the Geological Survey have demonstrated without question that both the up-draft or pressure producer and the down-draft type will generate an excellent gas from bituminous coals, entirely suitable for the commercial operation of gas engines.

There are, of course, inherent difficulties in each type, such as the mechanical extraction of the tar in the up-draft producer, both reducing the efficiency of the plant and forcing upon the owner an undesirable by-product, and the excessive labor in cleaning the down-draft system, the requirements of cleaning also prohibiting the continuous operation of a single generator unit. Undoubtedly modifications will be made that will reduce these objections to a minimum, and other developments will gradually simplify such plants; but even as the plants exist to-day the fact is that approximately 57 per cent of the total producer-gas horsepower in this country is developed from bituminous coal and lignite.

Owing to commercial considerations these installations for the most part use fuels of good quality - that is, the regular marketable grades. That it is not necessary to restrict the operation to these better grades, so far as making gas of the proper quality is concerned, has been demonstrated beyond question by the United States Geological Survey.

The testing plant ran satisfactorily on many coals containing over 20 per cent ash. One West Virginia bone coal contained as much as 44 per cent ash, and with this fuel the consumption was only 1.65 pounds of coal as fired per brake horsepower per hour. Among the 
other fuels which may be classed as low grade and which have been successfully used in this plant are the large slaty roof slabs, or roof coal, Illinois bone, washery refuse, and Rhode Island graphitic anthracite.

Peat forms an excellent fuel, and at present two producer-gas installations for operation in this country on peat are in process of construction.

With such a wide range of available fuels, and with the supply of anthracite and the better grades of bituminous coal decidedly limited, the producer types now in use will doubtless in due time be improved and modified so as to adapt them to the lower-grade or high-ash fuels.

The general situation in Europe is not very different from our own, as owners are for the most part using the better-grade fuels and leaving the poorer grades in the mines. They recognize this as a serious situation and are deeply interested in the possible utilization of lowgrade fuels in the gas producer.

During a recent inspection trip in ten European countries I found anthracite coal, brown-coal briquets, and peat in very general use in producer-gas power plants. Bituminous coal is also extensively used, but in the majority of plants only noncaking coals, moderate in tar production and low in ash, are handled.

For one installation of many thousand horsepower the coal is taken directly from mines bought by the owners expressly for the use of their plant, but I learned that the high-grade, marketable coal is used in these producers and the grades relatively high in ash are not taken from the mine.

In two instances only was I able to learn of the use of high-ash fuels. In one installation a mixture of culm, roof coal, and washery refuse, reported as averaging 53 per cent ash, was being used in a by-product recovery plant. This plant, which was experimental, had been in commission about one year. Considerable time was required for adapting the plant for the successful handling of the fuel, but the reports indicated that for three months before my visit little or no difficulty had been experienced.

The other plant I found under full operation, using roof slabs that gave little indication, on casual inspection, of containing any combustible material. It was claimed that this fuel averaged over 60 per cent ash-a claim which seemed entirely reasonable. At the time of this visit (1908) the producers were not only supplying a number of furnaces with gas, but were also operating a 1,000-horsepower and a 250-horsepower gas engine. A 500-horsepower engine was being added to the equipment. The engines in use were direct connected to electric generators. The 10,000-volt current is used for operating the local mine machinery and also for furnishing lights for neighboring towns and power for a street railroad. The plant was reported to be using over 100 tons of this low-grade fuel per day. 
CHEAP FUELS IN SUCTION PRODUCERS.

9. Inability to use cheap fuels in the suction gas producer.

As one of the manufacturers has said (p. 22), "A satisfactory suction soft-coal producer would be a great boon to the gas engine and producer business." There are at present a few plants operating successfully on lignite, and in special cases bituminous coal has been used, but this practice can not be regarded as sufficiently satisfactory in all particulars to warrant the indiscriminate installation of such plants.

It is understood that the two producer plants now being erected in this country for operation with peat are of the suction type.

The suction plant is used in Europe for practically the same varieties of fuel as in this country, namely, anthracite coal, coke, browncoal briquets, and peat. The number of such peat producer-gas plants is great.

My attention was drawn to but one suction plant in Europe actually operating under commercial conditions upon bituminous coal. This plant appeared to give entire satisfaction, but close inquiry brought out the fact that it was necessary to secure certain grades of coal and further that it was necessary to mix three varieties in definite proportions to insure successful operation.

There is certainly opportunity for further development along this line.

\section{RELATIVE FUEL VALUES.}

10. Lack of complete knowledge as to how successfully th9 various fuels in different localities can be used in gas systems.

The special object of investigations made at the Geological Survey's fuel-testing plant for the last five years has been to determine the relative fuel value of coals found in the United States, and it is expected that, as its results become available, this work will supply the necessary information concerning the various kinds of fuel tested.

\section{EXCESSIVE COST}

11 Large excess cost of gas-engine and gas-producer power plants over that of steam-power plants.

After examination of many tables of costs, the conclusion is that complete producer-gas installations for the larger plants, say from 4,000 to 5,000 horsepower, ${ }^{a}$ cost about the same as those of firstclass steam plants of the same rating. With smaller installations the balance is probably in favor of the steam plant. However, even if the steam plant costs 15 per cent less than the producer-gas

a A 5,500-horsepower producer-gas power plant complete, including electrical machinery, bulldings, etc., all erected, is reported to have cost, including freight, $\$ 73$ per horsepower. At the same time the report was published that the corresponding figures for a competing steam plant amounted to $\$ 74$ per horsepower. 
plant, it should not be forgotten that the increased efficiency in operating the latter will make up the difference in the first cost within a short time-probably in two or three years in the average plant.

It must be acknowledged that the cost of producer-gas power installations is excessive, and that there must necessarily be a reduction in price when the amount of business will warrant it. A most encouraging sign is manifested in item 10 , page 22 , in which a manufacturer actually says, "I do not believe that the high selling cost is warranted by the shop costs."

Recently a transaction came to my attention in which a gas producer was offered at a figure which was reported to be "actual shop cost." Within ten days another company offered a plant of the same rated capacity for one-third of the price, and this manufacturer casually remarked, "and I shall not lose on it at this price." -

The demand for figures of the approximate cost of these installations has become so persistent that the following tables are presented, although somewhat incomplete.

Cost of producer-gas engines.

\begin{tabular}{|c|c|c|c|c|c|c|c|c|}
\hline \multirow[b]{2}{*}{$\begin{array}{l}\text { Horse- } \\
\text { power. }\end{array}$} & \multirow[b]{2}{*}{$\begin{array}{c}\text { Cost } \\
\text { f. o. b. } \\
\text { factory. }\end{array}$} & \multirow[b]{2}{*}{$\begin{array}{l}\text { Cost of } \\
\text { erecting. }\end{array}$} & \multirow[b]{2}{*}{$\begin{array}{l}\text { Foun- } \\
\text { dation. }\end{array}$} & \multirow[b]{2}{*}{$\begin{array}{l}\text { Cost of } \\
\text { foun- } \\
\text { dation. }\end{array}$} & \multirow{2}{*}{$\begin{array}{l}\text { Cost of } \\
\text { engine } \\
\text { erected, } \\
\text { includ- } \\
\text { ing foun- } \\
\text { dation. }\end{array}$} & \multicolumn{3}{|c|}{ Cost per horsepower. } \\
\hline & & & & & & $\begin{array}{l}\text { F. o. b } \\
\text { factory. }\end{array}$ & $\begin{array}{c}\text { Erected, } \\
\text { not in- } \\
\text { cluding } \\
\text { foun- } \\
\text { dation. }\end{array}$ & $\begin{array}{l}\text { Erected, } \\
\text { includ- } \\
\text { ing foun- } \\
\text { dation. }\end{array}$ \\
\hline 20 & $\$ 1,100$ & & Cubic feet. & $\$ 50$ & $\$ 1,150$ & $\$ 55.00$ & & \\
\hline 55 & & & & & 2,400 & & & $\$ 43.70$ \\
\hline $\begin{array}{l}60 \\
60\end{array}$ & $\begin{array}{l}2,800 \\
2,900\end{array}$ & & 350 & 105 & & $\begin{array}{l}46.70 \\
48.40\end{array}$ & & \\
\hline 75 & 3,610 & $\$ 175$ & 375 & 150 & 3,933 & 48.10 & $\$ 50.50$ & 52.40 \\
\hline 80 & 3,400 & & & & & 4250 & & \\
\hline 80 & 3,250 & & & & & 40.70 & . & $\ldots$. \\
\hline 80 & 3,830 & & & & & 47.90 & & \\
\hline $\begin{array}{l}85 \\
85\end{array}$ & $\begin{array}{l}4,150 \\
3,550\end{array}$ & & & & & $\begin{array}{l}48.90 \\
41.80\end{array}$ & & \\
\hline 100 & 4,300 & & & & & $\begin{array}{l}41.80 \\
43.00\end{array}$ & & \\
\hline 100 & 4,925 & & & & & 49.25 & $\cdots$ & \\
\hline 110 & 4. 950 & $\cdots$ & & 225 & $\cdots$ & 45.00 & $\ldots$ & \\
\hline $\begin{array}{l}110 \\
110\end{array}$ & $\begin{array}{l}4,960 \\
5,100\end{array}$ & & & * & & $\begin{array}{l}45.10 \\
46.30\end{array}$ & ...... & \\
\hline 112 & 4,200 & & & & & 37.50 & & \\
\hline 125 & 5,450 & & & & & 43. 60 & & \\
\hline 130 & 5,250 & $\cdots$ & & & & 40.40 & $\ldots$ & 的 \\
\hline $\begin{array}{l}135 \\
150\end{array}$ & $\begin{array}{l}6,600 \\
6,200\end{array}$ & & & & & $\begin{array}{l}48.90 \\
41.30\end{array}$ & & \\
\hline 160 & 5,500 & & & & & 34.40 & & \\
\hline 160 & 6,100 & 150 & 2,000 & 520 & 6,770 & 38. 10 & 39.00 & 42.30 \\
\hline $\begin{array}{l}185 \\
210\end{array}$ & $\begin{array}{l}7,800 \\
8,600\end{array}$ & $\cdots$ & $\cdots$ & & $\cdots \cdots$ & 42.20 & $\cdots$ & $\cdots \cdots$ \\
\hline 250 & 6,650 & 150 & 2,160 & 560 & 7,360 & 26.60 & 27.20 & 29.40 \\
\hline 300 & 10,500 & & & & & 35.00 & & \\
\hline 400 & 12,000 & & & & & 30.00 & & \\
\hline & 12,800 & .. & & & & 32.00 & $\ldots$ & 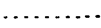 \\
\hline 600 & 17,400 & min & & & & 29.00 & 00 & 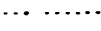 \\
\hline 2,000 & 64,850 & 875 & 5,400 & 1,400 & 67,125 & 32.43 & 32.86 & 33.56 \\
\hline
\end{tabular}


Cost per horsepower of producer-gas installations.

\begin{tabular}{|c|c|c|c|c|}
\hline $\begin{array}{l}\text { Horse- } \\
\text { power. }\end{array}$ & $\begin{array}{l}\text { Gas producer } \\
\text { and engine } \\
\text { erected, } \\
\text { exclusive of } \\
\text { foundations. }\end{array}$ & $\begin{array}{l}\text { Gas producer } \\
\text { and engine } \\
\text { erected, } \\
\text { including } \\
\text { foundations. }\end{array}$ & $\begin{array}{l}\text { Complete } \\
\text { plant, ex- } \\
\text { clusive of } \\
\text { buildings.a }\end{array}$ & $\begin{array}{c}\text { Complete } \\
\text { plant, } \\
\text { including } \\
\text { buildings, } a\end{array}$ \\
\hline $\begin{array}{r}20 \\
25 \\
25 \\
50 \\
60 \\
75 \\
75 \\
80 \\
100 \\
110 \\
110 \\
125 \\
125 \\
150 \\
200 \\
250 \\
300 \\
500 \\
1,000 \\
2,000 \\
2,800 \\
4,000 \\
4,000 \\
4,000 \\
4,800 \\
4,800 \\
5,500\end{array}$ & 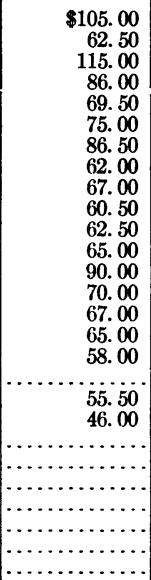 & 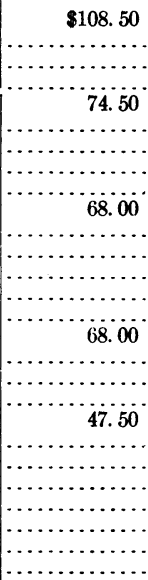 & $\begin{array}{r}\$ 100.00 \\
\cdots \\
\cdots \\
79.00 \\
84.40 \\
69.50 \\
56.50\end{array}$ & 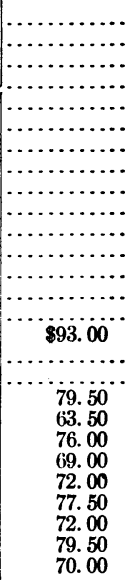 \\
\hline
\end{tabular}

$a$ Includes producer, engine, electric generator, piping, and auxiliaries, all erected, with suitable foundar tions.

Considerable variation will be noticed in the prices quoted by different manufacturers for plants of the same rated capacity. In some cases this difference is warranted by a difference in the "quality." In others it is due to a difference in the number of units installed to make up the total required horsepower or to different requirements for auxiliary equipment.

\section{OVERRATING.}

Among the difficulties in the way of the proper development of producer-gas power, special attention is called to the overrating of producers mentioned by one manufacturer (item 7, p. 22). It is exceedingly gratifying to note that this point is at last recognized by at least one of the companies building these plants. This tendency to overrate producers has been especially prevalent among the builders of the suction plants. In inspecting a large number of installations throughout the country this weakness has repeatedly attracted attention. It has been observed frequently that a given plant using anthracite fuel of good quality will present no operating difficulties when working up to 50 or 75 per cent of the rated capacity of the producer, but if the producer is forced to its full rating for any length of time, clinkering and other operating difficulties are encountered. These are often sufficiently serious to necessitate a reduction in load at a time most unfortunate for the factory. 
This overrating has come about very naturally through early attempts to adopt European figures for rate of fuel consumption. Experience with American fuels has shown that decided modifications in this fuel-consumption rate are absolutely necessary, and although some manufacturers have given this matter careful consideration it is undoubtedly true that others are still using grate areas too small for the demands which their producers are expected to meet.

In spite of the difficulties indicated, the producer-gas power plant is in the main an assured success. In fact, it is in the appreciation of these difficulties by conservative manufacturers that the possibilities of a steady and strong development lie. The true status of this type of power is well defined by a representative of one of the strongest companies in this country when he states that "the gas engine and producer have come to stay. They are of great economic value. They have their peculiar application, however, and are not a universal panacea for all our previous ills."

\section{VIEWS OF OWNERS AND OPERATORS OF PRODUCER- GAS PLANTS.}

\section{NUMBER AND CLASS OF PLANTS.}

The appended list of producer-gas power plants (pp. 65-78) indicates that at present there are over 500 such plants in operation in the United States, ranging in size from 15 to 6,000 horsepower.

Data secured from this list are summarized in the following table according to the type of fuel used, and separately for all plants above 500 horsepower and for those not exceeding 500 horsepower:

Summarized data of producer-gas power plants in United States.

\begin{tabular}{|c|c|c|c|c|c|c|c|}
\hline & \multirow{2}{*}{$\begin{array}{l}\text { No. of } \\
\text { plants. }\end{array}$} & \multicolumn{4}{|c|}{ Horsepower. } & \multirow{2}{*}{$\begin{array}{c}\text { Per cent } \\
\text { of } \\
\text { total } \\
\text { number. }\end{array}$} & \multirow{2}{*}{$\begin{array}{c}\text { Percent } \\
\text { of } \\
\text { total } \\
\text { horse- } \\
\text { power. }\end{array}$} \\
\hline & & Total. & $\begin{array}{l}\text { A ver- } \\
\text { age. }\end{array}$ & $\begin{array}{l}\text { Mini- } \\
\text { mum. }\end{array}$ & $\begin{array}{l}\text { Maxi- } \\
\text { mum. }\end{array}$ & & \\
\hline \multirow[t]{2}{*}{ 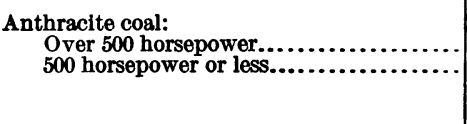 } & $\begin{array}{r}8 \\
407 \\
\end{array}$ & $\begin{array}{r}7,550 \\
40,550 \\
\end{array}$ & $\begin{array}{l}950 \\
100\end{array}$ & $\begin{array}{r}600 \\
15\end{array}$ & $\begin{array}{r}1,500 \\
500\end{array}$ & & \\
\hline & 415 & 48,100 & 116 & 15 & 1,500 & 88 & 43 \\
\hline \multirow[t]{2}{*}{ 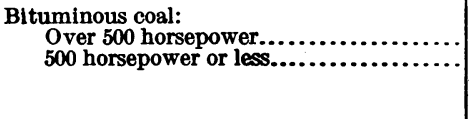 } & $\begin{array}{l}20 \\
17\end{array}$ & $\begin{array}{r}49,000 \\
5,150\end{array}$ & $\begin{array}{r}2,450 \\
300\end{array}$ & $\begin{array}{r}750 \\
35\end{array}$ & $\begin{array}{r}6,000 \\
500\end{array}$ & & \\
\hline & 37 & 54,150 & 1,460 & 35 & 6,000 & 8 & 49 \\
\hline \multirow[t]{2}{*}{$\begin{array}{l}\text { Lignite: } \\
\quad \text { Over } 500 \text { horsepower..................... } \\
\quad 500 \text { horsepower or less................ }\end{array}$} & $\begin{array}{r}3 \\
19 \\
\end{array}$ & $\begin{array}{l}7,275 \\
1,725 \\
\end{array}$ & $\begin{array}{r}2,430 \\
90 \\
\end{array}$ & $\begin{array}{r}525 \\
25 \\
\end{array}$ & $\begin{array}{r}3,750 \\
250 \\
\end{array}$ & & \\
\hline & 22 & 9,000 & 410 & 25 & 3,750 & 4 & 8 \\
\hline 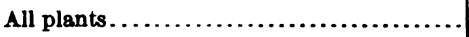 & 474 & 111,250 & 235 & 15 & 6,000 & 100 & 100 \\
\hline
\end{tabular}


It will be observed from this table that about 88 per cent of the total number of installations in this country are operating on anthracite coal (a few using charcoal or coke), and that bituminous coal and lignite are used in the remaining 12 per cent. Of the total horsepower approximately 57 per cent is derived from bituminous coal and lignite and 43 per cent from anthracite coal, charcoal, and coke. In point of size it will be noted that the bituminous plants average $12 \frac{1}{2}$ times the size of the anthracite plants.

\section{NOTES OF INSPECTION.}

With the above information at hand it is interesting to examine several of the plants from the standpoint of the owners and operators. This information was secured through my personal inspection during the summer of 1906, and by Mr. C. D. Smith, assistant engineer, United States Geological Survey, in 1908.

No plan was followed in selecting the plants to be visited, and, with one or two exceptions, no notice of the inspection was given the owners or operators before arrival at the plant.

In the following table are presented the essential details of the plants'visited. The observations which follow the table were made and recorded at the time of the visits:

Summarized particulars of producer-gas power installations visited.

\begin{tabular}{|c|c|c|c|c|c|c|c|c|c|}
\hline \multirow[b]{2}{*}{ 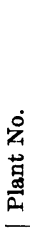 } & \multicolumn{4}{|c|}{ Producers. } & \multicolumn{3}{|c|}{ Fuel. } & \multirow[b]{2}{*}{ Water supply. } & \multirow[b]{2}{*}{$\begin{array}{l}\text { Number of } \\
\text { men required } \\
\text { each shift. }\end{array}$} \\
\hline & Type. & 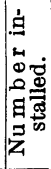 & 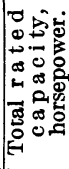 & 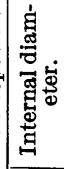 & $\begin{array}{l}\text { Kind and } \\
\text { size. }\end{array}$ & $\begin{array}{c}\text { Amount } \\
\text { used (ap- } \\
\text { proximate). }\end{array}$ & $\begin{array}{l}\text { Method of } \\
\text { charging. }\end{array}$ & & \\
\hline 1 & Suction.. & 1 & 25 & In. & Anth. pea. & $\begin{array}{l}\text { Pounds. } \\
1.25 \text { p e r } \\
\text { b.h.p.hr. }\end{array}$ & & & \\
\hline $\begin{array}{l}2 \\
3\end{array}$ & $\begin{array}{l}\ldots \text { do........ } \\
\ldots \text { do } \ldots\end{array}$ & $\begin{array}{l}1 \\
1\end{array}$ & $\begin{array}{l}25 \\
30\end{array}$ & & $\dddot{A}_{\mathrm{n}} \mathrm{d}, \mathrm{h}$ & 300 per day. & $\begin{array}{l}3 \text { timesa day } \\
\text { Once an }\end{array}$ & City mains. & $\begin{array}{l}\text { One. } \\
5 \text { hrs. time of }\end{array}$ \\
\hline 4 & ...do. & 1 & 30 & & $\begin{array}{l}\text { buck. } \\
\text { Anth. pea. }\end{array}$ & & hour. & & $\begin{array}{l}\text { one. } \\
\text { Part time of } \\
\text { one. }\end{array}$ \\
\hline 5 & ...do.. & 1 & 35 & & $\begin{array}{l}\text { Anth.and } \\
\text { se mi - } \\
\text { anth., } \\
\text { mixed. }\end{array}$ & $\begin{array}{l}1.6 \text { per b.h.p. } \\
\text { hr. }\end{array}$ & & City mains.... & $\begin{array}{c}\text { One } \\
\text { shifts). }\end{array}$ \\
\hline 6 & ... do..... & 1 & 50 & $\cdots$ & Anth. pea. & 400 per day.. & $\begin{array}{l}\text { Varies with } \\
\text { load. }\end{array}$ & Well........... & $\begin{array}{l}\text { One } 2 \text { hrs. per } \\
\text { day. }\end{array}$ \\
\hline $\begin{array}{l}7 \\
8\end{array}$ & $\begin{array}{l}\ldots \text { do....... } \\
\ldots \text {. do...... }\end{array}$ & $\begin{array}{l}1 \\
1\end{array}$ & $\begin{array}{l}50 \\
50\end{array}$ & $\begin{array}{c}28 \\
\ldots\end{array}$ & $\mid \begin{array}{l}\ldots \text { do } \ldots . . . . \\
\ldots \text { do....... }\end{array}$ & 450-500 p.d.. & Twice a day. & Pressure main. & 万 \\
\hline $\begin{array}{r}9 \\
10\end{array}$ & $\begin{array}{l}\ldots \text { do............. } \\
\ldots . \text { do.... }\end{array}$ & $\begin{array}{l}1 \\
1\end{array}$ & $\begin{array}{l}50 \\
50\end{array}$ & & $\ldots$ do & 240 per day.. & 3 times a day & 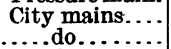 & Do. \\
\hline 11 & $\begin{array}{l}\ldots \text { do...... } \\
\ldots \text { do..... }\end{array}$ & $\begin{array}{l}1 \\
1\end{array}$ & $\begin{array}{l}50 \\
50\end{array}$ & 36 & $\begin{array}{l}\text { Anth. pea. } \\
\text {..do........ }\end{array}$ & $\begin{array}{l}300-100 \text { p. d.. } \\
700 \text { per day.. }\end{array}$ & 3 times a day & weill................ & $\begin{array}{l}\text { Do. } \\
\text { One. }\end{array}$ \\
\hline 13 & ... do... & 1 & 50 & 28 & ...do & 1,34 & $\begin{array}{c}\mathrm{E} \text { ver y } 30 \\
\text { mins. }\end{array}$ & Pressure main. & $\begin{array}{l}\text { Part time of } \\
\text { two. }\end{array}$ \\
\hline 14 & ...do..... & 1 & 50 & 36 & ...do....... & $\begin{array}{l}450-500 \text { per } \\
\text { day. }\end{array}$ & $\begin{array}{l}\text { Fill every } \\
\text { m o rning, } \\
\text { charge as } \\
\text { needed. }\end{array}$ & City mains.... & $\begin{array}{l}\text { One } 2 \text { hrs. per } \\
\text { day. }\end{array}$ \\
\hline $\begin{array}{l}15 \\
16\end{array}$ & $\begin{array}{l}\ldots \text { do..... } \\
\ldots . \text { do..... }\end{array}$ & $\begin{array}{l}1 \\
1\end{array}$ & $\begin{array}{l}50 \\
50\end{array}$ & 30 & $\begin{array}{l}\ldots \text { do } \ldots . . . . \\
\ldots \text { do....... }\end{array}$ & $\begin{array}{l}300) \text { per day.. } \\
550 \text { per day.. }\end{array}$ & $\begin{array}{l}\text { Twice a day. } \\
\text { Every } 25 \text { to }\end{array}$ & $\begin{array}{l}\text { Well........... } \\
\text { City water... }\end{array}$ & $\begin{array}{l}\text { Do. } \\
\text { Do. }\end{array}$ \\
\hline 17 & ..do..... & 1 & 50 & 28 & ...do. & 650 per day.. & 4 times a day & Well. & $\begin{array}{l}\text { Half time of } \\
\text { one. }\end{array}$ \\
\hline
\end{tabular}


Summarized sarticulars of producer-gas power installations visited-Continued.

\begin{tabular}{|c|c|c|c|c|c|c|c|c|c|}
\hline \multirow[b]{2}{*}{ 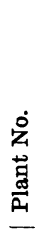 } & \multicolumn{4}{|c|}{ Producers. } & \multicolumn{3}{|c|}{ Fuel. } & \multirow[b]{2}{*}{ Water supply. } & \multirow[b]{2}{*}{$\begin{array}{l}\text { Number of } \\
\text { men required } \\
\text { each shift. }\end{array}$} \\
\hline & Type. & 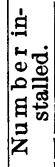 & 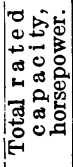 & 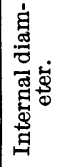 & $\begin{array}{l}\text { Kind and } \\
\text { size. }\end{array}$ & $\begin{array}{c}\text { Amount } \\
\text { used (ap- } \\
\text { proximate). }\end{array}$ & $\begin{array}{l}\text { Method of } \\
\text { charging. }\end{array}$ & & \\
\hline 18 & Suction & 1 & 60 & In. & Charcoal. & $\begin{array}{l}\text { Pounds. } \\
1 \text { per b. h. p. }\end{array}$ & & City main.. & One. \\
\hline 19 & ...do.. & 1 & 6.0 & 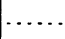 & Anth. pea. & 335 per day.. & Twice a day. & & $2 \mathrm{hrs}$. time of \\
\hline 20 & ...do.. & 1 & 60 & & A n t h & $1-1.5$ p e r & 3 times a day & & $\begin{array}{l}\text { Part time of } \\
\text { two. }\end{array}$ \\
\hline $\begin{array}{l}21 \\
22\end{array}$ & ...do. & 1 & 60 & & Anth. pea. & & & Pressure main. & \\
\hline $\begin{array}{l}22 \\
23\end{array}$ & $\begin{array}{l}\text {...do... } \\
\text {..d do.. }\end{array}$ & $\begin{array}{l}1 \\
1\end{array}$ & $\begin{array}{l}70 \\
75\end{array}$ & & ‥do....... & $\begin{array}{r}300 \text { in } 7 \mathrm{hrs} . \\
\ldots \ldots \ldots \ldots \ldots\end{array}$ & & 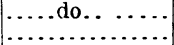 & One. \\
\hline 24 & ...do... & 1 & 75 & & Anth. pea. & & & & $\begin{array}{l}\text { Part time of } \\
\text { one. }\end{array}$ \\
\hline $\begin{array}{l}25 \\
26\end{array}$ & $\begin{array}{l}\ldots \text { do... } \\
\ldots \text { do.. }\end{array}$ & $\begin{array}{l}1 \\
1\end{array}$ & $\begin{array}{l}80 \\
95\end{array}$ & & $\begin{array}{l}\text {..do. } \\
\ldots \text {.do. }\end{array}$ & $1,000$. & f: times a day & Well.. & Two. \\
\hline 27 & ..do. & $\hat{1}$ & 100 & & ... do. & $\ldots \ldots \ldots$ & ............... & City mains.... & One. \\
\hline $\begin{array}{l}28 \\
29\end{array}$ & $\begin{array}{l}\text {..do. } \\
\text {...do. }\end{array}$ & $\begin{array}{l}1 \\
1\end{array}$ & $\begin{array}{l}100 \\
100\end{array}$ & & ...do & & $\mid \ldots \ldots \ldots \ldots$ & ...do........... & \\
\hline 30 & $\therefore$ do. & 1 & 100 & 36 & ...do. & 700 per day & A bout once & Well. & Do. \\
\hline 31 & ...do. & 1 & 100 & & ...do. & $\begin{array}{c}1,000-1,200 \\
\text { per day. }\end{array}$ & $\begin{array}{l}3 \text { or } 4 \text { times } \\
\text { a day. }\end{array}$ & $\begin{array}{l}\text { City water } \\
\text { with cooling } \\
\text { tower. }\end{array}$ & Do. \\
\hline 32 & ...do. & 1 & 120 & & ...do........ & $1,000-1,200$ & .....do....... & City mains.... & Do. \\
\hline 33 & ...do. & 1 & 120 & & ...do.. & $800-900$ per & Twice a day. & Wells. & $\begin{array}{l}\text { One } 4 \text { hrs. per } \\
\text { day. }\end{array}$ \\
\hline 34 & ...do. & 1 & 125 & & ...do... & $\begin{array}{l}\text { Less than } 1 \\
\text { per b.h.p. } \\
\text { hr. }\end{array}$ & $\begin{array}{l}5 \text { times in } 24 \\
\text { hrs. }\end{array}$ & $\cdots$ & One. \\
\hline $\begin{array}{l}35 \\
36\end{array}$ & $\begin{array}{l}\ldots \text {.do......... } \\
\ldots \text {..do..... }\end{array}$ & $\begin{array}{l}1 \\
1\end{array}$ & $\begin{array}{l}125 \\
125\end{array}$ & & $\begin{array}{l}\ldots \text { do... } \\
\ldots \text {. do... }\end{array}$ & 850 per day. & 3 or 4 times & City mains... & Do. \\
\hline $\begin{array}{l}37 \\
38\end{array}$ & $\begin{array}{l}\text {..do. } . \\
\ldots \text { do.. }\end{array}$ & $\begin{array}{l}1 \\
2\end{array}$ & $\begin{array}{l}130 \\
(a)\end{array}$ & & $\begin{array}{l}\text {...do. } \\
\text {...do. }\end{array}$ & 875 per day. & $\begin{array}{l}\text { a day. } \\
4 \text { times a day }\end{array}$ & River. & Do. \\
\hline 39 & ...do. & $\tilde{1}$ & 150 & & ...do. & $\begin{array}{l}1.8 \text { per b.h.p. } \\
\text { hr. inc. }\end{array}$ & $\begin{array}{l}70 \text { lbs. each } \\
\text { hour. }\end{array}$ & & Do. \\
\hline 40 & ...do.. & 1 & 150 & 54 & ...do. & $\begin{array}{l}500 \cdot 600 \text { per } \\
\text { day. }\end{array}$ & $\begin{array}{l}\text { Every } 2 \text { to } \\
213 \text { hours. }\end{array}$ & Well.. & Do. \\
\hline 41 & ...do. & 1 & 200 & & $A \mathrm{nth}$. & 136 per hr... & & & \\
\hline 42 & ...do.. & 1 & 200 & 84 & Anth. pea. & 1,000 per day & $\begin{array}{l}125 \text { lbs. at a } \\
\text { ch a r g e } \\
\text { w h e n } \\
\text { needed. } \\
\text { Every hour }\end{array}$ & Pressure main. & Two. \\
\hline 44 & ...do. & 1 & 200 & 60 & ...do & 900 per day. & $\begin{array}{l}\text { and a hall. } \\
3 \text { times a day }\end{array}$ & City mains... & One. \\
\hline 45 & $\ldots$ do & 1 & 200 & & ... do. & $\begin{array}{l}2 \text { per b. h. p. } \\
\text { hr. }\end{array}$ & $\begin{array}{l}1,000 \text { ll s } \\
\text { ch a d ged } \\
\text { each morn- }\end{array}$ & & $\begin{array}{l}\text { Part time of } \\
\text { one.b }\end{array}$ \\
\hline 46 & ...do. & 1 & 300 & & $\ldots$ do..... & 2,200 per day & A c c o rding & River.... & $\begin{array}{l}\text { Part time of } \\
\text { three. }\end{array}$ \\
\hline 47 & ...do. & 2 & 300 & 42 & ...do....... & 1,800 per day & $\underset{\text { mins. }}{\text { Every }} 40$ & City water... & Two. \\
\hline 48 & ...do. & 2 & 350 & $\begin{array}{l}54 \\
66\end{array}$ & $\left\{\begin{array}{c}\text { Anth. } \\
\text { buck. } \\
\text { No. } 1 .\end{array}\right.$ & 3,800 per day & Every 6 hrs. & Well. & Do. \\
\hline 49 & Pressure. & 1 & 85 & & Anth. pea. & $\begin{array}{l}800-1.000 \text { per } \\
\text { day. }\end{array}$ & $\begin{array}{l}175 \text { lbs. at a } \\
\text { c h a g e } \\
\text { w h e n } \\
\text { needed. }\end{array}$ & City mains. & Do. \\
\hline $\begin{array}{l}50 \\
51\end{array}$ & $\begin{array}{l}\ldots \text { do } \ldots . . . \\
\ldots \text { do..... }\end{array}$ & $\begin{array}{l}1 \\
1\end{array}$ & $\begin{array}{l}200 \\
200\end{array}$ & & $\begin{array}{l}\text { Anth. egg. } \\
\text { Anth. pea. }\end{array}$ & $\begin{array}{l}1,600 \text { per day } \\
2,700-3,200\end{array}$ & $\begin{array}{l}4 \text { times a day } \\
\text { Every hour. }\end{array}$ & 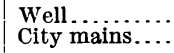 & $\begin{array}{l}\text { Do. } \\
\text { Do. }\end{array}$ \\
\hline 52 & & 1 & 250 & 84 & ...do....... & $\begin{array}{l}\text { per day. } \\
1,700-1,800 \\
\text { per day. }\end{array}$ & $\begin{array}{l}150 \text { lbs.about } \\
\text { once a n } \\
\text { hour. }\end{array}$ & .....do. & $\begin{array}{l}\text { P: rt time of } \\
\text { two. }\end{array}$ \\
\hline 53 & ...do. & 1 & 250 & & Bit & & & & $\begin{array}{l}\text { Full time of } \\
\text { one and part } \\
\text { time of one. }\end{array}$ \\
\hline
\end{tabular}


Summarized particulars of producer-gas power installations visited-Continued.

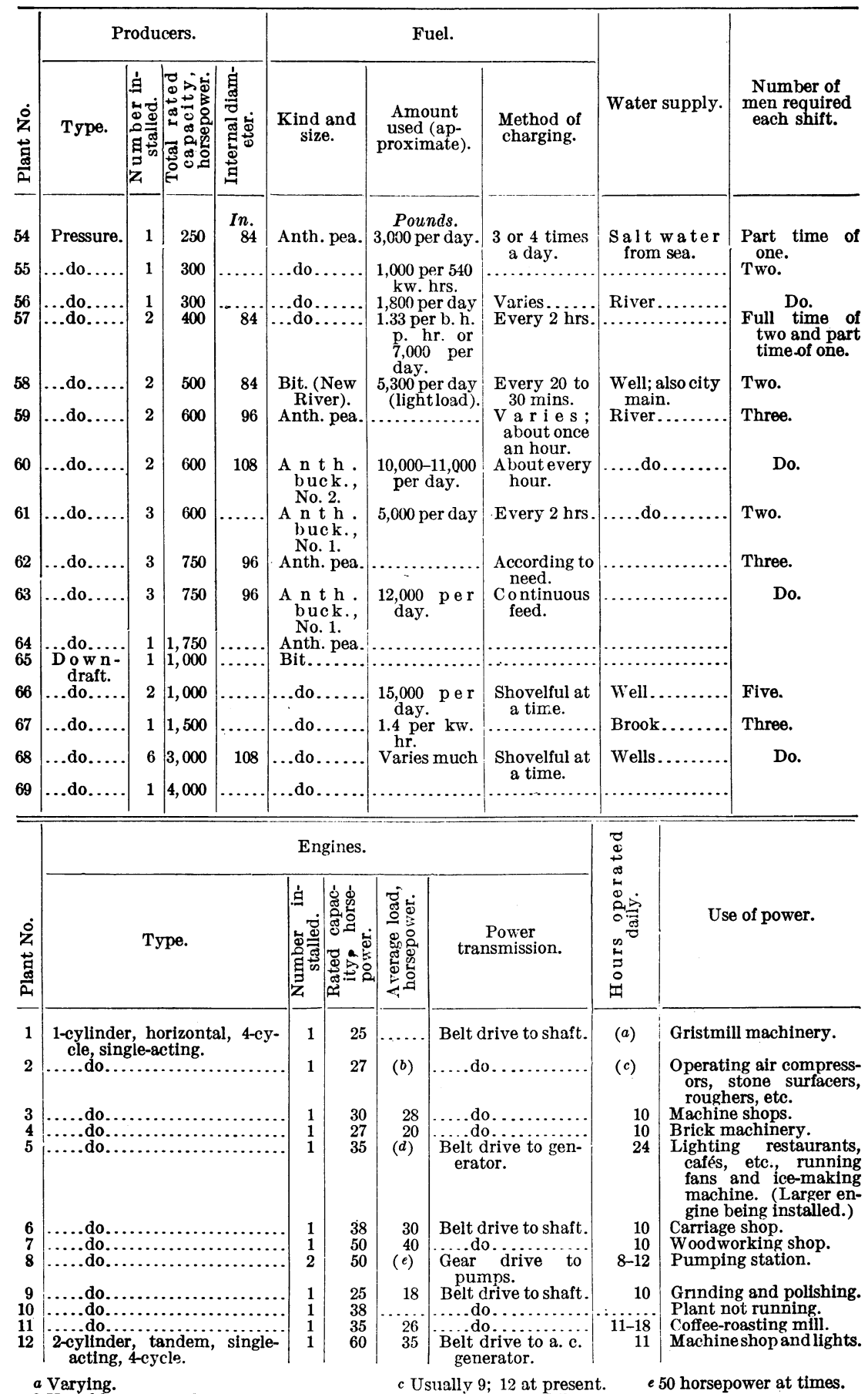

$a$ Varying.

c Usually 9; 12 at present. $d$ Variable; 1 to 24 kilowatts. 
Summarized particulars of producer-gas power installations visited-Continued.

\begin{tabular}{|c|c|c|c|c|c|c|c|}
\hline \multirow[b]{2}{*}{ 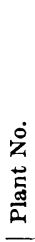 } & \multicolumn{5}{|c|}{ Engines. } & \multirow{2}{*}{ 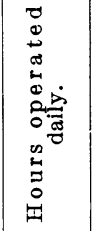 } & \multirow[b]{2}{*}{ Use of power. } \\
\hline & Type. & 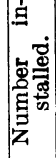 & 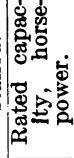 & 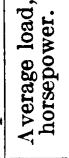 & $\begin{array}{c}\text { Power } \\
\text { transmission. }\end{array}$ & & \\
\hline 13 & $\begin{array}{l}\text { 2-cylinder, vertical, single- } \\
\text { acting, 4-cycle. }\end{array}$ & 1 & 35 & 35 & $\begin{array}{l}\text { Belt drive to cen- } \\
\text { trifugal pump. }\end{array}$ & 24 & Pumping station. \\
\hline 14 & $\begin{array}{l}\text { 3-cylinder, vertical, single- } \\
\text { acting, 4-cycle. }\end{array}$ & 1 & 60 & 35 & Belt drive to shaft. & 12 & $\begin{array}{l}\text { Chocolate grinding and } \\
\text { ice machine. }\end{array}$ \\
\hline 15 & $\begin{array}{l}\text { 1-cylinder, horizontal, single- } \\
\text { acting, 4-cycle. }\end{array}$ & 1 & 20 & 10 & ....do & 10 & Concrete mixer. \\
\hline 16 & $\begin{array}{l}\text { 3-cylinder, vertical, single- } \\
\text { acting, 4-cycle. }\end{array}$ & 1 & 45 & & .....do. & $10^{\circ}$ & Wire-drawing machines. \\
\hline 17 & $\begin{array}{l}\text { 1-cylinder, horizontal, single- } \\
\text { acting, 4-cycle }\end{array}$ & 1 & 38 & & ....do. & 10 & Factory. \\
\hline 18 & $\begin{array}{l}\text { 2-cylinder, vertical, single- } \\
\text { acting, 4-cycle. }\end{array}$ & 1 & a 68 & & ....do & 10 & $\begin{array}{l}\text { Shoe machinery and a } \\
\text { 100-light dynamo. }\end{array}$ \\
\hline 19 & $\begin{array}{l}\text { 1-cylinder, horizontal, 4-cy- } \\
\text { cle, single-acting. }\end{array}$ & 1 & 25 & 20 & .....do. & 10 & Shop machinery. \\
\hline 20 & $\begin{array}{l}\text { 2-cylinder, vertical, single- } \\
\text { acting, 4-cycle. }\end{array}$ & 1 & 50 & 30 & ....do. & 10 & $\begin{array}{l}225 \text { sewing machines and } \\
\text { a } 12 \frac{1}{2}-\mathrm{kw} \text {. dynamo for } \\
\text { lights. }\end{array}$ \\
\hline 21 & 1-cylinder, horizontal, 4-cycle. & 1 & 80 & (b) & Belt drive. & & Town pumping and \\
\hline 22 & $\begin{array}{l}\text { 1-cylinder, horizontal, 4-cy- } \\
\text { cle, single-acting. }\end{array}$ & 1 & 65 & 20 & $\begin{array}{l}\text { Gear drive to } \\
\text { pumps. }\end{array}$ & (c) & Pumping station. \\
\hline 23 & $\begin{array}{l}\text { 3-cylinder, vertical, single- } \\
\text { acting, 4-cycle. }\end{array}$ & 1 & 75 & & Belt drive to shaft. & & $\begin{array}{l}\text { Machinery for grinding, } \\
\text { polishing, etc. }\end{array}$ \\
\hline 24 & $\begin{array}{l}\text { 1-cylinder, horizontal, 4-cy- } \\
\text { cle, single-acting. }\end{array}$ & 1 & 60 & & & 20 & Shops. \\
\hline 25 & $\begin{array}{l}\text { 3-cylinder, vertical, single- } \\
\text { acting, 4-cycle. }\end{array}$ & 1 & 70 & (d) & & & $\begin{array}{l}\text { Street and house light- } \\
\text { ing. }\end{array}$ \\
\hline 26 & $\begin{array}{l}\text { 1-cylinder, horizontal, single- } \\
\text { acting, 4-cycle. }\end{array}$ & 2 & 80 & & Belt drive to shaft. & 9 & Foundry and shops. \\
\hline 27 & $\begin{array}{l}\text { 3-cylinder, vertical, single- } \\
\text { acting, 4-cycle. }\end{array}$ & 1 & 55 & & $\begin{array}{l}\text { Belt drive to } 37.5- \\
\mathrm{kw} \text {. generator. }\end{array}$ & 24 & $\begin{array}{l}\text { Operating printing } \\
\text { presses and lighting } \\
\text { the block. }\end{array}$ \\
\hline 28 & $\begin{array}{l}\text { One 3-cylinder, vertical, sin- } \\
\text { gle-acting, 4-cycle, and one } \\
\text { 1-cylinder, horizontal, 4- } \\
\text { cycle, single-acting. }\end{array}$ & 2 & 100 & & Belt drive to shaft. & & Machine shop. \\
\hline 29 & & & & & & & $\begin{array}{l}\text { Used only for testing gas } \\
\text { engines. }\end{array}$ \\
\hline 30 & $\begin{array}{l}\text { 2-cylinder, vertical, single- } \\
\text { acting, 4-cycle. }\end{array}$ & 1 & 100 & & Belt drive to shaft. & $9 \frac{1}{2}$ & Grinding and polishing. \\
\hline 31 & $\begin{array}{l}\text { 3-cylinder, vertical, single- } \\
\text { acting, 4-cycle. }\end{array}$ & 1 & 100 & 60 & $\begin{array}{l}\text { Belt drive to gen- } \\
\text { erator. }\end{array}$ & $10 \frac{1}{2}$ & Machine shop and light. \\
\hline 32 & $\begin{array}{l}\text { 1-cylinder, horizontal, single- } \\
\text { acting, 4-cycle. }\end{array}$ & 2 & 110 & & Belt drive to shaft. & 9 & $\begin{array}{l}\text { Light and power for fac- } \\
\text { tory. }\end{array}$ \\
\hline $\begin{array}{l}33 \\
34\end{array}$ & $\begin{array}{l}\text { 3-cylinder, vertical, single- } \\
\text { acting, 4-cycle. }\end{array}$ & $\begin{array}{l}2 \\
1\end{array}$ & $\begin{array}{l}88 \\
75\end{array}$ & $\begin{array}{l}60 \\
90\end{array}$ & Belt drive to shaft. & $\begin{array}{l}11 \\
22 \frac{1}{2}\end{array}$ & $\begin{array}{l}\text { Gristmill and elevators. } \\
\text { Shops. }\end{array}$ \\
\hline 35 & $\begin{array}{l}\text { 2-cylinder, vertical, single- } \\
\text { acting, 4-cycle. }\end{array}$ & 1 & 125 & & & 11 & $\begin{array}{l}\text { Grain-elevator machin- } \\
\text { ery. }\end{array}$ \\
\hline 36 & $\begin{array}{l}\text { 1-cylinder, horizontal, single- } \\
\text { acting, 4-cycle. }\end{array}$ & 1 & 60 & 40 & $\begin{array}{l}\text { Belt drive to gen- } \\
\text { erator. }\end{array}$ & 10 & $\begin{array}{l}\text { Light and power for } \\
\text { shops; gas used for } \\
\text { heating also. }\end{array}$ \\
\hline 37 & $\cdots$ & 2 & 120 & 60 & $\ldots d$ & 11 & Shops and factory. \\
\hline 38 & $\begin{array}{l}2 \text {-cylinder, vertical, single- } \\
\text { acting, 4-cycle. }\end{array}$ & 1 & 150 & & & & Factory purposes. \\
\hline 39 & 3-cylinder, vertical, 4-cycle. & 2 & 125 & 65 & $\begin{array}{l}\text { Direct connected } \\
\text { to generators. }\end{array}$ & 11 & $\begin{array}{l}\text { Electric power for fac- } \\
\text { tory and lighting. }\end{array}$ \\
\hline 40 & $\begin{array}{l}\text { 3-cylinder, vertical, single- } \\
\text { acting, 4-cycle. }\end{array}$ & 1 & 89 & 45 & & 10 & $\begin{array}{l}\text { Light and small ma- } \\
\text { chines. }\end{array}$ \\
\hline 41 & $\begin{array}{l}\text { 1-cylinder, horizontal, t-cy- } \\
\text { cle, single-acting. }\end{array}$ & 2 & 200 & & $\begin{array}{l}\text { Belt drive to gen- } \\
\text { erator. }\end{array}$ & 11 & Factory purposes. \\
\hline 42 & $\begin{array}{l}\text { One } 3 \text {-cylinder and one } 2- \\
\text { cylinder vertical, single- } \\
\text { acting, 4-cycle. }\end{array}$ & 2 & 210 & 70 & $\begin{array}{l}\text { One belt drive; } \\
\text { the other direct } \\
\text { connected to } \\
\text { generator. }\end{array}$ & 10 & Shops. \\
\hline 43 & $\begin{array}{l}\text { 3-cylinder, vertical, single- } \\
\text { acting, 4-cycle. }\end{array}$ & 2 & 152 & 50 & $\begin{array}{l}\text { Gear d rive to } \\
\text { pumps. }\end{array}$ & $9-10$ & $\begin{array}{l}\text { Pumping station. (Du- } \\
\text { plicate plant.) }\end{array}$ \\
\hline 44 & & 2 & 200 & 90 & $\begin{array}{l}\text { Direct connected } \\
\text { to generator. }\end{array}$ & 11 & 10 \\
\hline 45 & $\ldots \mathrm{d}$ & 1 & 100 & & $\begin{array}{l}\text { Belt drive to gen- } \\
\text { erator. }\end{array}$ & .. & Factory purposes. \\
\hline & ep & & & & & & \\
\hline
\end{tabular}


Summarized particulars of producer-gas power installations visited-Continued.

\begin{tabular}{|c|c|c|c|c|c|c|c|}
\hline \multirow[b]{2}{*}{ 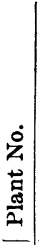 } & \multicolumn{5}{|c|}{ Engines. } & \multirow{2}{*}{ 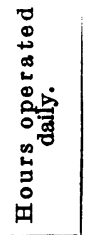 } & \multirow[b]{2}{*}{ Use of power. } \\
\hline & Type. & 吾 & 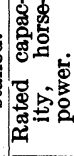 & 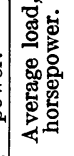 & $\begin{array}{c}\text { Power } \\
\text { transmission. }\end{array}$ & & \\
\hline 46 & $\begin{array}{l}\text { 2-cylinder, tandem, single- } \\
\text { acting, 4-cycle. }\end{array}$ & 1 & 200 & 160 & Belt drive to gen- & 11 & Grinding and general \\
\hline 47 & $\begin{array}{l}\text { 3-cylinder, vertical, single- } \\
\text { acting, 4-cycle. }\end{array}$ & 3 & 300 & 100 & $\begin{array}{l}\text { Direct connected } \\
\text { to generator. }\end{array}$ & 14 & $\begin{array}{l}\text { purposes. } \\
\text { Charging station garage. }\end{array}$ \\
\hline 49 & 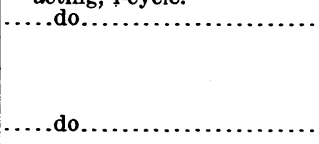 & 4 & 400 & 160 & $\begin{array}{l}\text { Two direct con- } \\
\text { nected to gener- } \\
\text { ators; two metal- } \\
\text { link belt drive } \\
\text { to compressors. } \\
\text { Belt drive to shaft. }\end{array}$ & 24 & $\begin{array}{l}\text { Refrigeration, light, and } \\
\text { power. (Duplicate } \\
\text { plant.) } \\
\text { Light and power for fac- }\end{array}$ \\
\hline 50 & $\begin{array}{l}\text { 1-cylinder, horizontal, single- } \\
\text { acting, 4-cycle. }\end{array}$ & 2 & 175 & 130 & $\begin{array}{l}\text { One, direct con- } \\
\text { nected to gener- } \\
\text { ator; other, belt } \\
\text { drive to genera- } \\
\text { tor. }\end{array}$ & 10 & $\begin{array}{l}\text { tory. } \\
\text { Shops. }\end{array}$ \\
\hline 51 & $\begin{array}{l}\text { 3-cylinder, vertical, single- } \\
\text { acting, 4-cycle. }\end{array}$ & 2 & 180 & 160 & $\begin{array}{l}\text { Direct connected } \\
\text { to generator. }\end{array}$ & 24 & $\begin{array}{l}\text { Generating current for } \\
\text { electrolysis. }\end{array}$ \\
\hline 52 & $\begin{array}{l}\text { 3-cylinder, vertical, single- } \\
\text { acting, 4-cycle. }\end{array}$ & (a) & (b) & 60 & ....do.............. & 11 & $\begin{array}{l}\text { Light and power in } \\
\text { cleaning and dyeing } \\
\text { plant. Gas also used } \\
\text { for heating flatirons. }\end{array}$ \\
\hline 53 & $\begin{array}{l}\text { Horizontal, tandem, double- } \\
\text { acting, 4-cycle. }\end{array}$ & 1 & 250 & 250 & ....do... & 11 & \\
\hline 54 & $\begin{array}{l}\text { 1-cylinder, horizontal, single- } \\
\text { acting, 4-cycle. }\end{array}$ & 2 & 250 & & $\begin{array}{l}\text { One, direct con- } \\
\text { nected to gener- } \\
\text { ator; other, belt } \\
\text { drive to shaft. }\end{array}$ & 10 & $\begin{array}{l}\text { Machine shop, cranes, } \\
\text { and light. }\end{array}$ \\
\hline 55 & $\begin{array}{l}\text { 3-cylinder, vertical, single- } \\
\text { acting, 4-cycle. }\end{array}$ & 3 & 415 & (c) & $\begin{array}{l}\text { Direct connected } \\
\text { to a. c. gener- } \\
\text { ators. }\end{array}$ & $d 24$ & $\begin{array}{l}\text { Town lighting, both for } \\
\text { streets and dwellings. }\end{array}$ \\
\hline 56 & $\begin{array}{l}\text { 3-cylinder, vertical, single- } \\
\text { acting, 4-cycle. }\end{array}$ & 1 & 270 & 150 & $\begin{array}{l}\text { Direct. connected } \\
\text { to generator. }\end{array}$ & 11 & $\begin{array}{l}\text { Machine shop and foun- } \\
\text { dry. }\end{array}$ \\
\hline 57 & $\begin{array}{l}\text { One 2-cylinder, vertical, sin- } \\
\text { gle-acting; two horizontal, } \\
\text { 2-cylinder, single-acting; } \\
\text { five (in 1906-three in 1908) } \\
\text { horizontal, 1-cylinder, sin- } \\
\text { gle-acting, 4-cycle. }\end{array}$ & (e) & $(f)$ & $(g)$ & $\begin{array}{l}3 \text { belted to genera- } \\
\text { tors; } 3 \text { belted to } \\
\text { compressors; } 2 \\
\text { belted to con- } \\
\text { veyor shafting. }\end{array}$ & (h) & $\begin{array}{l}\text { Air and gas compress- } \\
\text { ing, ash and coal con- } \\
\text { veyors, electric light- } \\
\text { ing. }\end{array}$ \\
\hline 58 & $\begin{array}{l}\text { 2-cylinder, tandem, double- } \\
\text { acting, 4-cycle. }\end{array}$ & 1 & 500 & $4 \div 5$ & $\begin{array}{l}\text { Direct connected } \\
\text { to generator. }\end{array}$ & 12 & Machineshop and lights. \\
\hline 59 & $\begin{array}{l}\text { 3-cylinder, vertical, single- } \\
\text { acting, 4-cycle. }\end{array}$ & 3 & 900 & 450 & do & 24 & $\begin{array}{l}\text { Shops and electric } \\
\text { cranes. }\end{array}$ \\
\hline 60 & $\begin{array}{l}\text { 2-cylinder, tandem, double- } \\
\text { acting, 4-cycle. }\end{array}$ & 1 & 470 & 390 & ....do... & $10 \frac{1}{4}$ & Wire-mill machinery. \\
\hline 61 & $\begin{array}{l}\text { 3-cylinder, vertical, single- } \\
\text { acting, 4-cycle. }\end{array}$ & 2 & 350 & 275 & $\cdots 0$ & 24 & Machine shop and lights. \\
\hline 62 & $\begin{array}{l}\text { Two 3-cylinder, vertical, and } \\
\text { one 2-cylinder, horizontal, } \\
\text { single-acting, 4-cycle. }\end{array}$ & 3 & 710 & & $\begin{array}{l}\text { One, belt drive; } \\
\text { two, direct con- } \\
\text { nected to gen- } \\
\text { erator. }\end{array}$ & 10 & Shops. \\
\hline 63 & 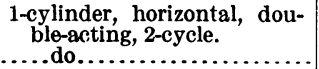 & & $\begin{array}{r}500 \\
1,500\end{array}$ & 500 & $\begin{array}{l}\text { Direct connected } \\
\text { to line shaft. } \\
\text { Direct connected }\end{array}$ & 24 & Paper-mill machinery. \\
\hline 65 & 1, single- & 3 & 700 & & $\begin{array}{l}\text { to generators. } \\
\text {...do.............. }\end{array}$ & $i 24$ & $\begin{array}{l}\text { Street-rallway service. } \\
\text { General manufacturing }\end{array}$ \\
\hline 66 & & 4 & 540 & 400 & $\cdots$ & 10 & Machine shop and light. \\
\hline 67 & $\begin{array}{l}\text { Horizontal, single - acting, } \\
\text { twin engines. }\end{array}$ & & 1,220 & & 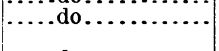 & 16 & Street-railway service. \\
\hline 68 & $\begin{array}{l}\text { 2-cylinder, tandem, double- } \\
\text { acting, 4-cycle. }\end{array}$ & 5 & 1,750 & 300 & do & 24 & Central power station. \\
\hline 69 & single-acting.... & 5 & 800 & $800+$ & do & 14 & Shops. \\
\hline & 1908. & & & & $\begin{array}{r}g \\
h \\
\text { hou }\end{array}$ & & s, one 6 \\
\hline
\end{tabular}


PLANT 1.

1906.

Difficulties.-Plant absolutely worthless for intermittent service required by a gristmill run on the basis that this is.

Remarks.-The owner of the mill believes that he was induced by misrepresentations to buy the plant. The agent claimed that it would be just the plant for varying demands; that it would fill the bill exactly.

He believes thoroughly in this type of power for continuous service or for ten hours daily, but finds it worthless for his use. He fought payment a long time, but settled rather than have a lawsuit. He wants to get rid of the plant, and says that he has written the company many times trying to get them to take it off his hands.

He believes that the company has no men competent to install and operate plants. He said that the company might have installed a plant in the neighboring town if they could have started his without difficulty, but it took them so long to get his running properly that the other people would have nothing to do with it. He believes that the company is hurting itself seriously by its methods.

\section{PLANT 2.}

1906.

Difficulties.-Serious clinkering; producer well filled with clinkers after each day's run; large quantities of clinkers taken out every night; operator says that he sometimes gets coal that does not clinker badly. The plant fails to respond to the variable-load demands, so the operator has to help out with city gas.

Remarks.-The operator thinks the plant uses 30 horsepower when running full. This load comes on suddenly at times. He thinks the engine can do the work, but does not get gas enough from the producer. Somebody has told him that the producer was too small for the work demanded of it.

During my visit the operator kept jumping constantly from the air compressor to the city gas valve, admitting more or less gas to the engine as the occasion required. He also had to vary his air supply continually to secure proper mixture. He practically had to nurse the plant along at all times.

I noted that he knew nothing of the theory of the working of the plant, and further that he knew nothing of the construction or arrangement. The air inlet valves to the producer were both closed, so the engine could draw little air or steam through the producer. He did not know that he had any steam, and if he did have it did not know where it went or where it was supposed to go. He usually had to shut down at noon in order to blow his fires to secure gas for the afternoon run. This blowing process requires about an hour.

My impression was that the engine was actually running on city gas-was doing the work required and incidentally "dragging" the producer besides. I think the producer was furnishing very little if any carbon monoxide. The engine must have been pulling some air through the producer, probably through cracks around the doors and plugs, but it was not getting its air through the proper channel. I believe little or no steam was getting into the fires. The producer was too hot.

The indications were that the producer was well filled with clinkers at the time of my visit.

The previous month's city gas bill tends to verify the above conclusions, as it amounted to $\$ 60$, according to the operator. He claimed that there had been months when the city's gas bill was only about $\$ 3$.

The plant was installed either in December, 1905, or in January, 1906. The present man has been operating it seven months. He claims that the plant was put in with the understanding that it would cost only $\$ 1.50$ to operate it, as the man who attended 
it could work on other things, etc. He claims that at the present time it is costing per day $\$ 1.50$ for coal, $\$ 2$ for gas, and $\$ 2.50$ for service. I believe that the prices for coal and service are somewhat overstated in this estimate. The engine had been running for three years and, he said, "without even having a screw-driver put to it." It seemed to be working fairly well, although with the erratic conditions that prevailed it was somewhat difficult to determine this point. The producer is charged with fuel three times every day-morning, noon, and night. The foreman of this plant seemed well satisfied with the uniformity in the running of the plant as far as he had noticed. The owner of the plant was not there.

PLANT 3.

1906.

Difficulties.-The operator said there were no difficulties. The plant ran very steadily during my visit. I understood there was some difficulty when the plant was first started, two years before, but the present operator, who had been with the plant about a year, claimed to have experienced no difficulty whatever.

Remarks.-The operator reported that he found considerable differences in the various loads of coal delivered to the plant, one load causing no trouble from clinkers and the next load giving considerable trouble. He regarded the producer as too small for the engine and the load carried. He feft that the producer should be large enough to require charging only every two hours without letting the bed get low. He asserted that there had been no shut-downs of the shop on account of the producer plant during his year of service. One of the office force whom I interviewed seemed perfectly satisfied with the operation of the plant.

\section{PLANT 4.}

1906.

Difficulties.-There was no difficulty at the time of visit, although there had been some from clinkers when the plant was first installed.

Remarks.-The plant has been running ten months. The owner wanted a producer plant installed without any cost to himself until it had been run thirty days. He said that most of the companies wanted one-third on contract, one-third on shipping, and one-third when installed, without even proving the possibility of running successfully. He says that he finally found a company that would be glad to install the plant without a cent until after thirty days of successful running. He took up the offer at once, and the plant proved entirely satisfactory for thirty days.

About ten days after the contract period-that is, forty days from the time of installation-they had considerable trouble. He found that the operator sent by the producer company knew no better what the trouble was than his own man. Finally they found that the trouble was caused by a bridge of clinkers. After that experience the plant ran very satisfactorily. The owner is very enthusiastic about the plant and would not do without it. He said that the plant cost him 35 cents per day of ten hours, as against $\$ 2.80$ per day with city gas.

\section{PLANT 5.}

1906.

Difficulties.-Trouble is said to be with the engine and generator rather than with the producer. The engine is undoubtedly too light for the load carried, and its construction is not suitable for producer-gas work, which accounts for the change of engines which was being made at the time of my visit. City gas is used in starting the engine, and in case of emergency to help out the producer. With the new engine it is thought that the use of city gas will not be necessary. 
Remarks.-If the present installation turns out as expected, the manager said he would increase the capacity as rapidly as possible. They want to use bituminous coal if possible, and would like a producer for this purpose. The fuel used for this plant at the time of my visit consisted of one part Pennsylvania buckwheat anthracite and two parts semianthracite from Bernice, $\mathrm{Pa}$.

The engineer said that he could regulate the height of the clinker bed at will with this combination of fuels. Another semianthracite coal which has been used to some extent is known as Spadra, Ark. When I visited the plant in the evening, a limited amount of city gas was being used to keep the engine up to full steady load.

\section{PLANT 6.}

1906.

Difficulties.-No difficulties if the plant is properly handled and supplied with proper coal.

Remarks.-The owner claims that the success of the plant depends entirely upon the method of handling the coal used. He says the producer company knows nothing about running this plant. His own company had to study the plant and had to run it. They got no help from the producer company. He further states that other plants of the same make have failed simply because of lack of ability and intelligence on the part of both the people using the plant and the producer people. He thinks he could make a great thing out of the producer business. He is exceedingly enthusiastic over his producer installation, but he does not feel that any of the credit is due the producer people. The credit belongs to himself and his company, who run the business and are interested in having things right.

The owner wants a specified anthracite No. 1 pea; can run on other coals, but has trouble with clinkers, and more work is required in operating.

The installation impressed me as excellent. The room was clean and well cared for.

I was told that the total water cost for this plant was equal to the coal cost.

1908.

The owner of this plant says his plant does fairly well, but that it is not all that it should be. He feels that he would have been better off had he waited until the present time before installing the plant. By so doing he would have had the advantage of the many improvements made during the last three years. With his plant there is too much that gets out of fix; first it is one thing, then another. Nevertheless he keeps the plant running and is satisfied that it furnishes cheaper power than any other he can get. He says that if he had not had a skillful operator the plant would have been down and out long ago. During the inspection the engine was running very steadily but with comparatively light load.

\section{PLANT 7.}

1906.

Difficulties.-Have to look out for tar in the valve stem. No trouble with producer at all; had a little trouble with the engine just at first.

Remarks.-The owner stated that 10 horsepower on gasoline cost $\$ 1.20$ per day of ten hours. He claimed that this plant, using only 40 to 50 horsepower, saves him $\$ 1,500$ per year over any other type. He figures that it costs him a bit over a dollar per day of ten hours for 50 horsepower. He says his average cost is 80 to 90 cents per day.

The plant was put in in June, 1905. The owner says he would not take $\$ 10,000$ for it if he could not get another like it. He thinks little of the ability of the man sent out by the producer company to install the plant. There were two or three men in the plant at the time of my visit who could operate it with perfect ease. 
It was running very nicely during my visit and was not tampered with in any way. A 14-horsepower planer was suddenly thrown on. The engine slowed down a bit but picked the load up well. The engine is started by compressed air. City gas is connected for use in time of emergency, although they claim that it has not been turned on for months.

I was told that the installation of this plant has brought the insurance well down.

1908.

The owner of this plant is a thorough believer in producer-gas power. They have had considerable trouble and many annovances from the plant installed, but the operating expenses are far below those for any other type of power. A year's cost record shows that during this time the profits from the sale of bale shavings were sufficient to pay for the coal, oil, waste, and all repairs on the gas engine. Had the steam plant been in use it would have consumed all the shavings made in the plant and in addition he believes as much coal as is used at present would also have been required. Further than this, a steam plant would require the services of a licensed engineer and a fireman.

Some difficulty has been experienced with the engine owing to the fact that it is not up to the specified rating. The conditions under which it operates are trying. It is belted to a 150 -foot line shaft and various wood-working machines are thrown on and off at frequent intervals. The gas which the engine is getting is probably not very good, and further than this the engine is seriously overloaded. During this inspection it back-fired frequently, and whenever large machines were thrown on the speed was seriously reduced. The owner, however, is sufficiently satisfied to contemplate the installation of a larger plant.

\section{PLANT 8.}

1906.

Difficulties._- "All kinds;" plant not running. Runs at times, not at others. Clinkers badly, and the operator finds it impossible to get the blast of steam through the bed. The operator seemed to think that with a clean producer (he was just cleaning out) and with new coal they could probably handle the plant without further trouble. Up to the present time (the plant had been installed eight months) it has done little.

The engine igniters had to be filed every day. They seemed to be very soft, and looked pounded as though the spring was too strong.

Six inlet valves have been broken during the eight months.

The engines are of the gasoline type, converted.

Remarks.-The operator says that he can start the plant in twenty or thirty minutee at times, but not at all at other times.

The operator seemed to believe producer gas to be the coming power, but admitted that he did not know how to handle it at present. He seemed to think that the producer company did not know much more about it, as the man sent to erect the plant had difficulty in operating it. He said they did not seem to have competent men to put up and start the plant.

My own impression in this case and in that of plant 1 led me to believe that the manufacturers were not giving proper attention to their plants. As soon as they secure the money they seem to let things run along without any further attention.

\section{PLANT 9.}

1908.

The praprietor seems perfectly satisfied with the plant and says that he pould not exchange it for any other type of plant which he knows. This producer has been in operation one and one-half years, and in that time the fire has been out three times 
only. They find the plant easy to start every morning and also find that it requires little attention. They have at times had some trouble with the igniter circuit, but the owner considers this his own fault. They experience no trouble with blowholes and have never had any trouble with clinker; the ash, which is apparently free from carbon, looks about as fine as wood ash.

\section{PLANT 10.}

1908.

The gentleman interviewed was very strong in his denunciation of this plant. He stated that it had never run over a month at a time and that they had not been able to run it at all for the last six months. He seemed to know no specific trouble save that they had broken three crank shafts on the engine, but his feeling is that the whole plant is no good. He stated that others of the company who were not present could give a long list of troubles. He also stated that the producer people have themselves started the plant several times, but after running a few days it would cease operations entirely.

Inquiry from outside parties who own similar plants with which they are well pleased gave the impression that the whole trouble is lack of intelligent operation and care.

\section{PLANT 11.}

1908.

Difficulties.-There were difficulties only when the plant was first installed, due entirely to lack of knowledge on the part of the owner and operator.

Remarks.-One of the proprietors stated that he would not ask for a more reliable or more economical plant. Before this installation the factory was run by means of gas engines using city gas. The gas bill averaged $\$ 800$ per year. With the present installation the fuel cost for the first year has been approximately $\$ 200$.

The engine is provided with two igniters. During the operation of the plant this precaution in providing an extra igniter has prevented shut-downs on three different occasions.

The ash contains considerable unburnt fuel. The grate is cleaned every morning. It is stated that it is during this cleaning that the coal is taken out with the ash. When they have time this coal is sifted out of the ashes, but during much of the time no attempt is made to save this fuel.

\section{PLANT 12.}

1908.

Difficulties.-The chief engineer stated that although they had numerous minor difficulties at the start they got along very well and at the present time are securing very satisfactory service.

Remarks.-The plant has been in operation one and one-half years. The business manager of the firm says he is thoroughly satisfied with the installation, but stated that he did not come in to contact with the details of operation. The points which come to his attention are the cost of fuel and repairs and the failures of the plant to run. In these particulars he says the plant is all right.

Apparently about 20 per cent of the fuel charged into the producer appears in the ash, but as the plant is using only approximately 700 pounds of coal per day, they find it hardly worth while to attempt to save the good fuel that passes out with the ash. The fire is thoroughly cleaned each morning. It is during this cleaning process that most of the coal passes through the producer. The fire has not been drawn for three months. On the average three-quarters of an hour is required each morning to put the producer in working condition and get the engine under way. 


\section{PLANT 13.}

1908.

This plant was not in operation at the time of inspection. The cause for the shut down was given as a broken belt. A steam pump was doing the work at this time. New settling basins have just been installed which are much higher than the old. This increased head is said to be too much for the gas-engine plant, so that the gas engine has been unable to handle all the work and it has been necessary to help out with steam pumps. There has been some talk of installing a larger producer-gas plant in order to handle the entire output.

Ashes are removed from the producer about every two hours, and owing to the demands on the plant the engine slows down considerably at such times, but picks up immediately. By this method of operating continuous service can be maintained, although the power developed by the plant varies considerably, owing to the periods when the speed of the engine falls off. The engine is usually run continuously for six days, but at times it is kept in service for two weeks. The kind of service that proves satisfactory for a pumping station might be quite unsatisfactory in other types of installations.

\section{PLANT 14.}

1908.

This plant is operated by an enthusiastic young man who apparently understands the principles of his plant thoroughly and is getting excellent results. He says there is nothing like a gas-producer plant for him. When he first began operating he had some clinkers, but by varying the quantity of water admitted to the vaporizer he finally found a point where no clinker seemed to be formed. Since this time he has been able to keep his plant practically free from clinkers. He experiences no difficulty when removing the ash from the producer with a normal load on the engine.

\section{PLANT 15.}

1908.

This plant has been in operation about one year and has given little trouble. It was not in operation at the time of this inspection, as the engine had just been sent to the factory for reboring the cylinder. The representative of the company interviewed thinks that the engine has been allowed to run for some time with little or no jacket water, owing to carelessness of the operator. He stated that he considers the outfit all right, and that he would not hesitate to put in a producer plant for any power requirement.

\section{PLANT 16.}

1908.

This plant has been in operation for five years. Both members of the firm say they could have nothing better or more reliable. During the first year they had considerable trouble and the manufacturer could not seem to help them out to any extent. The producer company threw the blame on the engine company and the engine company blamed the producer company. Finally the owners agreed to disregard the suggestions and advice of the manufacturers entirely, and started in to work out for themselves proper methods of operating. After numerous experiences they determined on methods that have been giving satisfactory results. They feel that they are still gaining information and are developing more confidence in the reliability of such installations. In building a new fire they find it quite simple to have the load on the engine within forty minutes after lighting the match. The firm has recently enlarged its shop and expects to put in a larger power plant. They say that they will not for an instant consider any other than producer-gas power. 


\section{PLANT 17.}

1908.

One of the members of the company stated that they are learning the methods of handling this plant so that they now like it very well. For the first year or so it gave a great deal of trouble, but this they attribute to their lack of operating knowledge. The plant has been in three years and for the past year and a half has been run by an ordinary laborer. During the first year there was considerable trouble in clinker, but of late there has been no such difficulty.

\section{PLANT 18.}

1906.

Difficulties. - The engineer said there were no difficulties at present, but stated that as this was an early type of producer he found it necessary to make several minor changes in the steam-supply pipe, etc., to secure good operation.

Remarks.-Minor fluctuations in the speed of the engine were noted. The engineer claimed that this occurred only when the engine was under heavy load. My impression at the time was that these fluctuations were due to variations in the quality of the gas. They were not, however, serious or frequent.

Electric lights were thrown on and off without apparent fluctuations of the engine. The light was fair in quality and steadiness.

\section{PLANT 19.}

1906.

No difficulties are had with this plant. It had been running since February, 1906, and had never been shut down on account of any failure in the operation of the plant. They had been troubled with clinkers only once. The owner advises the thorough cleaning out of the generator every three months. He said that without counting the cost of water in either case steam power costs him $\$ 100$ per month, while the cost of operating the present plant is less than $\$ 25$ per month. He had not paid a cent for repairs.

The large producer plant was bought in order to have sufficient power for a second engine, if desired later.

The owner stated that he had operated many steam plants and knows steam thoroughly. He is exceedingly enthusiastic regarding the operation of his producer plant. He said that every manufacturing establishment in the vicinity has watched the producer installation very closely, believing it to be a foolish venture, but now others are thinking of making similar installations. The men in the shop are constantly being asked by outsiders if they haven't had to shut down yet.

There was no apparent noise of the exhaust in approaching the plant. An exhaust pit is used. There was no more noise than with the ordinary steam plant of the same size and nothing visible, such as smoke, steam, or chimneys. Upon approaching the plant I was very much in doubt whether the producer was running. The installation is very neat. The plant was not touched during my visit and was running well.

\section{PLANT 20.}

1906.

The plant had been operating one year without any difficulties. The engineer stated that during the year they have been shut down only three hours, the one time being due to a water leak in the engine cylinder head.

The engineer has entire charge of all machinery, etc., including the sewing machines. He employs a boy, who attends to the packing and shipping of the goods, to feed the fuel into the producer and poke the fire occasionally. They intend to enlarge the plant to 150 horsepower. 


\section{PLANT 21.}

1906.

The plant was not running when visited. It is a new plant, erected in the spring of 1906, and presented an excellent appearance. The engineer stated that the company that installed the plant never instructed any man definitely about running it. He finds himself able to run it at times, but not at others. He never knows whether he is to get gas of good quality or not. After it is once started he says it runs well, but, as he puts it, the fact is that he knows nothing about running it and has never been shown. He seemed to be an able, intelligent man, and desired instructions.

The man who erected the plant is reported to have gone around the corner of the building every time he consulted his blueprints for fear the engineer and others would see them and gain some knowledge of the construction of the plant. At other times the blueprints were kept locked up. I was informed that an operator of a similar plant in another part of the country was sent to this plant later and operated it with no difficulty.

Compressed air was used for starting the producer-gas engine. This air was pumped by a gasoline engine, which at that time was pumping water, but in regular operation the air is compressed during the run and kept in reserve.

The blast for starting the producer was furnished by a small blower, driven by a small gasoline engine installed for the purpose.

\section{PLANT 22.}

1906.

The operator says there are no difficulties. He likes the plant and is anxious to get all the information possible in order to equip himself for the proper handling of such plants. I was much pleased with his appearance, ability, and enthusiasm.

The fuel used, anthracite. No. 1 pea, looked dull and poor, but seemed to work well. There was also a pile of bright anthracite. The operator said that the mixture of these two coals caused serious clinkering. He also asserted that the reuse of partly burned coal from the generator produces clinkers.

\section{PLANT 23.}

1906.

The engine was reported as worthless. The plant was installed in January, 1906, and ran about half of the time for four months; then the engine broke down and has not run since. At the time of my visit the power was furnished by a steam engine. They may possibly get back to gas if they can find a good gas engine.

The engine was not designed for producer-gas work. In fact, its only merit, in my opinion, was its low cost. The use of such engines is a serious setback to the success of producer installations.

\section{PLANT 24.}

1906.

In recent installations for a guaranteed service of twenty-four hours per day this producer company is putting in two gas generators, as they find it necessary to draw the fires from one generator each Sunday; that is, once a week.

\section{PLANT 25.}

1906.

The plant had not been in operation for several weeks. Several men from the producer company had just overhauled the plant. It had been in only a short time, but the producer was being relined. New bearings were being put in for the engine crank shaft, etc. One of the men remarked that the plant was in terrible shape and 
laid the blame to whoever had had charge of it. Inquiry regarding the operator of the plant indicated that he was incompetent, having left the plant to a helper who knew little or nothing of its requirements.

\section{PLANT 26.}

1908.

Difficulties.-Considerable trouble is experienced in this plant from clinkering of the fuel. This has caused several shut downs, although at times they are able to run for several weeks without any inconvenience.

Remarks.- This plant had shut itself down just before inspection. Upon examination the producer was found to be badly filled with clinker. Apparently the cleaning had not been properly done for several days. The works are entirely dependent upon the producer plant for power and any interruption in the service means considerable expense. At one time the plant was out of commission for three days. At another time the engine stopped during a heat in a cupola, cutting off the blast. The entire charge was dropped and the day lost. The superintendent says their experience leads them to feel very uncertain regarding their power. Apparently the greatest trouble at this plant is a lack of operating knowledge.

\section{PLANT 27.}

1906.

The producer operator whom I saw likes the producer, as he can sleep and let it run itself and can go out of doors when he pleases. He had just smashed two holes in the engine cylinder head, so that the plant was shut down for repairs. He said it would run from one hundred and twenty to one hundred and twenty-five hours without shutting down, and then required about six hours for cleaning, etc.

The producer had been installed about two years; the present engine about four months. The plant was provided with a patented process, which had been in operation only four weeks. The producer operator liked this new process because he could sleep for six hours without charging the producer, whereas with the ordinary method he had to charge every two hours.

\section{PLANT 28.}

1906.

Difficulties.-All kinds of difficulty were experienced at first; changes have been made ever since the plant was installed; a new 2 or $2 \frac{1}{2}$ inch top plate was put on in place of the $\frac{5}{8}$-inch plate used by the manufacturers. The superintendent said the vaporizer never made steam, so he introduced a steam pipe from the boilers to help out.

The plant was shut down at the time of my visit on account of clinkers. The operators must have taken out 2 bushels of clinkers in large masses. The superintendent said that they had had no such trouble in three months, as his former operator handled the plant well, but they had to dismiss him. It seemed that during the last days of the service of the former operator the plant was not properly cleaned and the clinkers began to accumulate.

Remarks.-The superintendent said that the gas-producer company showed no interest in the plant whatever; he would not have the plant if it were out, but as long as he has already put it in, he is making the best of it. He is changing it in every way possible and claims that it has been running well for three months. The former operator was paid $\$ 1.65$ per day.

The superintendent believes in producer-gas plants, but not in the one installed by this company. I was unable to learn of any other installation of this make of producer. 


\section{PLANT 29.}

1906.

This plant had been running about nine months. The plant is reported to work splendidly since special charging equipment was added, although before this addition some back firing and preignition were experienced.

According to the superintendent the company is greatly pleased with the results of the plant at present. Before the addition of the special equipment the compression carried by the engine was 120 pounds. At present they are carrying about 200 pounds.

1908.

This plant was not installed for continuous operation. It is used only for the purpose of testing engines manufactured for operation on producer gas. Its service in this capacity has given satisfaction.

\section{PLANT 30.}

1908.

The owner of this plant states that they had many minor difficulties to overcome at the start, but these he feels were due to ignorance on his part more than anything else. At present he is very well satisfied with the service and regards the power as the cheapest he can possibly secure.

\section{PLANT 31.}

1908.

This plant has been in three years. According to one of the members of the firm it has given all kinds of trouble. He found it impossible to get an experienced man to handle it. He finally taught an Italian laborer to do the work, and for nearly two years he has handled the plant. They are getting much better satisfaction from it now than ever before, but they feel much in doubt regarding the reliability of the engine. Apparently the engine has not been kept in good condition. The crank shaft needed lining up and the crank-pin bearings were apparently loose. The shuttingdown hour came during the inspection, and it was noticed that the Italian operator thought more about getting away in a hurry than about putting his plant in proper condition. The company has an electric wire run in from an outside source which can furnish current whenever the gas fails.

\section{PLANT 32.}

1908.

The superintendent is very well satisfied with the plant. It has been in operation over three years, and during that time it has not been shut down three hours owing to any fault of the engine or producer. The operator is an exceptionally good man and one in whom the superintendent has confidence.

The producer is cleaned thoroughly every Friday night and a new fire is built up at once, so that it is in readiness Saturday morning. The operator says that the producer would run much longer without cleaning, but by this systematic method of handling the plant he keeps his producer in good condition at all times, and no clinker can accumulate for any length of time even if some should form.

The operator considers the stand-by losses as practically nothing, but they are probably somewhat greater than he estimates. The operator allows himself one-half hour each morning for putting the producer into condition and getting the engine under way. He finds that it takes no longer to start the plant on Monday morning than on any other morning during the week.

$$
68942^{\circ}-- \text { Bull. } 9-10 \longrightarrow 4
$$


Although the producer is rated as 120 horsepower, the operator does not like to run it above 100 horsepower capacity except for short periods, as he finds it very erratic if worked too hard.

\section{PLANT 33.}

1908.

The manager of the firm considers the plant very satisfactory. It has been in operation for five years and he has never observed any serious trouble. He regards the plant as reliable and economical. Before making this installation they used a 40-horsepower gasoline engine, with a fuel cost amounting to $\$ 7$ to $\$ 10$ per day. He says they are now getting more power with this present plant on less than one-half ton of coal per day.

The engineer in charge of the plant said that he had had no experience with producers before operating this one. When the plant was first installed he had trouble from time to time, but gradually overcame this in his own way, and now feels as much confidence in this plant as he would in any steam plant. They have from time to time been obliged to help out the plant with city gas, but the engineer stated that no city gas had been used for three years. They use any pea anthracite, provided it contains but little dirt. As a rule, the fire is drawn every Saturday night, the producer thoroughly cleaned out, and a new fire started. If, however, the coal which is being used happens to give trouble by clinkering, he draws the fire in the middle of the week as well as at the end. He considers it a very small matter to draw a fire, clean the producer, and build up a new fire. He regards it as about the same as cleaning a boiler furnace, save that it is necessary to delay the cleaning until the close of the day's work.

\section{PLANT 34.}

1906.

Difficulties.-The "bell" or "thimble" burns out about every six weeks. The last period was only one month. The producer was shut down during my visit on this account. The engine was running on city gas. The cast-iron thimble actually melts, which indicates a very high temperature and probably lack of moisture in operating the producer. As the plant has its own foundry, they are able to cast their own thimbles and keep extra ones on hand.

Remarks.-They say they have no trouble from clinkers and never draw the fires save when the thimbles burn out.

The engine ran poorly on city gas; it back fired badly and the speed seemed low. The operator claimed that the speed was always 50 revolutions lower on city gas than on producer gas.

The plant began operating, I believe, in February, 1906.

\section{PLANT 35.}

1906.

Clinkers caused difficulty. The plant ran nicely on charcoal costing $\$ 11$ per ton, but failed on coal costing $\$ 4$ to $\$ 5$ per ton. The superintendent said the engine was all right, but the producer no good. The plant had been in one and one-half years, but had not been run for two months. They claim to have received no assistance from the manufacturers, save a little from one of the men who erected the plant.

They had an operator who could handle the plant very successfully, but he left two months before my visit and they had not been able to run since. After he left their employ he came back once or twice and ran the plant successfully, but the other operator could not handle it. It clinkered badly after two or three days, so that it was impossible to run. 
They state that at one period the plant ran successfully without cleaning for eleven hours per day for three weeks, but upon investigation they found that the operator had used two-thirds charcoal.

They say that the failure of the plant has killed the producer business in this region for that producer company, and has seriously hurt it for all others.

I was told by disinterested parties that the chief difficulty with this plant is the fact that the owners will pay only $\$ 40$ per month for a man to run the whole plant, and will not pay anybody to put it into proper shape for successful operation.

A 125-horsepower motor, run by city current, is now used in place of the gas plant.

\section{PLANT 36.}

1908.

Difficulties.-Formerly had considerable difficulty with clinkers, but this has practically all been overcome. There were several other trials when the plant was first installed, but gradually the difficulties were overcome. The manager of the company seems enthusiastic about producer gas.

Remarks.-A considerable portion of the gas is used in fire pots for heating soldering irons. The gas is drawn from the producer by an exhauster and forced into the pipe system leading to these pots.

The manager stated that before the installation of this plant their bill for power and city gas was $\$ 300$ per month. The same service now costs $\$ 150$ per month.

City gas connections are made to the engine, and it was learned that this has to be used at times to help out the producer plant. It is probable that the operator is not getting the maximum return from the producer.

At least 25 per cent of all the coal charged into the producer passes through unburned. The ashes are, however, sifted, and this coal is used under the boiler in the winter time.

\section{PLANT 37.}

\section{8.}

The superintendent in charge of shops and power stated that the producer has given very little trouble, but the repairs on the engine have cost enough to offset any saving in fuel that may have been made over a corresponding steam plant. He feels that there is a chance for improvement in gas-engine construction. He had some difficulty in getting a man to handle the plant. The man now employed to look after both the producer and engine is paid $\$ 12$ a week. Some clinkering is experienced, but is not serious. The fire is drawn only about once a month.

\section{PLANT 38.}

\section{6.}

Diffeulties.-The plant was installed about Christmas, 1905. It was three months before they could operate it. It clinkered badly. The top of the generators burned out and had to be rebuilt.

More or less difficulty was had with the engine also. The fly wheel is 180 pounds out of balance. They say no credit is due the manufacturers that the plant runs at all.

Remarks.-The engine is located about 135 feet from the producer. A 125-horsepower producer was installed at first. A second and larger producer had to be installed so that they could be worked alternately if desired. They were both running at the time of my visit.

For the first three months the plant resulted in heavy loss to the company, but the manager believed that they would make it up by the end of twelve months, owing to the economy of the plant. He says they would not install such a plant if they had to depend upon it, but they can change to steam in six hours if driven to it They usually start the plant by steam until it is in full operation. 


\section{PLANT 39.}

1906.

The plant seemed to run fairly well. According to the statement of the owner, there was some trouble at first. They have some trouble with the magneto, the spark being cut out at times. This happened while I was present, when they shut down the plant.

They have some trouble with poor gas occasionally. Some weeks there are no shut downs, while at other times there will be two or three in one week. These are, however, of short duration.

Occasionally they have been troubled with clinkers.

\section{PLANT 40.}

1908.

$\Lambda$ member of the firm reported that the plant had been in operation fifteen months, during which time it had never failed. He said that it used very little coal, and he considers it the cheapest kind of power. At the time of inspection the factory was shut down for two weeks, and the plant was consequently not running.

The operator seemed to be exceptionally well informed regarding producer gas. The plant, like many others, has a producer of large capacity operating on a low load factor. The demands in this case amount to only about 30 per cent of the capacity of the plant. After talking with the operator I was convinced of his ability to handle the plant with ease, and it is not difficult to see why the members of the firm feel great confidence in their power plant.

\section{PLANT 41.}

1906.

Difficulties.-There were troubles at first; the producer was too small; they had to get a larger producer; the valve cams on the engine were wrong; the manufacturers would not show them anything.

The producer company claimed that all the troubles were due to the fact that a steam engineer was in charge of the plant. The owner was satisfied that this was not the case, so he got a larger producer, reground the cams, had the valves reset, and now has the plant running in excellent condition.

Remarks.-This plant was installed in January, 1906. A long time was spent looking into the matter. Minneapolis, Chicago, Philadelphia, etc., were visited in order to judge of various plants. The engine was what decided the choice. The manager does not like vertical engines, as he wants an engine so constructed that one's hands can be put on any part of it.

Some difficulty was experienced with magnetos.

They have had some trouble caused by the stripping of the thread of the enginevalve stems. This happened while I was present.

They are running the exhaust into the fire box of a vertical boiler to heat water and also to do away with the exhaust noise.

The engine was belted to a 150-kilowatt electric generator.

They handle the clinkers in the producer rather successfully with bent pokers. They have had to put extra holes in the producer for this purpose.

The plant is very neat and apparently is well understood.

\section{PLANT 42.}

1908.

The president of this company stated that he did not wish to be too enthusiastic about producer-gas power, as there are many minor difficulties to be overcome. He fieels that his plant is fairly satisfactory and thinks he can make it absolutely satisfactory in due time. He said that were he to build another factory he would not hesitate to install a producer-gas outfit for developing necessary power, 


\section{PLANT 43.}

1908.

This plant is used in connection with pumping stations. The water is pumped at a distance of about 12 miles and it is proposed to extend the line some distance farther. As the water supply is unlimited, no effort is made to economize in the use of water about the plant.

The operator stated that he has some difficulty in procuring a satisfactory lubricant for the engine crank case.

The operator feels that care is necessary in securing a proper kind of coal, as trouble has been experienced with certain coals on account of excessive clinkering. Ordinarily the fire is drawn and the producer thoroughly cleaned once a week, but at present this is being done twice a week. The operator feels that it is very important to keep the producer clean and free from clinker. He regards it as no hardship to dump the fire and start a new one. He says that he can get the producer in shape for his usual load in one hour after lighting the match. He believes thoroughly in gas producers, but says they will not take care of themselves, as some manufacturers try to make out.

\section{PLANT 44.}

1908.

This plant has been in operation nearly two years. The fire has been out but twice. It was drawn once to put in a new grate and at another time to examine the brick lining. The superintendent seems very well satisfied with the installation and feels that his plant is doing as well as any. He seemed careful not to mention anything against the system, but his casual remarks would lead one to believe that he thinks improvements might be made.

They claimed to have no trouble from clinker. The ash pile was comparatively free and clear, the few clinkers in the pile not being larger than the fist. There was, however, considerable unburned coal. This was said to be due to the cleaning which the producer received every morning.

\section{PLANT 45.}

1906.

Difficulties.-There is a good deal of trouble from back firing. At the time of my visit the electric generator was sparking seriously and burned out before I left the plant.

Remarks.-On the whole, the company seemed to be fairly well pleased with the results. The method of handling the producer was wasteful of fuel, as about onethird of the coal charged to the producer was taken out unburned in the ash. This mixture of ashes and coal was used on the walks about the plant.

\section{PLANT 46.}

\section{8.}

The representative of the company consulted stated that the plant had been in about two years, and that although they have had numerous difficulties these are being gradually overcome and at the present time the plant is giving fair satisfaction. The producer has never given any real trouble except that due to clinker formation when a bad coal is used. The engine is the first of its kind and naturally gave a good deal of trouble. The engine builders, however, made numerous changes and it is now working much more satisfactorily. He feels that in spite of the difficulties the gas-engine and gas-producer installation is the most economical power plant, and that in time all troubles will be overcome. 


\section{PLANT 47.}

1908.

This plant is running very satisfactorily at present. The engineer in charge feels that he now has the plant well in hand. He has confidence in it as a source of power. In the early days of the plant they had considerable trouble, but he feels that this is due to a lack of operating knowledge more than to anything else. The engineer in charge stated that he was a steam engineer and that he preferred steam, but that the economy possible with gas makes it necessary to learn to use it.

\section{PLANT 48.}

1908.

This plant has been in operation only six months and is one of the few plants with which no trouble has been experienced during the early operating period. The engineer in charge says that he has never had any experience with producers or gas engines until about a year ago. Although a steam engineer, he sees a great future for the gas plant and says it is useless to be prejudiced. He takes much pride in this gas plant. He is also in charge of three or four steam plants for the same company. The gas-plant installation is in duplicate throughout. Usually but one producer and two engines are in operation at any given time. Each engine has a city gas connection, but it is stated that this is seldom used and was put in simply as a precautionary measure. Part of the engines are run at a constant overload of 20 per cent. They seem to carry this without difficulty, and upon one occasion one of the engines carried this overload continuously for one hundred and sixty-eight hours. Usually the change of units is made more frequently. At the time of this inspection the engines were running very smoothly and with little noise. It was impossible during the casual inspection to detect any variations in speed.

\section{PLANT 49.}

1908.

Difficulties.-There were numerous difficulties when the plant was first started, due to clinkers, back firing, poor ignition, etc., but at the present time there is practically no trouble.

Remarks.-The manager feels that the plant is giving very good satisfaction considering the fact that producer-gas plants are so new. The two young men who handle the plant have, I believe, had no experience before taking this job, but they seem to be getting hold of the method of operating very satisfactorily.

\section{PLANT 50.}

1908.

The gas producer originally installed was a suction plant, but it has been cut up, patched up, and changed over in many details until it is now running as a pressure plant. The member of the firm consulted is much disgusted with producers and producer manufacturers. He apparently has his own ideas regarding the construction and operation of producer plants, which accounts for the many changes which have been made in the present installation.

\section{PLANT 51.}

1908.

This plant was installed a little less than a year ago. It is giving continuous service (twenty-four hours per day) in a satisfactory manner. A short time before this inspection carelessness on the part of a stoker disturbed some of the fire brick in the producer 
lining, making it necessary to draw the fire in order to make the repairs. Previous to this mishap the plant had been operating continuously over four months. Each Wednesday the load is reduced one-half, and during that time one engine can handle the load. In this way each engine has a day of rest once in two weeks. The igniters are changed and every part carefully examined. The superintendent of the plant is well satisfied with the operation.

\section{PLANT 52.}

1906.

Difficulties.-There are no difficulties now; those they did have, the owner stated, were due to careless operating rather than to inherent faults in the plant.

Remarks. - This plant has been in operation two and one-half years. Besides the gas used for power this plant also furnishes the gas for heating 150 irons in the ironing and pressing room. The heat is found to be steady and very satisfactory. They formerly used city gas, but find the present arrangement far more economical. They still have the city gas connections for the irons in the same pipe system, but have no occasion to use it.

They purify the circulating water and use it in another portion of the work.

I was told that cheaper fuel is used in the producer than under the steam boilers.

At present they are laying the foundation for the installation of another engine in addition to the present one.

The owner stated that although he regards the initial cost of such a plant as higher than the cost of a corresponding boiler plant, there is, in his opinion, economy in additions to the plant; that is, producers can be added without adding extra scrubbers, holders, etc., and thus have a reserve plant for less cost than a reserve boiler plant.

No odor of gas was perceptible in the ironing room. This gas is supplied by pumping; a rotary blower is used for the purpose; the pressure is low. The gas burned with a steady blue flame.

1908.

Difficulties.-There is no difficulty whatever when the coal desired can be obtained. When any coal that happens to be delivered must be taken difficulty with clinkers is frequently experienced.

Remarks.-The owner is very well satisfied with the plant, although numerous difficulties due to lack of knowledge arose during the early period of operation, and the repair expense at this time was considerable. His statement regarding fuel cost is to the effect that 1,700 pounds of coal used in the gas producer does the same work which was formerly done by city gas costing over $\$ 40$.

\section{PLANT 53.}

1906.

There were slight difficulties at first with mixtures, etc., but none now. The plant is very satisfactory. It has been running over a year. The engine is directly connected to a 150 -kilowatt electric generator.

They claim to have had no trouble from the action of sulphur. I noted occasional back firing in one end of the cylinder.

The exhaust is used for heating feed water for the steam plant. The gas engine is run in parallel with the steam engine.

There is no exhaust noise; they use large exhaust ports of special form, making the pipe connection "flaring" in such a manner as to accommodate the expansion of the gas.

The producer operator receives 20 cents per hour. 


\section{PLANT 54.}

1908.

The representatives seen feel that their plant is giving satisfaction and requires but little attention. They feel as much confidence in the reliability of the plant as they would in the steam plant. It should be stated, however, that the representatives are interested in the manufacture of this type of plant.

\section{PLANT 55.}

1906.

All kinds of difficulty were experienced with the old type of producer, which is now being torn down; no difficulty with the new type now in operation. This new producer is liked very much by the engineer. A second producer is to be erected at once.

There is no gas holder; automatic steam control is used. The engineer said it worked well. Steam pressure of 50 to 80 pounds is carried in auxiliary boiler.

The fires had not been drawn since the new plant was put in operation five months before. The engineer thinks the difficulties in most cases are due to the operator and methods used rather than to the plants themselves. He believes in the plant thoroughly; is interested and wants to learn.

The engine exhaust is run into a pit filled with broken rock; the noise is hardly noticeable.

\section{PLANT 56.}

1908.

Difficulties.-The plant has been installed about nine months. During the first two months, according to the owner, they had all kinds of trouble; clinkers as big as a barrel, poor gas, large coal consumption, back fires, etc., but these troubles seem to be past, as they have been overcome by experience.

Remarks.-The owner feels that producer manufacturers do not give sufficient and proper instruction when installing a plant. They leave too much for the purchaser to learn from his own experience. He says that at the present time he is undoubtedly using less coal than he would with an equivalent steam plant, but he is inclined to believe that this saving is offset by extra oil and labor which his gas plant requires. Before his purchase the producer representative made a strong point of the adaptability of the producer to cheap and low-grade fuels, but now that he has the plant in he finds that they are able to use only the best grades of coal.

The engineer in charge of the plant seems very well satisfied with the results they are securing and considers it an excellent installation. He says that all the trouble at the beginning was due entirely to lack of knowledge on the part of the operator and to an attempt to do many things which were not practicable. Another disadvantage at the start was the fact that the man employed on the producer was a cheap laborer with no knowledge of producer practice. These difficulties have been overcome, and the engineer says that he would not ask for a better plant than this has proved to be for several months past. The engine operator is regarded as a man of more than average ability and it is seldom that anything wrong develops in the engine room. The engineer stated that when the producer was in proper shape they never knew the engine to fail. He also stated that as a rule he could carry the load within two minutes after starting the engine.

\section{PLANT 57.}

1906.

There were no difficulties with the producer and none with the engine were mentioned, although the opinion seemed to be that some of the engines were not adapted to the work demanded of them. 
At the time of my visit these producers had been installed nearly seven and one-half years. From one the fires were not drawn for six years and ten months. The fire was drawn then in order to put a new top on the producer. The lining of the producer was found in perfect condition, and not a brick was renewed. It had been five years since the fire was drawn in the second producer, and the engineer stated that he did not know when it would be drawn, as there was no reason for doing it.

The economizer tubes fill after a time, so it has been customary to change these about every two years. The old tubes are cleaned and replaced two years later.

Engine $(a)$ had been installed two years, and has given entire satisfaction. It was running well when I visited the plant.

The two engines $(b)$ had been in over seven years. They were installed with the original plant. The engineer objects to the hit-or-miss governor on the engines.

Of engines $(c)$, two had been in six years and one five years. These were running satisfactorily while I was there.

Engines $(d)$ and $(e)$ are about 1,800 feet from the producer plant. Engine $(d)$ seemed to be helped out occasionally by city gas- "only occasionally," I was given to understand, but engine $(e)$ was run almost entirely by city gas.

The engineer was greatly pleased with the producer plant. He said that he experienced-no difficulty with the producers and that they gave excellent satisfaction. One producer was operated with automatic feed, but the other was not.

1908.

This plant has been in operation since April, 1899. In one of the producers the fire has not been drawn for over seven years and is in good working condition at the present time. The other producer gave continuous service for six years and ten months from the time of installation. At that time the producer was in good working shape, and according to the statement of the engineer could have continued in service but for the fact that a distributing plate in the automatic feed fell into the producer. This caused such damage that it was necessary to draw the fire. After necessary repair the fire was rebuilt and has not been drawn since.

The ashes are removed from each producer every other day, during the period of lightest load, when it is possible for one producer to carry the load. The ash pile was practically free from carbon and clinker. The engineer stated that he accepts any pea coal for the producer that does not contain an excessive amount of dirt and fine stuff. The engineer in charge of the plant has been with it about seven years. He is an enthusiastic gas-power man and believes that the cause of most producer failures is the lack of competent operators.

\section{PLANT 58.}

1908.

The operating engineer in charge of this plant says it has given no trouble from the start. A 300-horsepower Corliss steam air compressor runs by the side of the gas engine. The engineer states that the gas plant has required much less attention during the fourteen months that it has been operating than the steam engine. The superintendent is very well pleased with the plant.

\section{PLANT 59.}

1908.

The assistant superintendent believes firmly in producer-gas power. When asked if there was anything about the plant he would like to improve upon he replied that he knew of nothing about the whole equipment of which he would ask better service. He maintains that the success of a producer-gas plant depends in great measure upon the men operating it. If the man at the producer knows what he is doing and the engineer is equally well adapted to his work, there will then be little trouble. 


\section{PLANT 60.}

1908.

This plant has been in operation nearly ten months and is considered by the superintendent as very satisfactory. The superintendent has had some difficulty in securing competent men to handle the plant.

The coal consumption can probably be improved upon, as approximately 20 per cent of the coal charged into the producer passes through the grate unburned. The engine was operating very smoothly; in fact it is running as steadily as a steam engine. A portion of the time there is a heavy overload which has to be taken by the steam engine, but the gas engine and steam engine are run in parallel without difficulty. The superintendent thinks that eventually this steam engine will be replaced by a gas engine.

\section{PLANT 61.}

1908.

This plant has been in operation about a year and a half and it is giving excellent satisfaction. A new producer of 300 horsepower has recently been installed, having been in operation about three weeks at the time of this inspection. Before this last installation was made two producers of 150 horsepower each furnished the necessary gas. These have been in operation almost continuously since the installation of the plant and are in need of relining. The chief engineer feels so well satisfied with the plant that he says he would not hesitate to put in producer-gas power for any purpose.

\section{PLANT 62.}

1908.

This is an installation in the factory of a gas-producer manufacturer.

\section{PLANT 63.}

1908.

The president of the company feels that the secret of successful operation of producer-gas power plants is gas of uniform quality. In their business it is necessary to have constant speed regulation. They found this difficult with producer-gas engines, owing, he believes, to the lack of uniformity in the gas. He stated, however, that he would not hesitate to install a gas plant for any purpose in which absolutely constant speed is not required. He considers it a very economical power and feels that reliability depends largely upon the producer operator.

When the plant was first installed they experienced considerable trouble due to lack of knowledge. In his opinion, producer manufacturers fail to properly instruct operators of new plants. Since picking up the proper methods of manipulation they have had little difficulty and are well satisfied with the results which they are securing.

\section{PLANT 64.}

1906.

Only one engine was running during my visit; this seemed to be very steady in its operation.

Tar extractors were installed with this plant for operation in case bituminous coal should he used.

\section{PLANT 65.}

\section{6.}

Difficulties.-They have had some trouble from clinkers, also, I believe, some from lampblack.

Remarks.-The superintendent did not feel absolutely sure about the power. He seemed to be well satisfied with the plant on the whole, but did not feel that it is 
absolutely reliable under all conditions. He was somewhat doubtful whether, in increasing the capacity of the power plant, to add more producer-gas units or to put in a steam plant to supplement the present gas plant. He seemed inclined to the additional producer-gas units provided he became positive of the absolute reliability of such power for continuous service, twenty-four hours per day.

The plant was running well at the time of my visit.

\section{PLANT 66.}

1906.

Most of the water gas (200 B. t. u.) is used for forges, etc., power being a secondary matter-a by-product, as it were.

The producer (air) gas generated is of about $90 \mathrm{~B}$. t. u. heat value. The gas supplied to the engines is a mixture of the water and air gas in such proportions that its heat value is in the neighborhood of 115 to $130 \mathrm{~B}$. t. u. per cubic foot.

The manager likes the plant well enough but feels that perhaps they could get more out of it than they do.

\section{8.}

The works manager is on the whole very well satisfied with this plant. He encountered troubles at first, but after some experience lcarned how to overcome them. $\mathrm{He}$ does not feel that the producer manufacturers were able to give much help regarding the operation. The plant has been in nearly four years. The ash pile seemed to be small considering the amount of coal used. There was little real ash. The pile was composed mostly of clinkers varying in size from a man's fist to a nail keg, or even larger. There appeared to be very little carbon in the ash, but upon breaking up large clinkers numerous lumps of coke could be seen embedded.

The fires are drawn and the producers throughly cleaned each Sunday. On the whole the manager seems well satisfied with the plant, but feels that it is possible for them to get more out of it than they do.

\section{PLANT 67.}

1906.

The coal used is Pocahontas, which is delivered at the central station, and the various plants are supplied with the mixture as it comes from the central station. Owing to repeated handling the coal is reduced to a very fine condition.

The engine that was running while I was at the plant was pounding slightly. The engineers reported that they had broken exhaust levers occasionally, owing entirely to the carelessness of the operator.

The plant uses 34,000 cubic feet of water per day. Water is taken from the near-by brook instead of from the city service. The producer man was paid $\$ 16$ per week.

In operating this plant at the present rate water gas is made only three times per day, and then only for two or three minutes at a time, long enough to fill the holder. The water gas is by-passed and mixed with the producer gas. A small portion only of the former is used.

The people in the vicinity objected to the noise of the exhaust. Several devices have been used to reduce this. At the time of my visit the plant was using a pit filled with broken rock, which seemed fairly satisfactory.

The engineer says that the men about the plant were greatly pleased with the producer at first, as if with a new toy, but after the novelty wears off their interest flags. He says that the plant must be looked after and that there is a tendency on the part of the men to neglect it.

They have had occasional preignitions and back firing, but these have not been serious. 


\section{PLANT 68.}

\section{8.}

Although this plant is of the down-draft type, it is found necessary to "shoot the bed" only once in twenty-four hours as a rule, and sometimes only once in two days. The general manager of the company stated that the best coal obtainable is most satisfactory and economical, regardless of price. They have tried in this plant 20 or 25 different coals of a lower grade than that which they have selected as their best fuel. With the high-grade coal they usually operate one unit for two weeks, then cleaning it and operating the second unit during the second two weeks. With coals other than the kind especially selected for this plant they have usually found it impossible to run a unit longer than one week without cleaning. Some difficulty has been experienced in keeping the piston rods in such condition that they will not cut the stuffing boxes. Three of the engines are not regarded as satisfactory and are used only for carrying partial loads. They are apparently unreliable, as it was stated that they may run five minutes and they may run twenty-four hours. They require constant attention. The two larger engines are considered perfectly reliable. They were running with freedom at the time of this visit.

The first three years of this installation were marked by failure after failure. During this time apparently little help and few suggestions could be secured from the manufacturers. It was a question of working out the difficulties at the plant itself. At the present time and for the past two years the installation has furnished reliable power, and at last the company is beginning to overcome the unsavory reputation gained for the plant during its early life. They are now furnishing power for several manufacturing plants and light for several villages up and down the valley. The manager believes that producer gas is the coming power, and feels that it is now possible to put up installations that will prove entirely reliable.

\section{PLANT 69.}

1906.

The producer manufacturers have not been called upon for any assistance since the plant was installed in 1900 , but several changes have been made in the plant which have proved beneficial.

The gas-producer installation has been a process of development with this company, the original plant having been installed in 1900. One exhauster was run at that time by steam power and the other by a gas engine. After watching this gas engine for a time it was decided to try gas for power purposes. A tandem engine with rotary valves like those of a Corliss steam engine was installed. Grit would lift these valves from their seats and the engine gave serious trouble. Finally another type of engine was tried, and as it worked from the start with no difficulty, four additional engines of this make had been installed. They are expecting to install additional engines of the horizontal, double-acting type.

Straight water gas is used in many portions of the plant, but when low heats are required a mixture of $4 \frac{1}{2}$ parts producer gas (air gas) to 1 part water gas is used, giving a gas with a heat value of about $135 \mathrm{~B}$. t. u. per cubic foot. For the engines 6 parts of air gas to 1 of water are used, giving a gas of about 115 B. t. u. per cubic foot.

Gas power has proved exceptionally economical for this plant, as most of the producer gas which had to be made was wasted before the installation of the engines.

The company believes thoroughly in this system of power and each year more of the works is being supplied with gas power.

The plant requires proper care, which necessitates a good grade of men. For this reason the representative whom I saw believes that there is better economy in labor in a central power plant than in separate engine installations in various parts of the factory.

Every Sunday one engine is thoroughly cleaned and the inlet valves and the mixing chambers in the others receive attention. 


\section{DEDUCTIONS FROM VISITS OF INSPECTION.}

\section{The deductions made from the visits in 1906 were as follows:}

1. The plants as a whole are giving remarkable satisfaction considering the very brief period of development that has passed since the introduction of this type of power.

2. The most serious difficulty seems to arise from the lack of competent operators to run the plants rather than from defects or troubles inherent in the plants themselves.

3. Incompetent salesmen are undoubtedly to blame for serious misrepresentations and misunderstandings.

4. The neglect shown by some manufacturers in respect to their plants after they are installed and paid for has not been farsighted, and the failure of manufacturers to give the purchasers or operators of plants full information regarding their construction and method of operating has certainly been detrimental to the business.

At the present time (1909) the following modifications might be advantageously made in the above statements:

1. Unchanged.

2. This situation still prevails, although there are many more competent operators to-day than three years ago. Time will eliminate this difficulty.

3 . With the stronger companies this situation is greatly improved.

4. Experience has shown that such neglect produces serious troubles and financial loss to the manufacturer, and a very decided change for the better has developed in the last few years. There are, however, a few small concerns still operating in the producer field on what may be considered a false basis.

\section{NUMBER AND DISTRIBUTION OF PRODUCER-GAS POWER PLANTS IN THE UNITED STATES.}

Although a few scattered installations are reported as having been made prior to 1900 , the period of systematic and general application of producer-gas power in this country seems to have begun in the past six or eight years.

Owing to the fact that the dates of installation of many plants are not ascertainable, it is impossible to present the exact rate of growth either in number of installations or in horsepower. The relative rate is, however, approximately shown by figures 2 and 3 , the data for which were secured from 375 installations. The points for the year 1909 are estimated from the returns for the first five months. These points have been checked by two or three methods and indicate only the normal increase established by the rate of development before the business depression of 1908 . It is probable that the actual figures for the entire year may exceed those indicated.

The unceasing demand for information regarding producer-gas power plants in actual commercial operation has led to an attempt to present at this time a reasonably complete list of such installations, together with such particulars as seem to be especially desired.

Application for such lists was made to 43 companies. Several replied that they manufacture producers for metallurgical work, but have not entered the power field. $\Lambda$ few failed to respond at all. 
웅

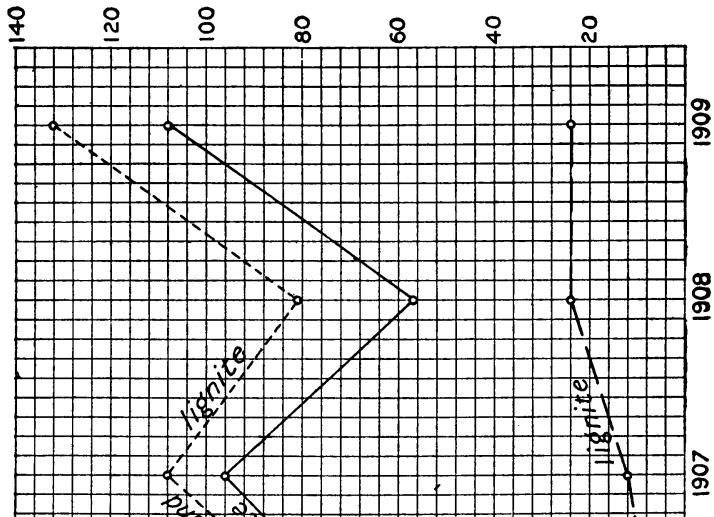

응

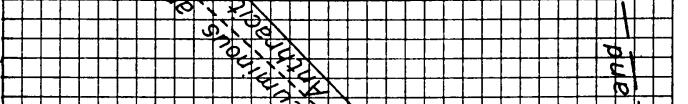

$\Phi$

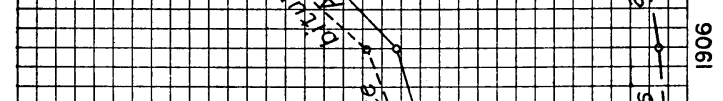

:

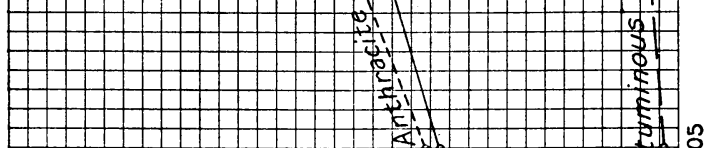

n

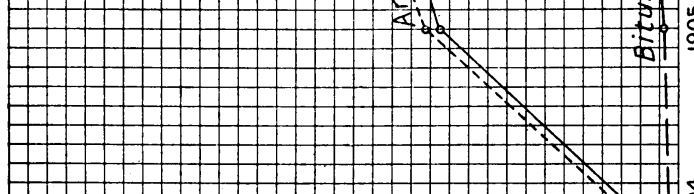

@
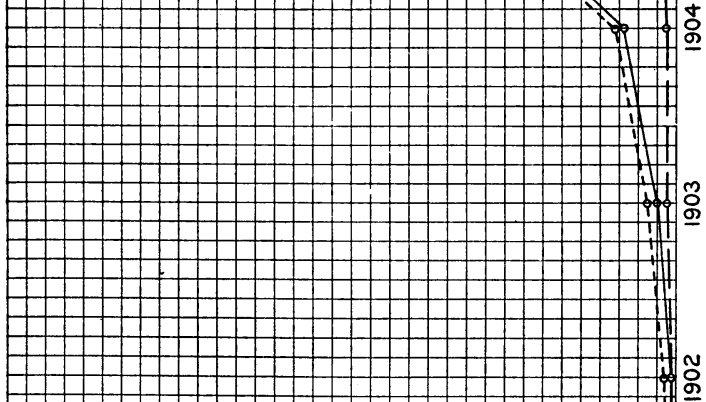

(1)

으 造
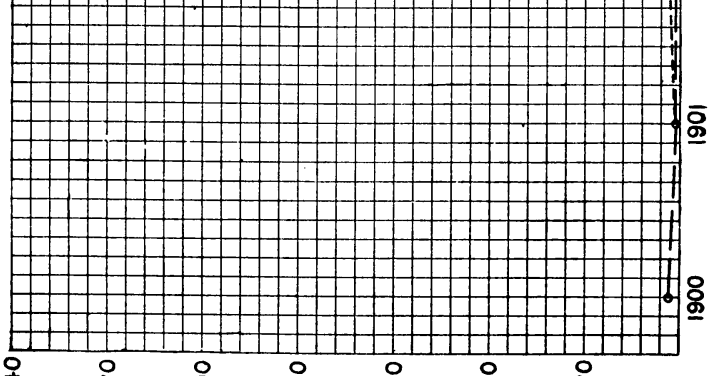

$\overline{\mathbf{g}}$

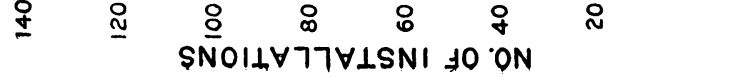


NUMBER AND DISTRIBUTION.

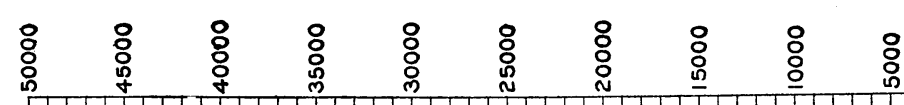

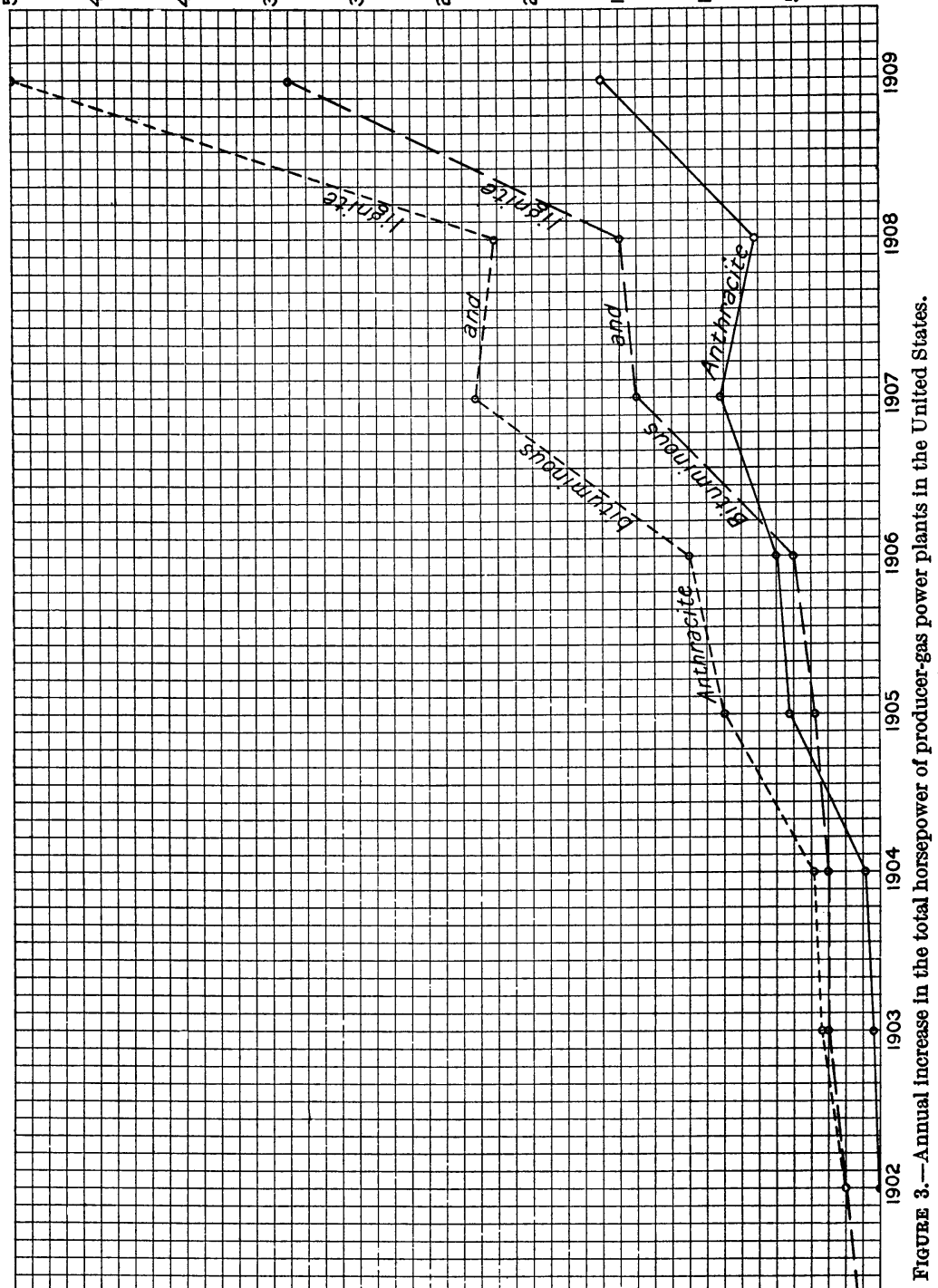

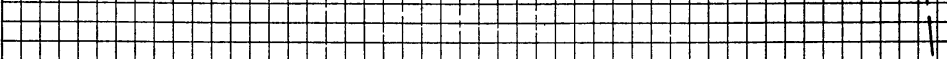

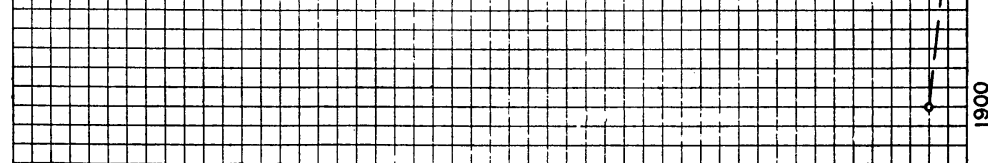

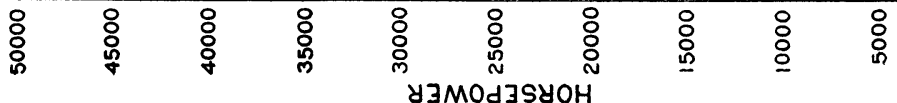


The following supplied the material from which the list is compiled. The abbreviations by which these makers are indicated in the list of plants are given in parentheses:

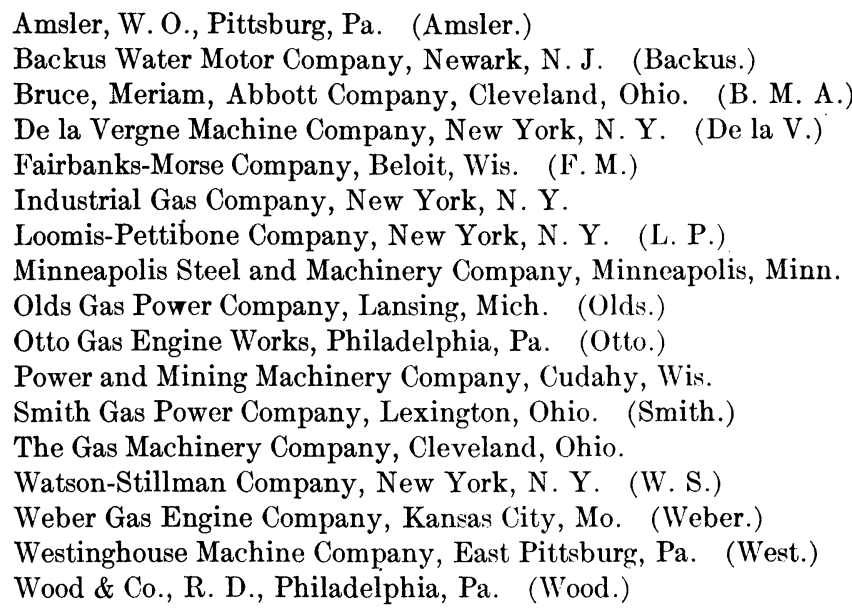

It is not claimed that the list presented is a complete record of all the installations made by these companies. Certain restrictions have been imposed in making up this list, some of which should be mentioned to avoid misunderstanding or incorrect inferences:

1. Some owners of plants object to making known the fact that they have such installations. Care has been exercised to prevent the insertion of the names of any such plants.

2. Some manufacturers have required that the individual consent of the owners of plants be secured before record of their existence could be made. As it was impossible to secure replies to many requests of this character, in the time at command, the original list supplied by the manufacturer has, in some cases, been materially reduced.

3. In certain instances the manufacturers have stated that their records are not sufficiently exact to enable them to make up complete lists.

4. One company does not approve of the presentation of a list of a great number of plants, and has restricted its own list to plants that have given unusual results, to those that are working in an unusual way or under extreme difficulties, and to those that show unusual economies or exceptional reliability.

One of the most interesting and surprising facts derived from an inspection of this list is the very general distribution of producer-gas power throughout the country. It is also noteworthy that the application of the anthracite producer is not limited to the East.

In order to emphasize this geographical distribution, the two accompanying maps (Pls. I and II) have been prepared. Plate I is based on the number of plants in each locality and Plate II on the relative capacity, expressed as horsepower, of the plants in the various States. 
NUMBER AND DISTRIBUTION.

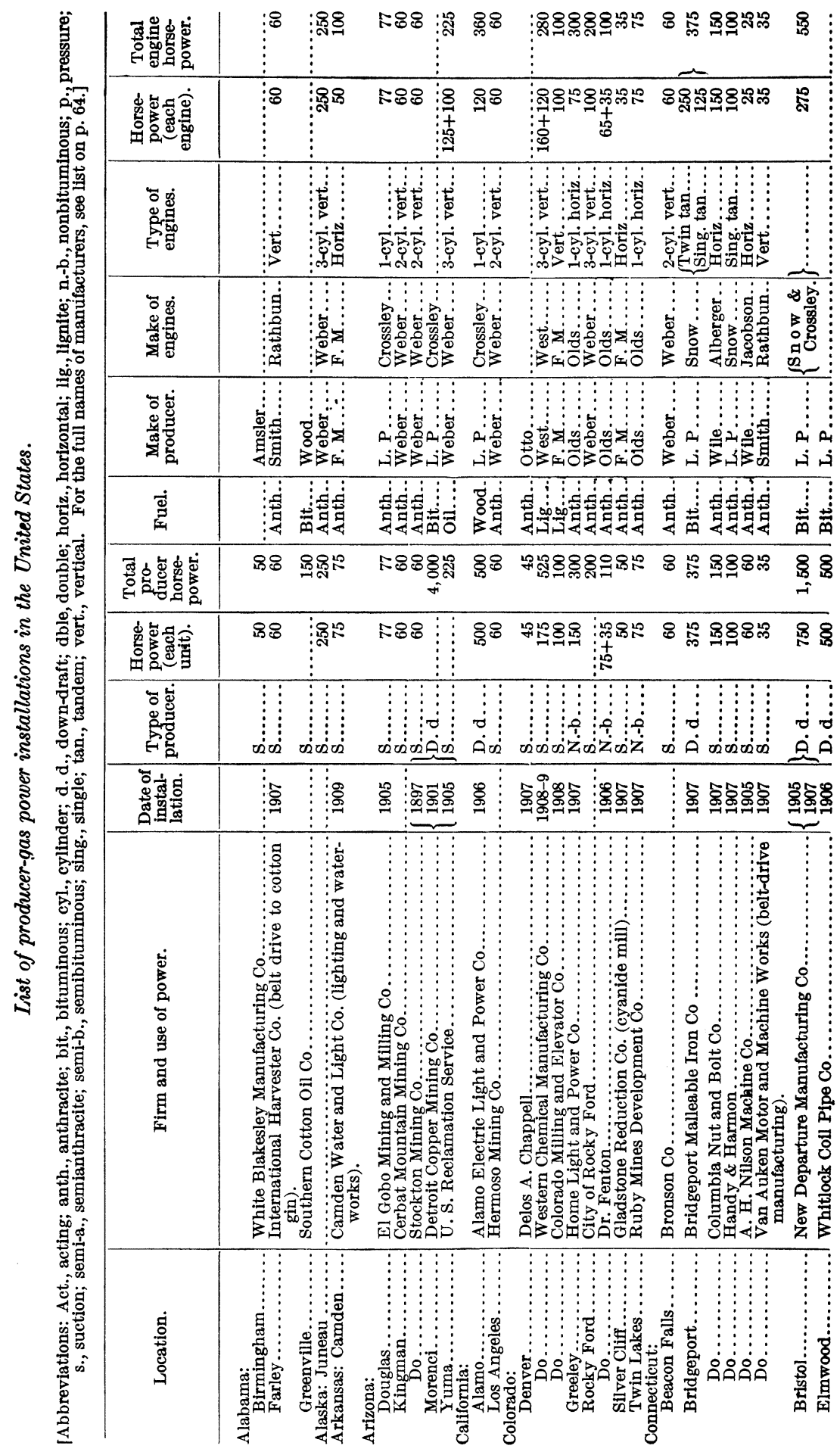

$68942^{\circ}-$ Bull. $9-10 \longrightarrow 5$ 


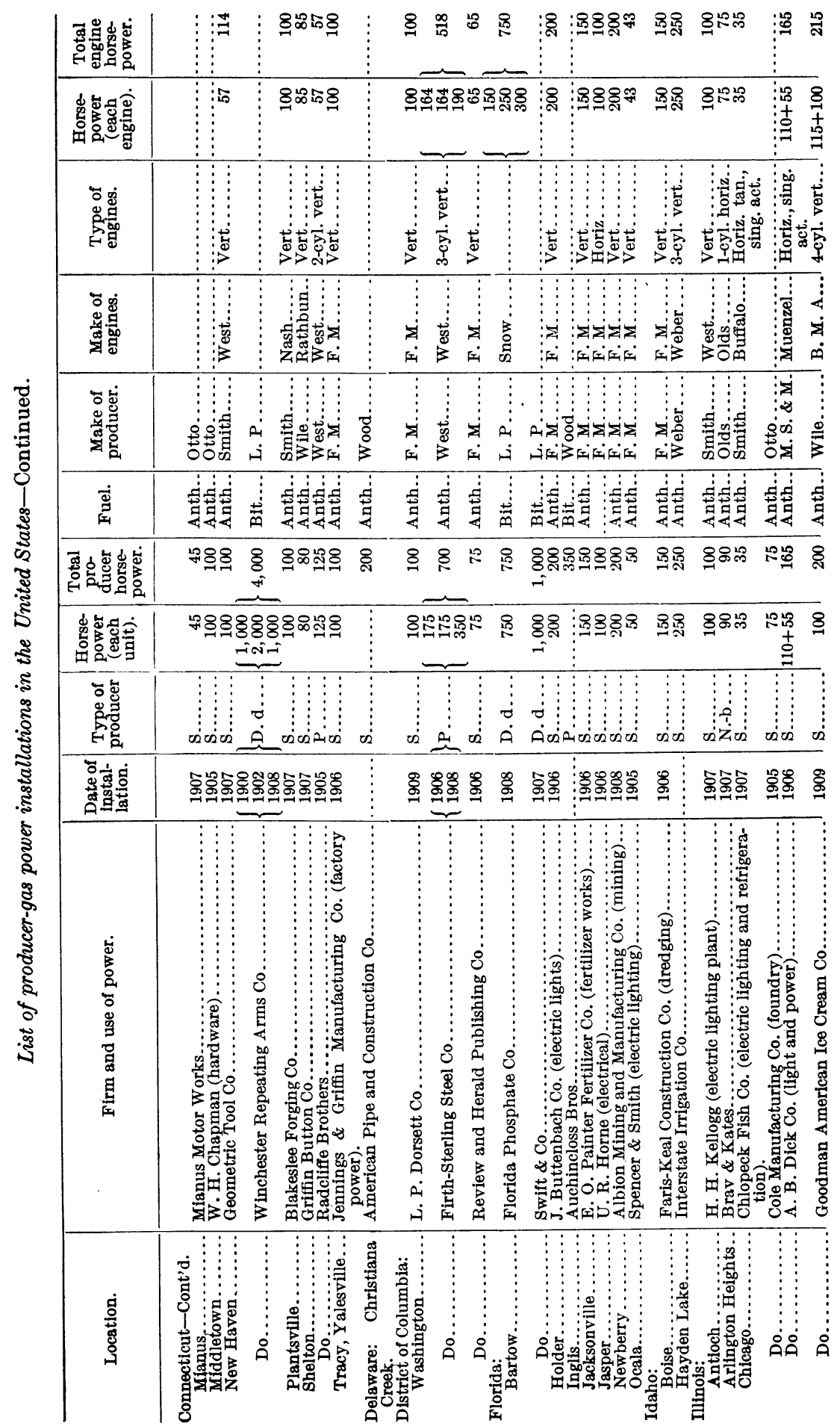




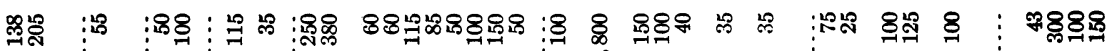

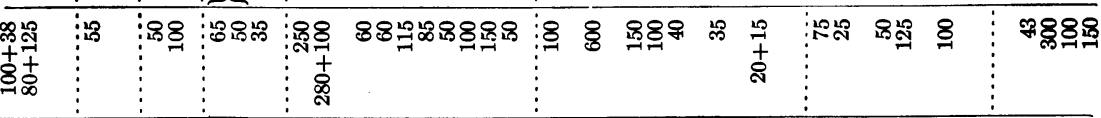
很是

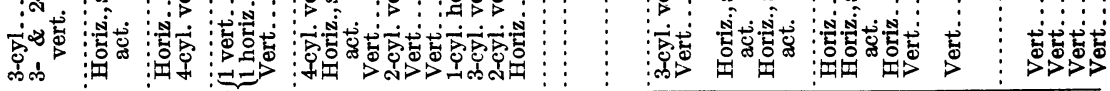

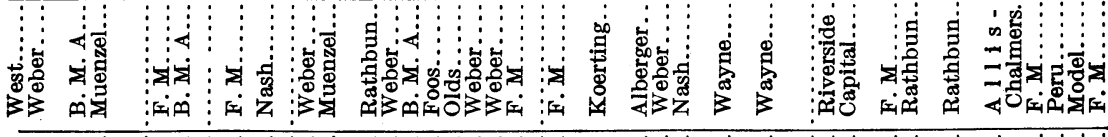

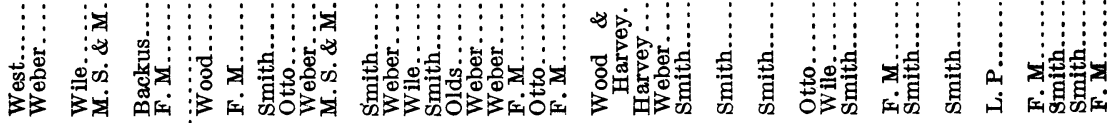

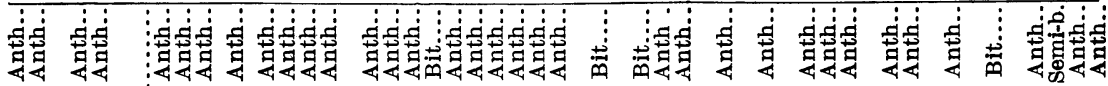

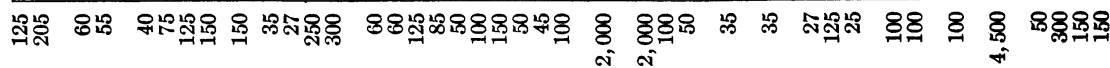
연

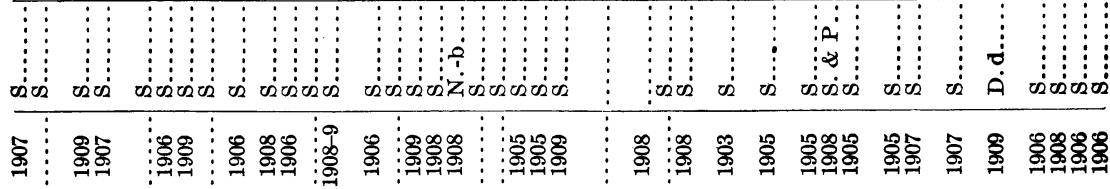

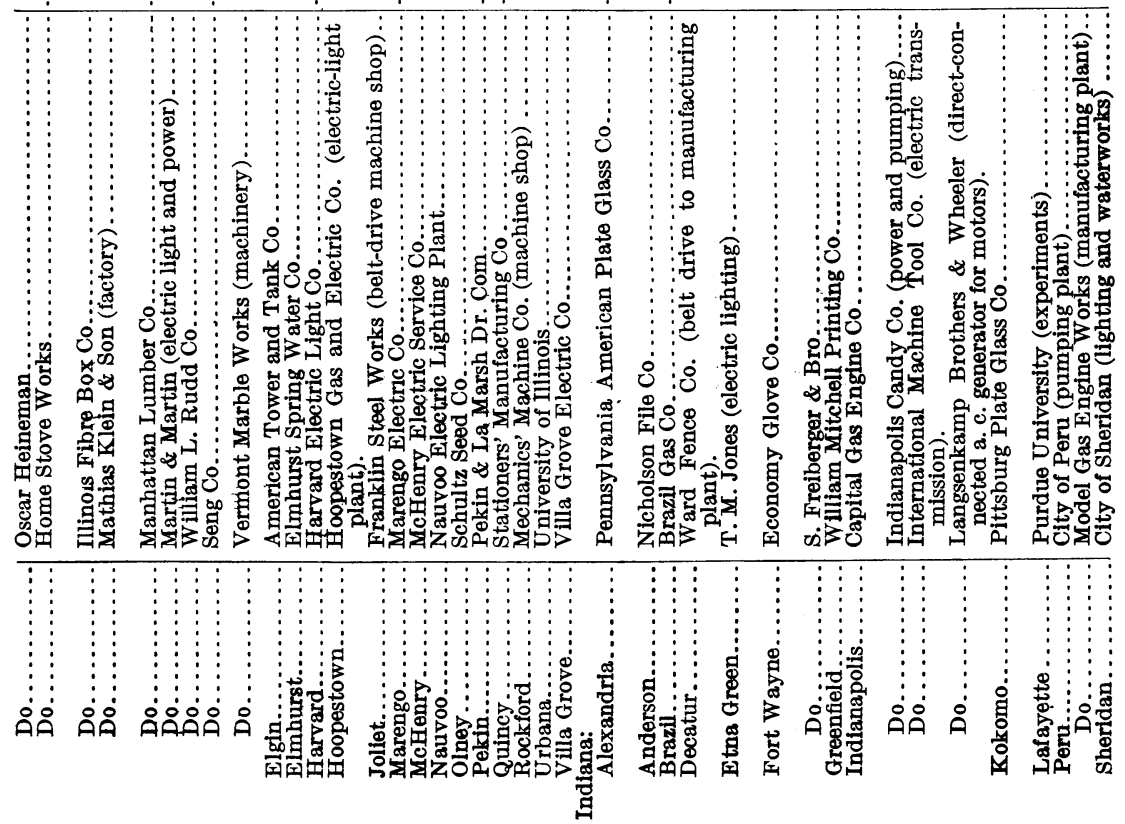




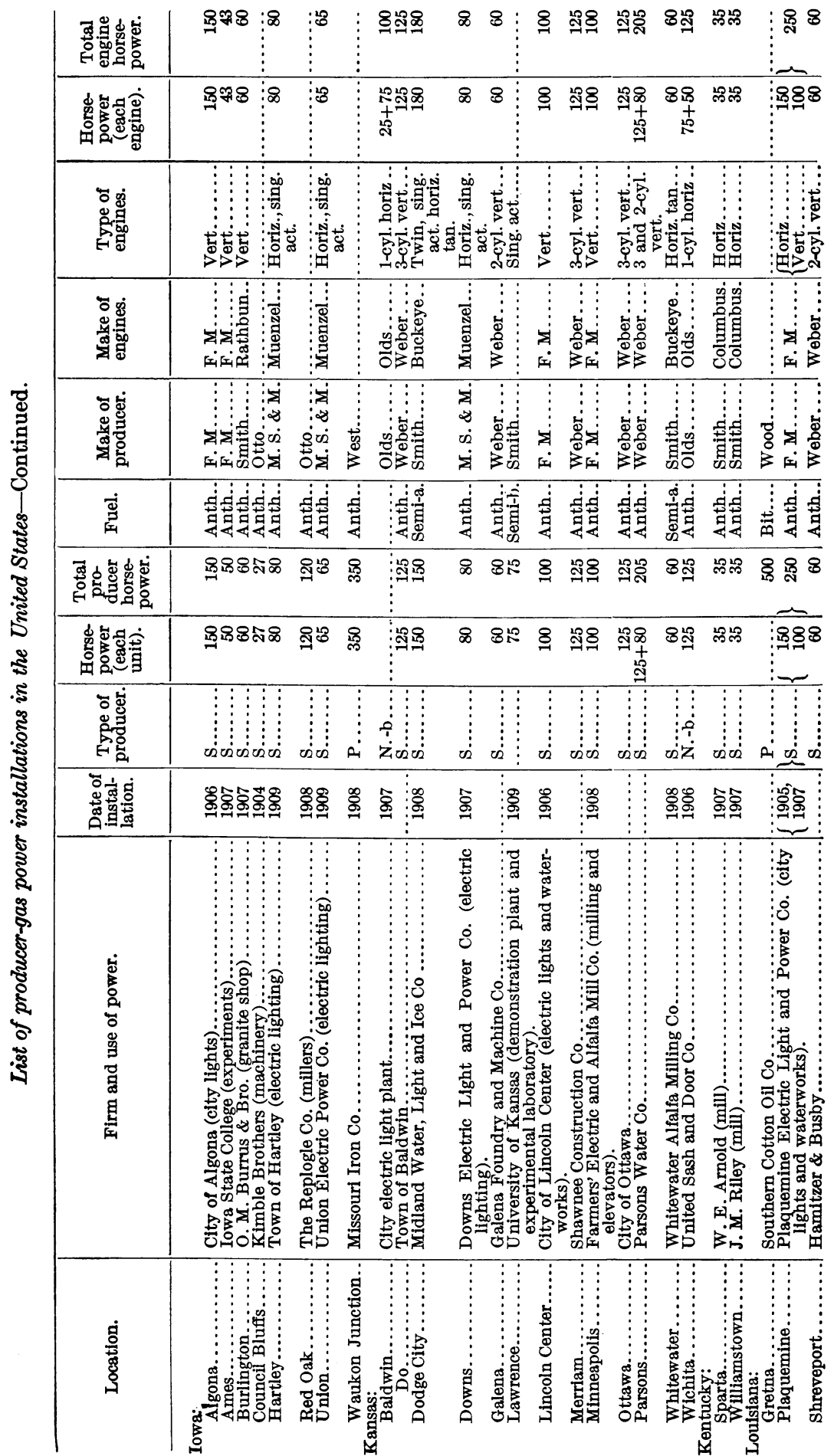




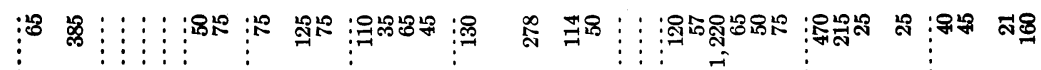

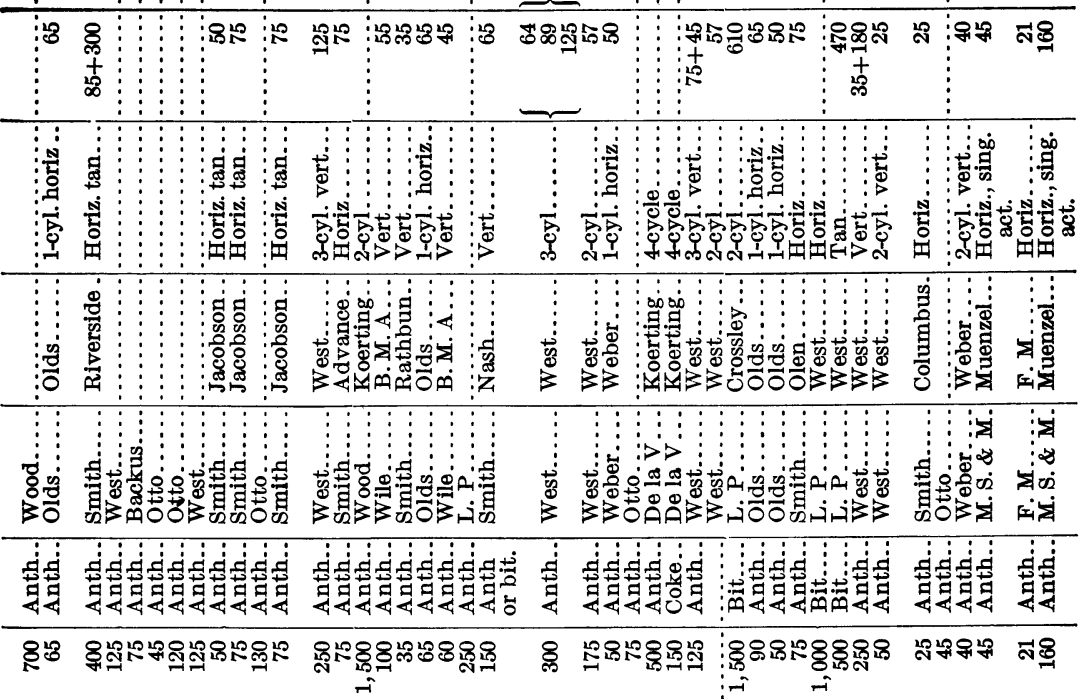

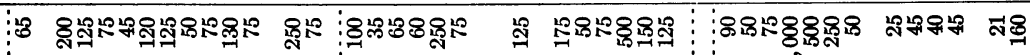

:

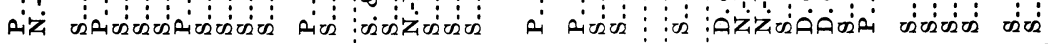

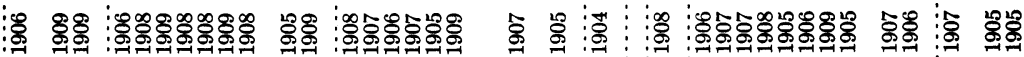

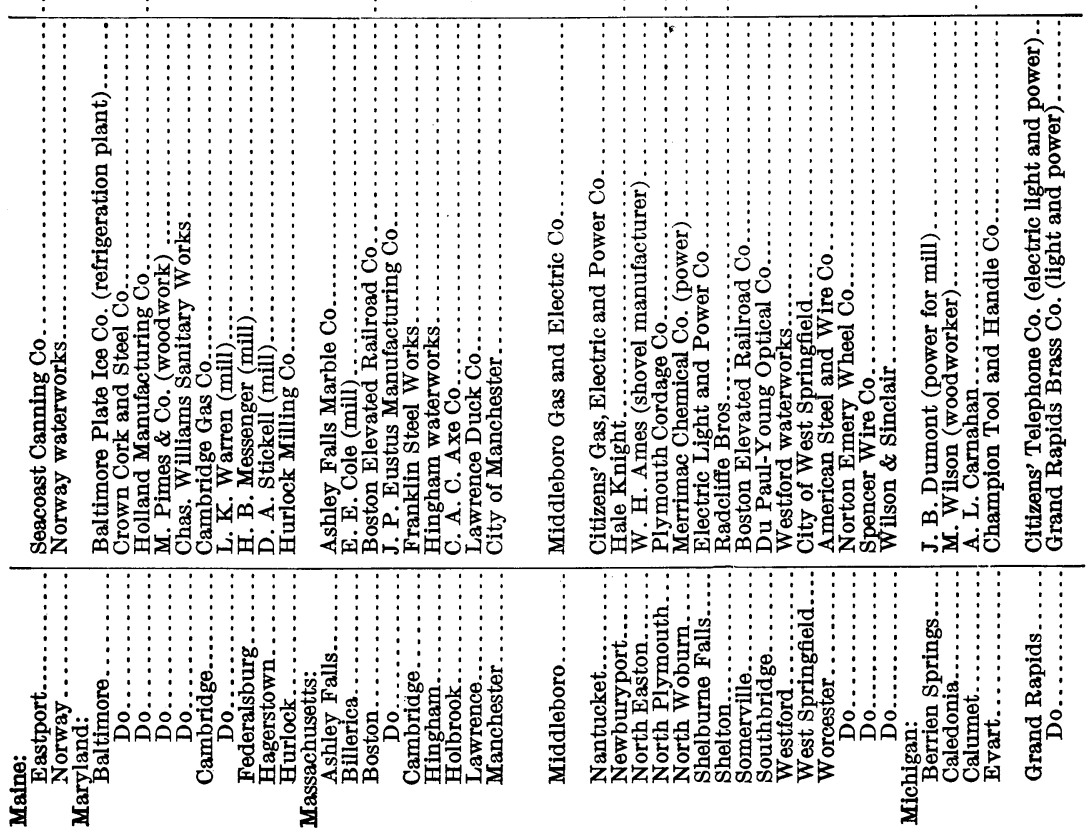




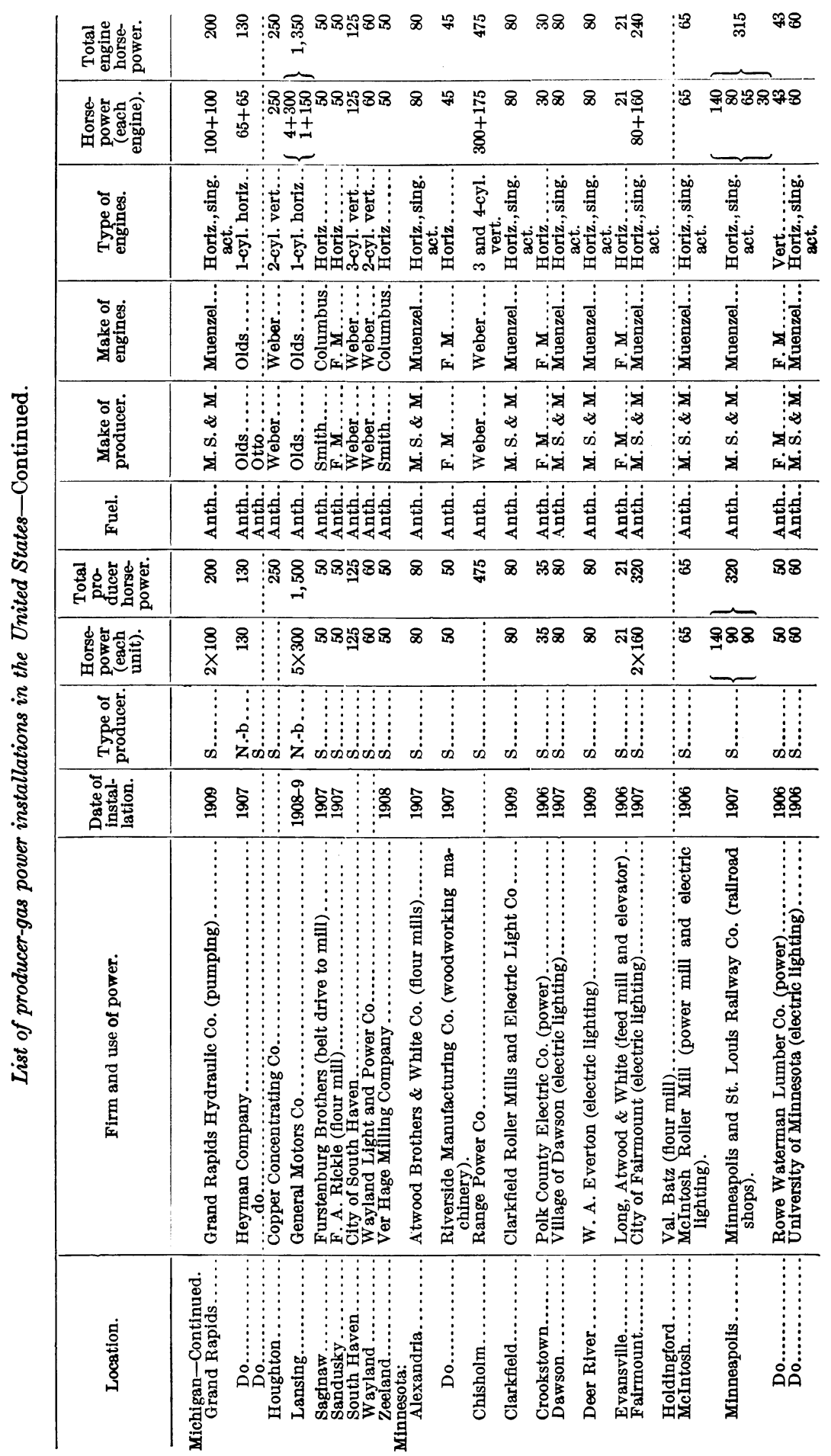




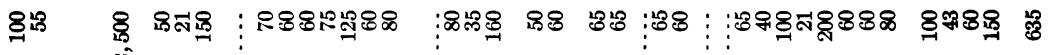

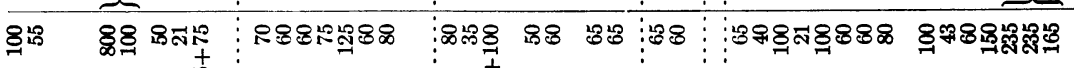
莴

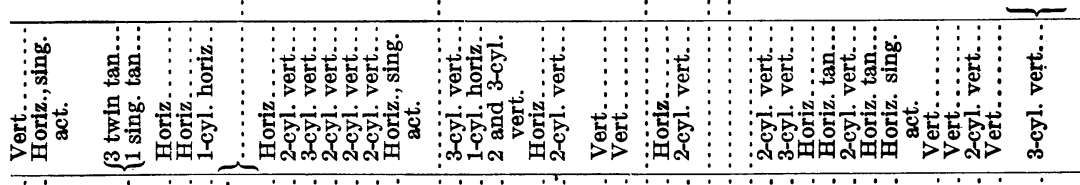

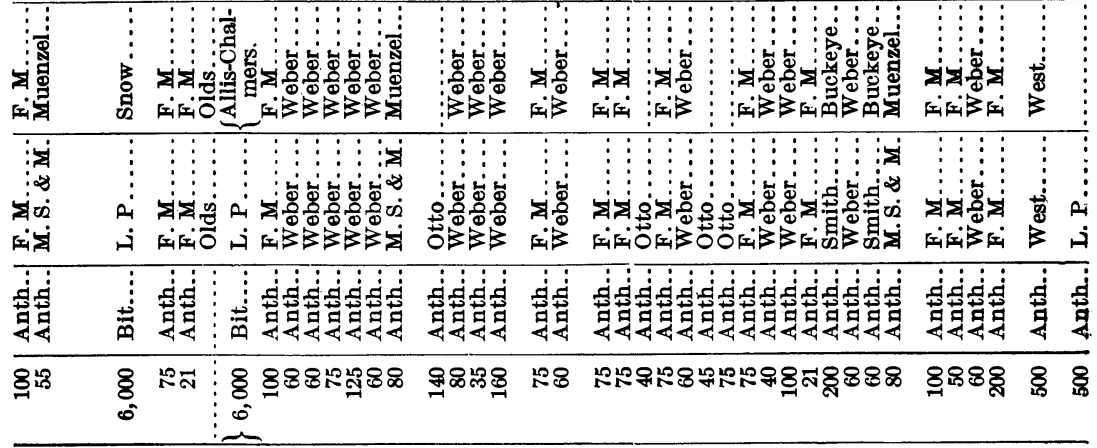

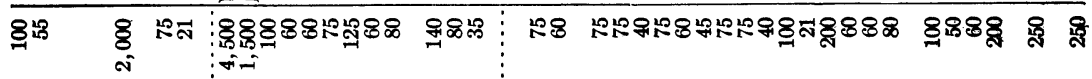

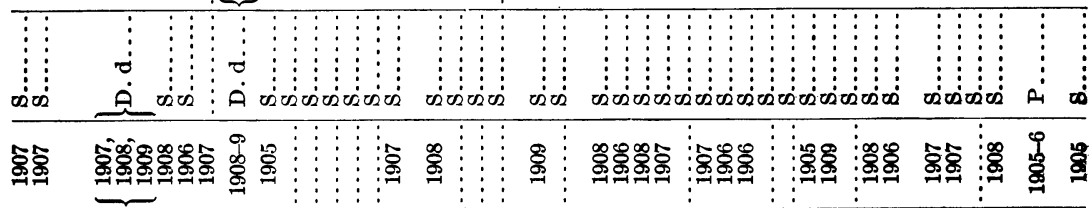

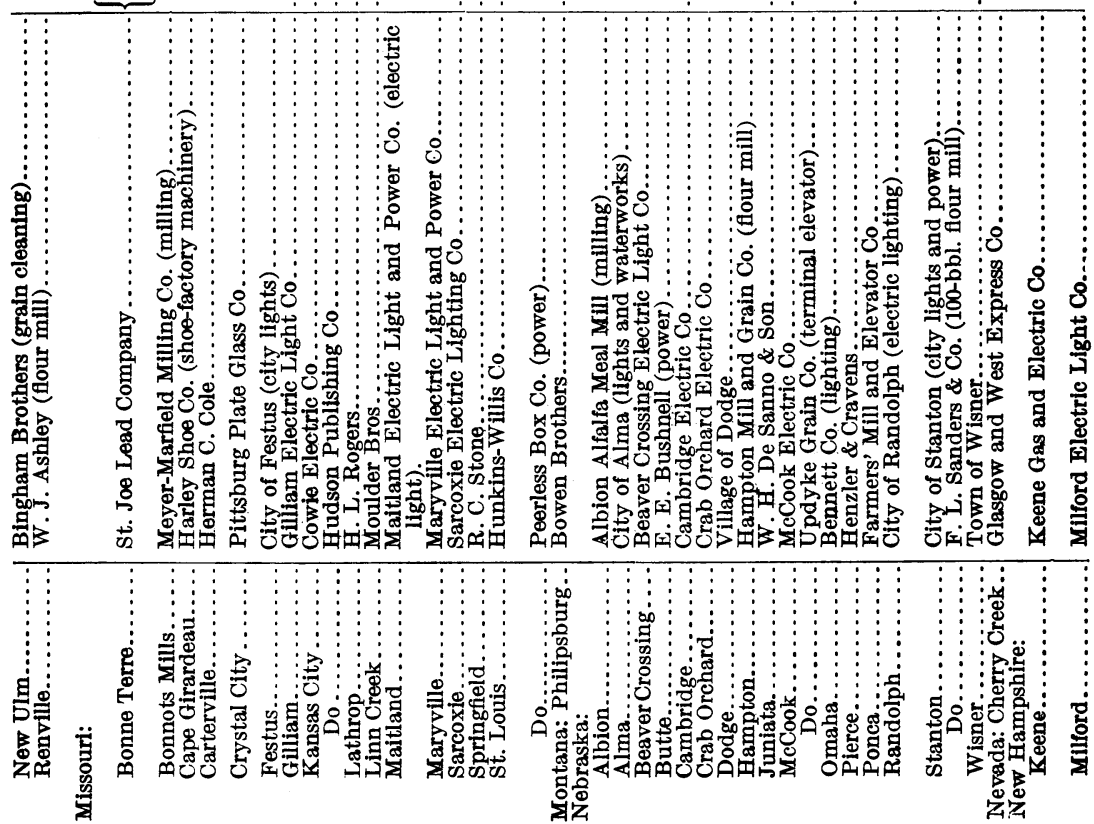


RECENT DEVELOPMENT OF PRODUCER-GAS POWER PLANT.

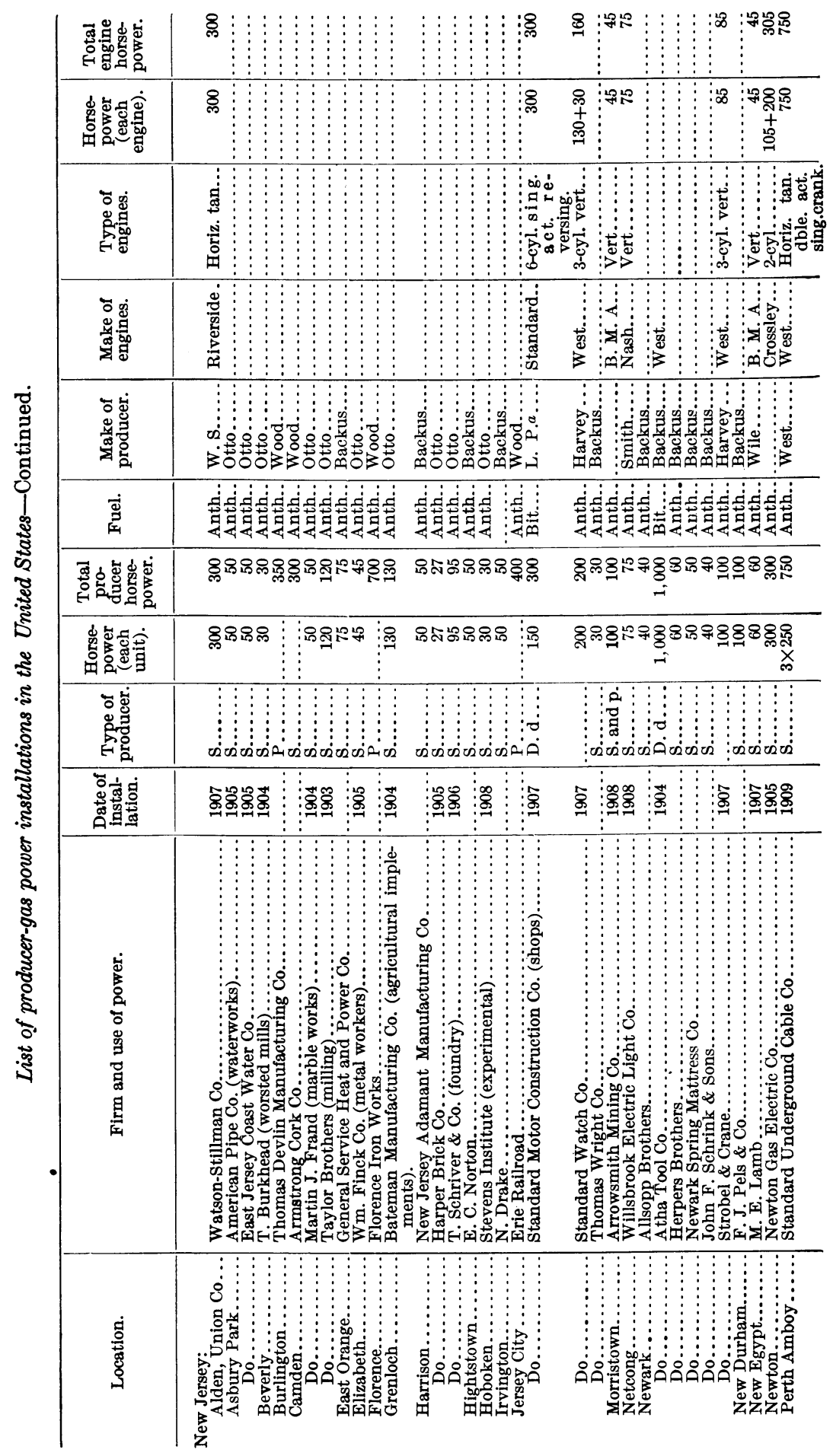




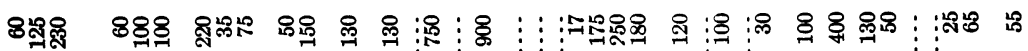

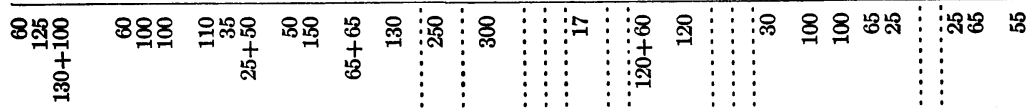

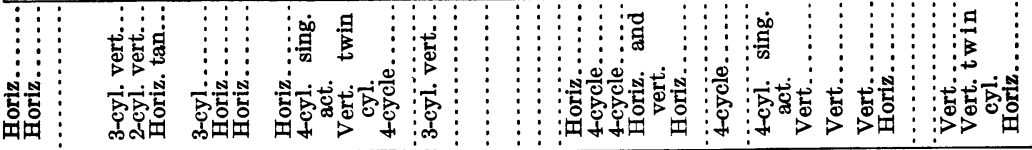

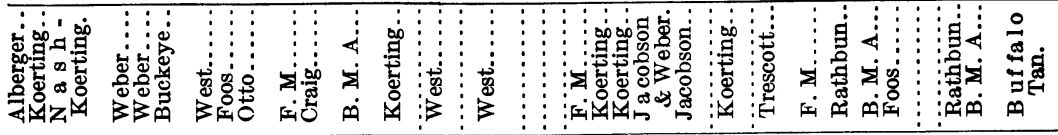

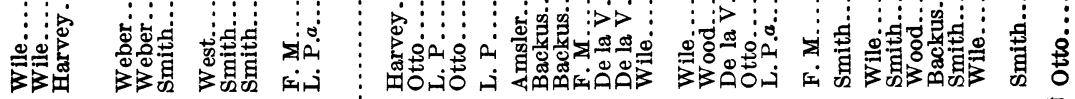

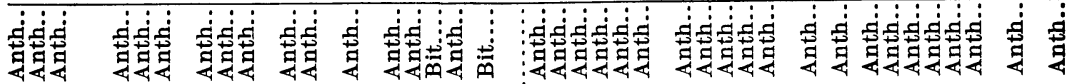

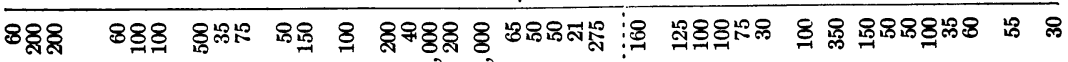

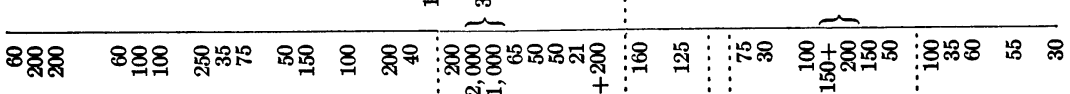

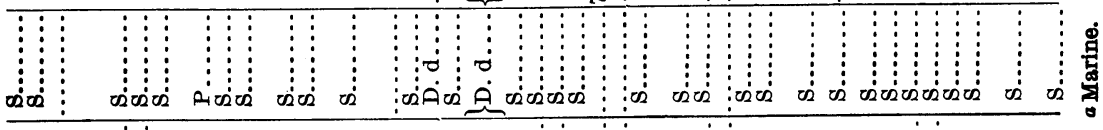

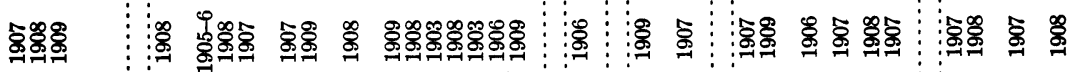

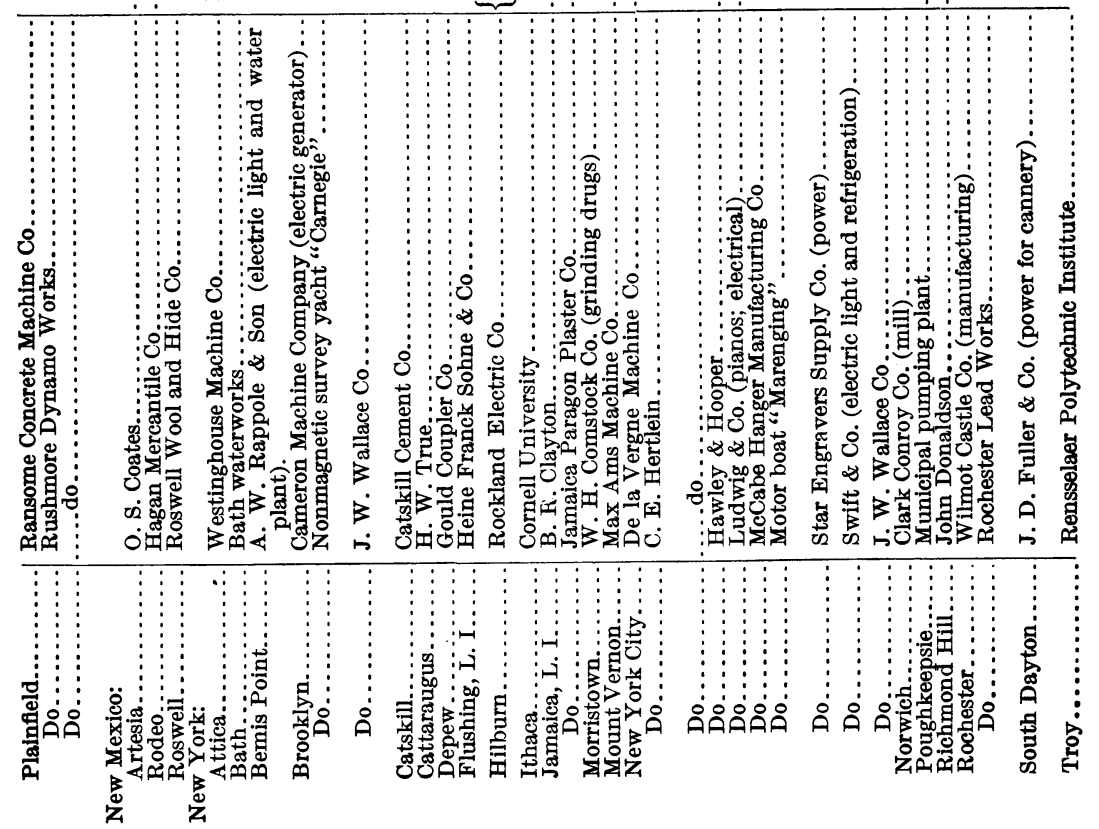




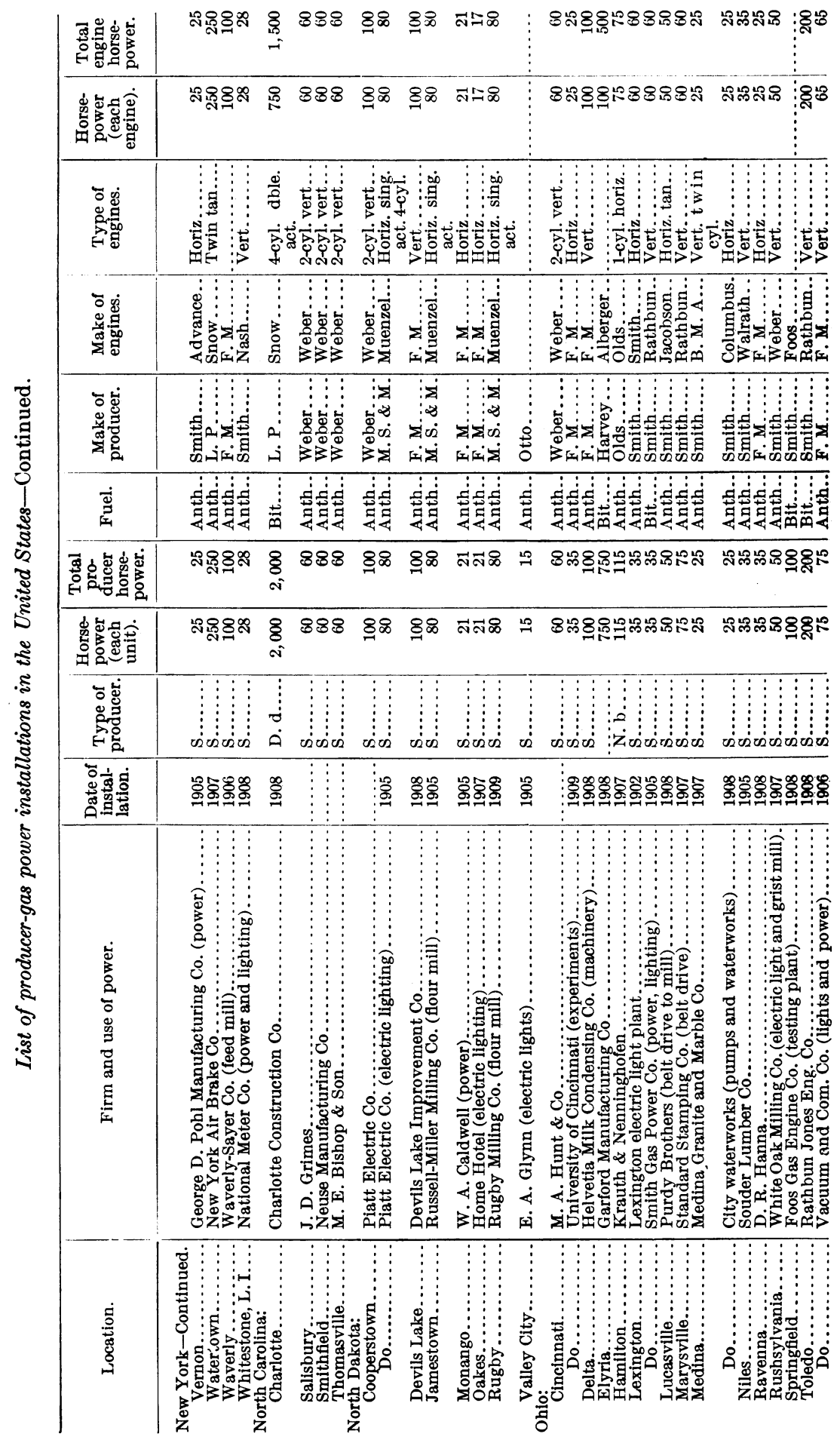




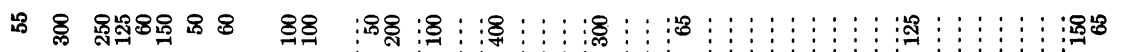

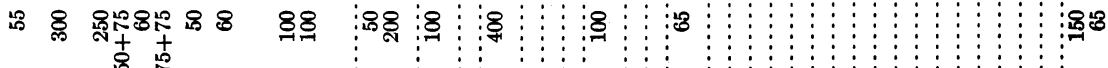

\begin{tabular}{|c|c|c|c|c|c|c|c|}
\hline 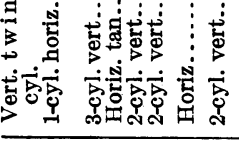 & 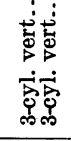 & 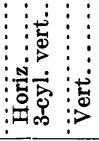 & 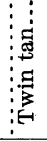 & 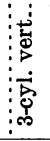 & $\begin{array}{l}\text { 范 } \\
\vdots\end{array}$ & 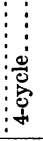 & \\
\hline 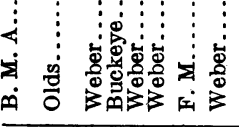 & 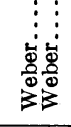 & 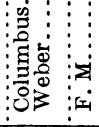 & 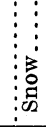 & 恶 & نג & 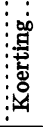 & \\
\hline
\end{tabular}

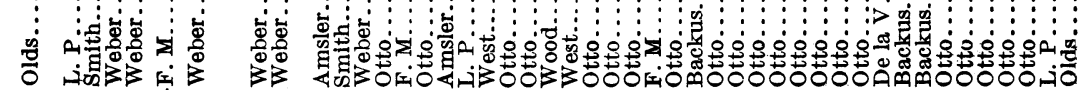

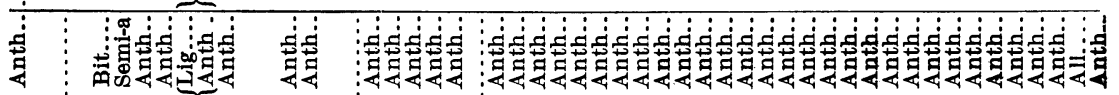

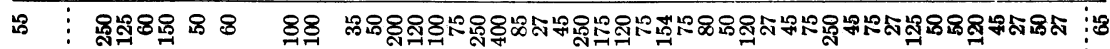

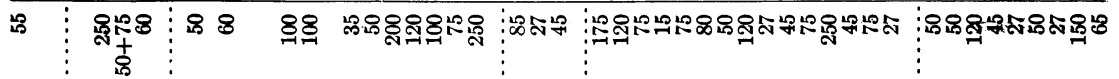

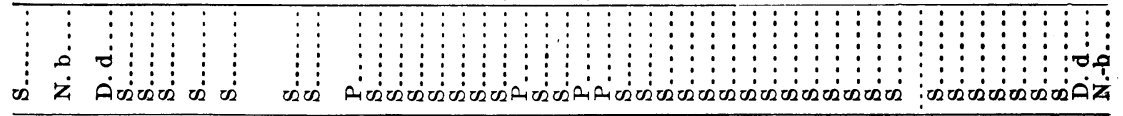

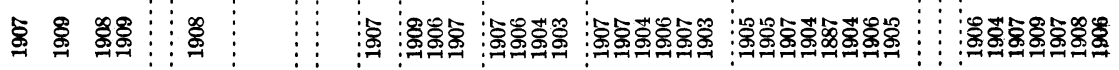

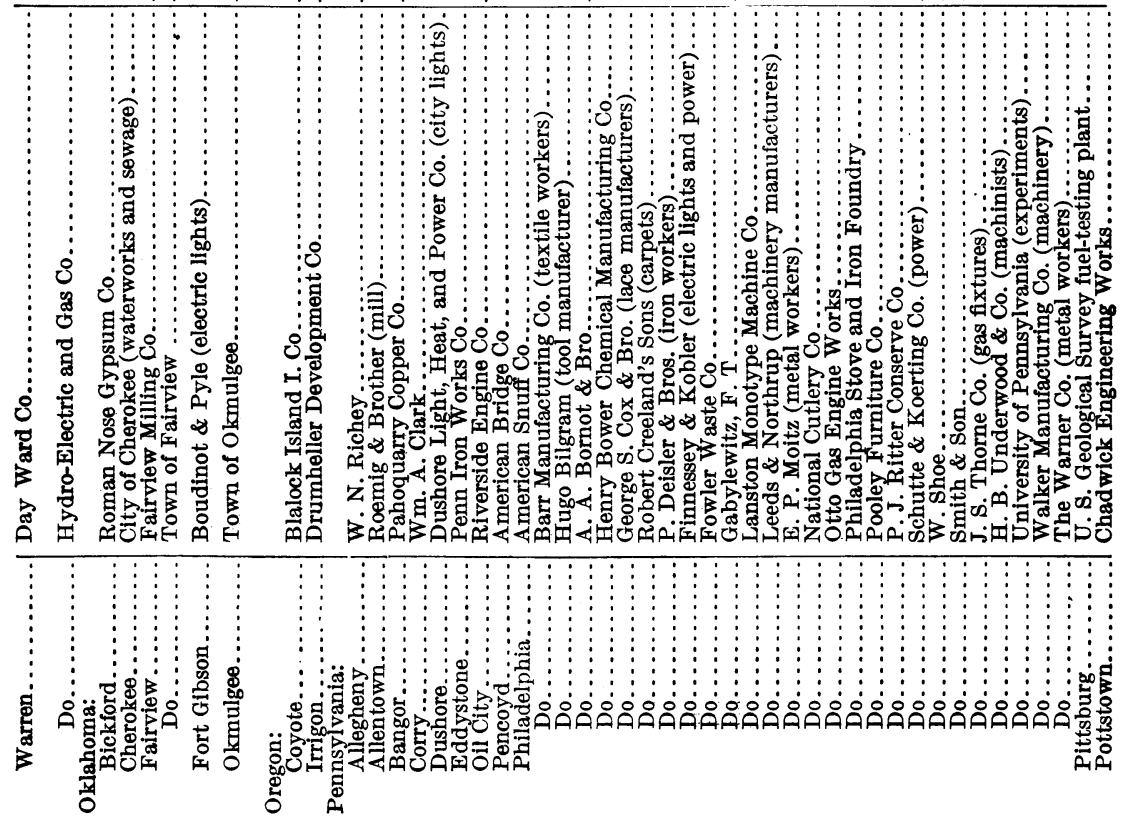




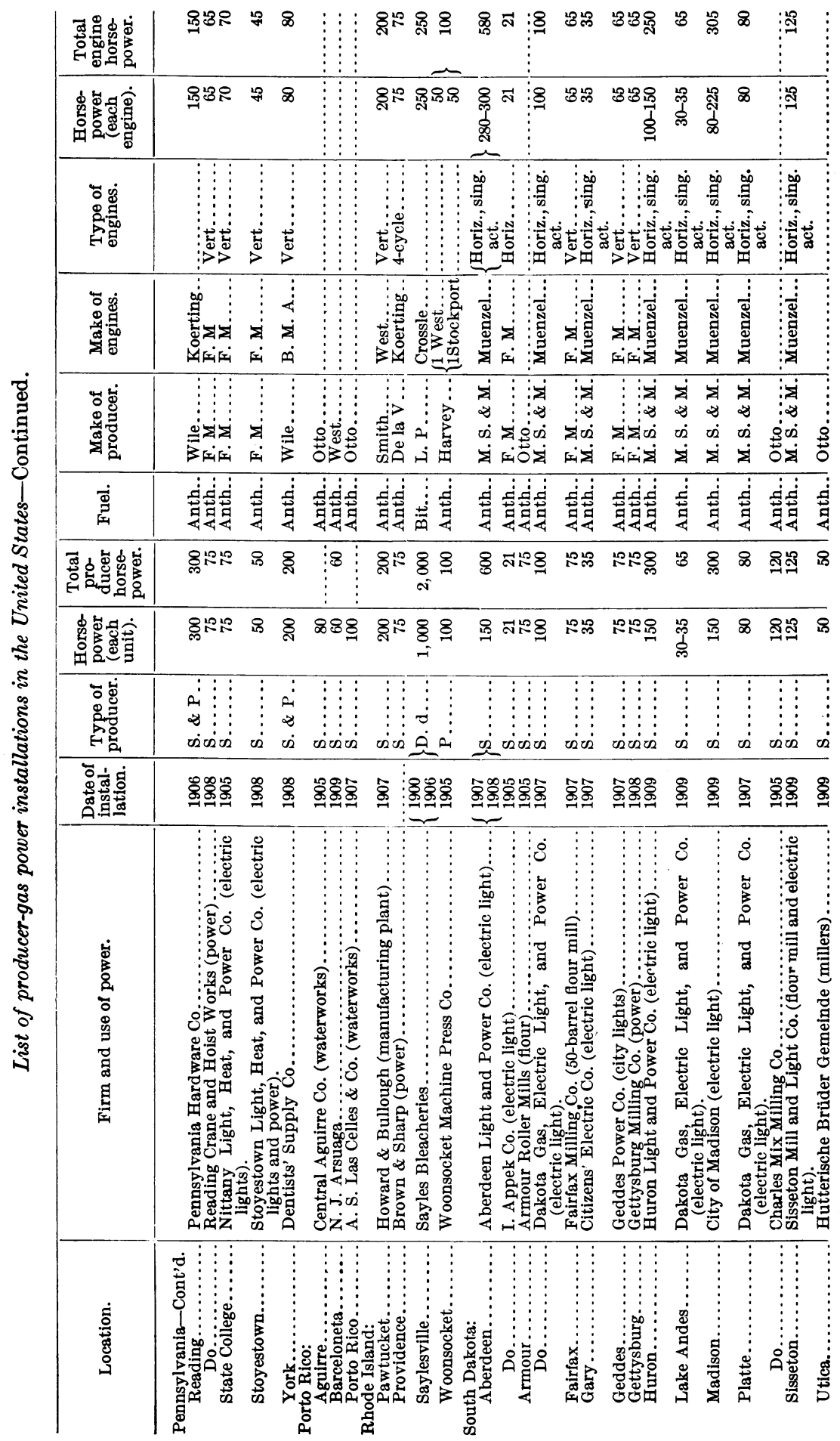




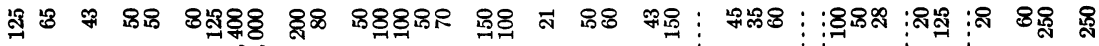
\$ భ

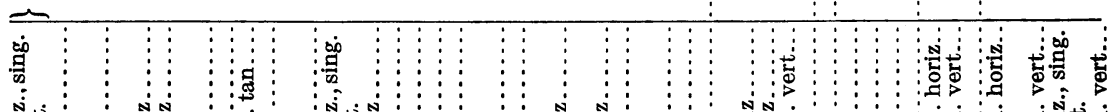

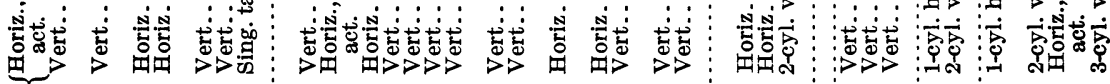

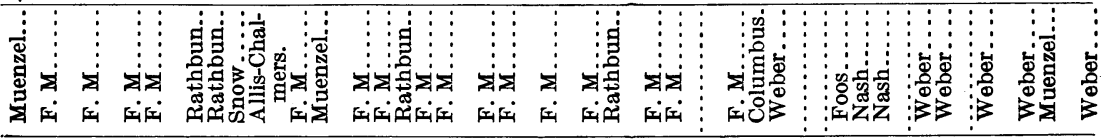

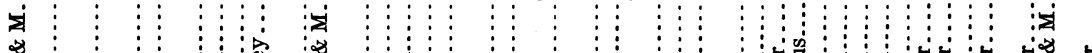

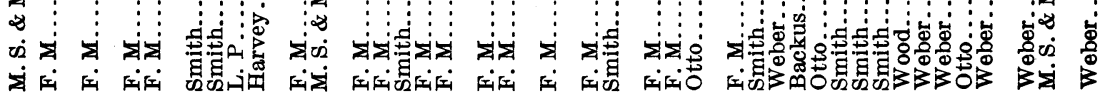

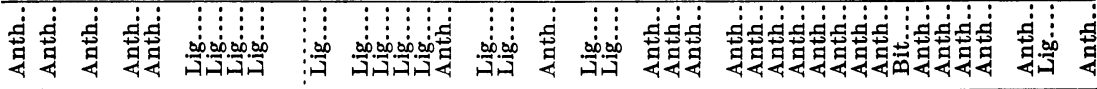

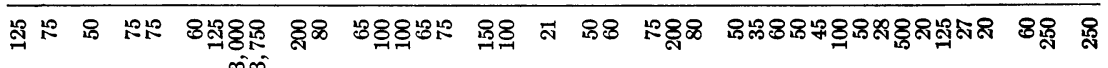
ติ

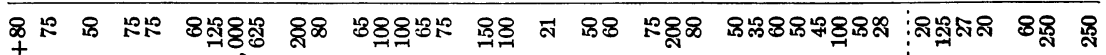
察

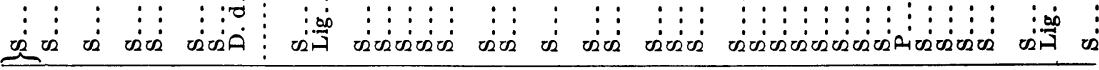

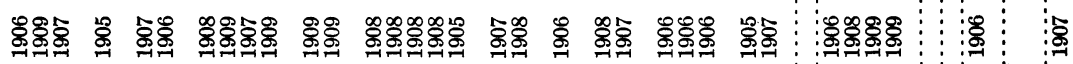

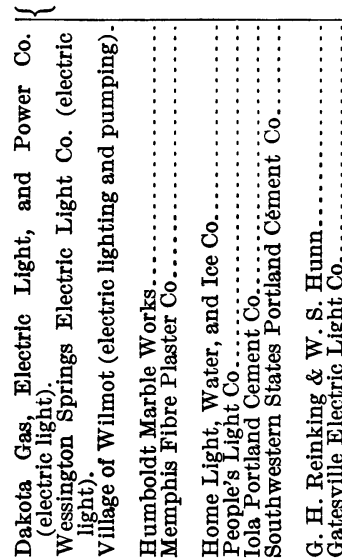

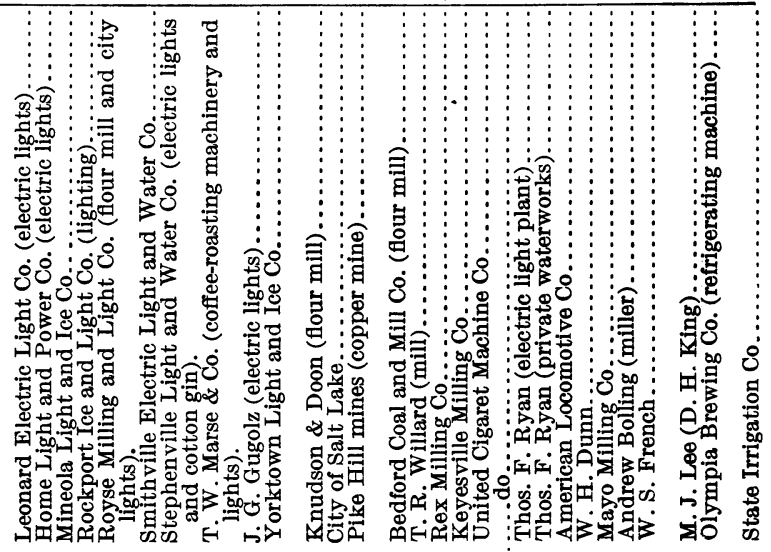

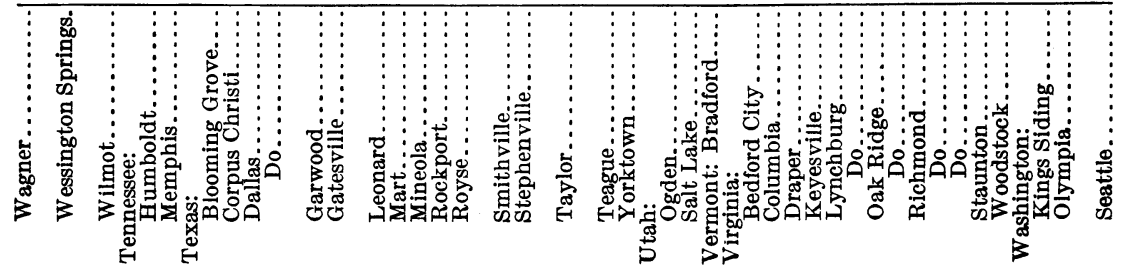




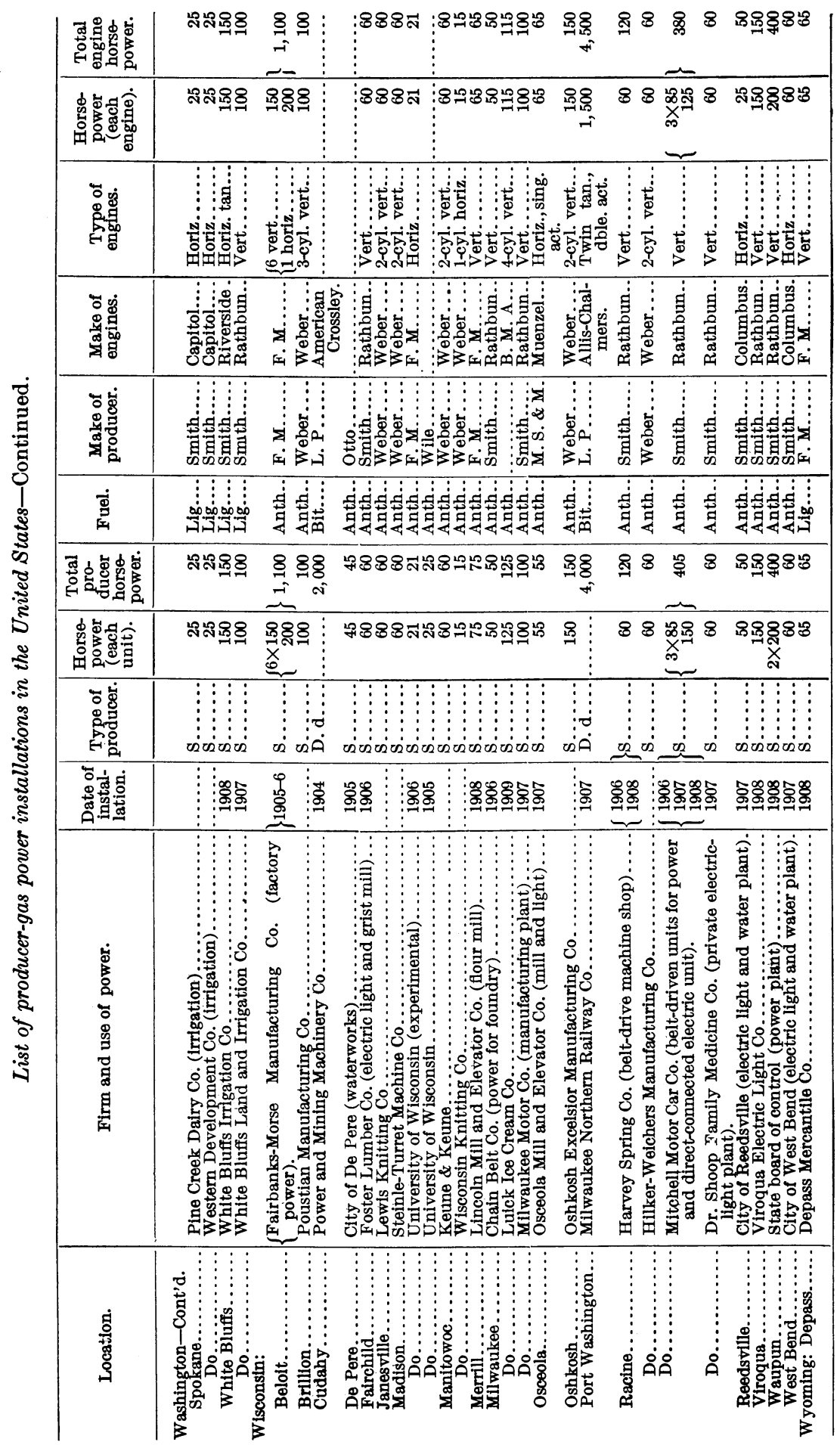




\section{CENTRALIZATION OF POWER DEVELOPMENT AND DIS- TRIBUTION.}

\section{INCREASE IN NUMBER OF CENTRAL STATIONS.}

Central stations for power and lighting are springing up all over the country. Electric lights are now in general use in towns numbering their population by hundreds only. Electric transmission for streetrailway service is practically universal and electric power for shop drive is in great demand. The substitution of the electric locomotive for the steam locomotive for terminal service and even for line duty by several leading railway systems is no longer a mere expectation, but is an every-day working reality.

These changes and developments in every section are, to a large extent, tending to do away with the individual small steam equipment, whether stationary or locomotive, and are bringing to the front the central power station, ranging in size from lighting and pumping plants of less than 100 horsepower in the smaller towns to those of 100,000 horsepower or more required to meet metropolitan demands.

\section{EUROPEAN EXAMPLES OF ADVANTAGEOUS LOCATION.}

In the development of central power plants and the reduction of the cost of power, the producer-gas power plant is an important factor. In this connection the question of locating such plants directly at the mines is well worth careful and unbiased attention in the engineering profession. The advantages to be derived from such a location have already attracted the commercial interests of Europe. As examples worthy of thoughtful consideration, the general conditions of operation of three typical European installations are here described:

Plant A.-This plant, although not situated directly at the mines, is but a short distance away, and the company owning the plant also owns the mines from which the fuel is secured. The plant is of the Mond by-product type and consists of eight pressure producers of 2,500 horsepower each. The fuel used is a run-of-mine bituminous coal said to contain 8 to 9 per cent ash and 1 to 2 per cent sulphur. This would indicate that they are utilizing the best grades of coal from their own mine in the local gas plant and allowing the lower grades to remain unmined, a fact which I verified before leaving the plant.

The plant is designed for the recovery of the sulphate of ammonia and for supplying gas to the neighboring towns for both metallurgical and power purposes. As one unit is always held in reserve, the plant is called 16,000 horsepower. The main distributing line is 3 feet in diameter, and at the time of my visit there were 37 miles of main, the longest single run being $6 \frac{1}{2}$ miles. Each producer gasifies, on an 
average, 20 tons of coal per twenty-four hours. The report of the engineer in charge indicates that the plant had been in operation twenty-four hours a day, seven days a week, for two and one-half years without a shut-down.

Plant B.-This plant, which is located in the center of a peat bog, proved of especial interest. It has a capacity of 300 horsepower only, and is about 3 miles from the town to which the electric current is supplied. One-half of the plant (150 horsepower) was installed in 1904 and the remainder in 1906 . This is probably the first as well as the smallest producer-gas installation to be located at the mine and transmit high-voltage current to a point some distance away. This installation, in 1909, consisted of two suction producers (special peat type) rated at 150 horsepower each, and two horizontal twin singleacting four-cycle gas engines of 150 horsepower each, direct connected to alternating-current three-phase generators, which were running splendidly in parallel at the time of my visit. The 3,000-volt current is transmitted to the town, where it is used during the day for lighting shops and for shop motors. At night the plant supplies the lights for the streets and residences. The charge for residence lighting is 9 cents per kilowatt hour. Both units are in operation from 5.30 a. m. to 6 p. m., and one continues to 11 p. m. each day.

A 35-horsepower peat machine is used for preparing the fuel. This is driven by an electric motor supplied with current from the power plant on the bog. As only 750 tons of dry peat are required per year there is no attempt to work the plant to its maximum. Local farmers are employed and they work as little or as much as they please, as there is no difficulty in getting out all the peat needed for a year during the working season, which in this locality is from April 15 to September 1. As a result 14 men are employed more or less of their time. They receive about 50 cents per day each and get out about 20 tons of peat per day.

Coal at this point in Europe costs $\$ 3.75$ per ton. The dry peat delivered on the operating platform of the producer plant costs only 80 cents per ton.

Plant C.-This plant, which is installed at the collieries, is the one that was briefly described on page 30 (the last one mentioned under item 8).

\section{FAVORABLE CONDITIONS IN THE UNITED STATES.}

In the United States cheaper power is constantly sought. The water-power possibilities of the country are being realized and the hydro-electric power plant is a wholesome cause of competition. The supply of fuel of marketable grades is not unlimited. Prices for such fuel must of necessity increase. The cost of transporting coal from the mines is high, and the possibility of obtaining a sufficient supply of cars to handle low-grade fuels is questionable. The power 
demands of the country are increasing, and this power must be developed at a reasonable cost. The time is. approaching when the cheapest fuel obtainable must be used to the best economic advantage in order to develop power at a unit cost consistent with commercial progress.

Consideration of the conditions indicates that in order to keep the price of power developed from fuel down to a consistent figure-

(a) Grades of fuel which warrant transportation, or which may be defined as "marketable," should be used with the greatest practicable economy.

(b) The very large percentage of coal of so-called low grade which to-day is left at or in the mine must be utilized.

(c) Advantage must be taken of the large deposits of lignite and peat which are found in many sections of the country.

It is undoubtedly true that in general, under conditions which do not require the use of steam for other than power purposes, the producer-gas power plant meets the requirements of $(a)$.

At present the only method of advantageously handling the fuels mentioned in $(b)$ and $(c)$ is in the gas producer, and the utilization of these lower grades of fiel on an extensive scale demands concentration of the power planis within close proximity to the fuel supply.

The logical conclusion from a careful study of the producer-gas power situation is that the time is not distant when financial interests in power production will be directed toward the centralization of the producer-gas power plant at the mines and the distribution of the energy developed either by high-voltuge long-distance electrical transmission or by pipe systems for conveying the gas.

\section{PUBLICATIONS ON FUEL TESTING.}

The following publications, except those to which a price is affixed, can be obtained free by applying to the Director, Bureau of Mines, Washington, D. C. The priced publications can be purchased from the Superintendent of Documents, Government Printing Office, Washington, D. C.

Bulletin 261. Preliminary report on the operations of the coal-testing plant of the United States Geological Survey at the Louisiana Purchase Exposition, in St.

Louis, Mo., 1904; E. W. Parker, J. A. Holmes, M. R. Campbell, committee in charge. $1905.172 \mathrm{pp} .10$ cents.

Professional Paper 48. Report on the operations of the coal-testing plant of the United States Geological Survey at the Louisiana Purchase Exposition, St. Louis, Mo., 1904; E. W. Parker, J. A. Holmes, M. R. Campbell, committee in charge. 1906. In three parts. $1492 \mathrm{pp} . \$ 1.50$.

Bulletin 290. Preliminary report on the operations of the fuel-testing plant of the United States Geological Survey at St. Louis, Mo., 1905, by J. A. Holmes. 1906. 240 pp. 20 cents.

$68942^{\circ}-$ Bull. $9-10-6$ 
Bulletin 323. Experimental work conducted in the chemical laboratory of the United States fuel-testing plant at St. Louis, Mo., January 1, 1905, to July 31, 1906, by N. W. Lord. 1907. 49 pp. 10 cents.

Bulletin 325. A study of four hundred steaming tests, made at the fuel-testing plant, St. Louis, Mo., 1904-1906, by L. P. Breckenridge. 1907. 196 pp. 10 cents.

Bulletin 332. Report of the United States fuel-testing plant at St. Louis, Mo., January 1, 1906, to June 30, 1907; J. A. Holmes, in charge. 1908.299 pp.

BULLETIN 334. The burning of coal without smoke in boiler plants; a preliminary report, by D. T. Randall. 1908. 26 pp. 5 cents. (See Bulletin 373.)

Bulletin 336. Washing and coking tests of coal and cupola tests of coke, by Richard Moldenke, A. W. Belden, and G. R. Delamater. 1908. 76 pp. 10 cents.

Bulletin 339. The purchase of coal under government and commercial specifications on the basis of its heating value, with analyses of coal delivered under government contracts, by D. T. Randall. 1908 . 127 pp. 5 cents. (See Bulletin 378.)

Bulletin 343. Binders for coal briquets, by J. E. Mills. 1908. 56 pp.

Bulletin 362. Mine sampling and chemical analyses of coals tested at the United States fuel-testing plant, Norfolk, Va., in 1907, by J. S. Burrows. 1908. 23 pp. 5 cents.

Bulletin 363. Comparative tests of run-of-mine and briquetted coal on locomotives, including torpedo-boat tests and some foreign specifications for briquetted fuel, by W. F. M. Goss. 1908. 57 pp.

Bulletin 366. Tests of coal and briquets as fuel for house-heating boilers, by D. T. Randall. 1908. $44 \mathrm{pp}$.

Bulletin 367. Significance of drafts in steam-boiler practice, by W. T. Ray and Henry Kreisinger. 1909. $61 \mathrm{pp.}$

Bulletin 368. Washing and coking tests of coal at Denver, Colo., by A. W. Belden, G. R. Delamater, and J. W. Groves. 1909. 54 pp.

Bulletin 373. The smokeless combustion of coal in boiler plants, by D. T. Randall and H. W. Weeks. 1909. $188 \mathrm{pp.}$

Bulletin 378. Results of purchasing coal under government speçifications, by J. S. Burrows; Burning the small sizes of anthracite for heat and power purposes, by D. T. Randall. 1909. $44 \mathrm{pp}$.

Bulletrin 385. Briquetting tests at Norfolk, Va., by C. L. Wright. $1909.41 \mathrm{pp}$.

Bulletin 392. Commercial deductions from comparisons of gasoline and alcohol tests on internal-combustion engines, by R. M. Strong. 1909 . $38 \mathrm{pp}$.

Bulletin 393. Incidental problems in gas-producer tests, by R. H. Fernald, C. D. Smith, J. K. Clement, and H. A. Grine. 1909. 29 pp.

Bulletin 402. The utilization of fuel in locomotive practice, by W. F. M. Goss. 1909. $28 \mathrm{pp}$.

Bulletin 403. Comparative tests of run-of-mine and briquetted coal on the torpedo boat Biddle, by W. T. Ray and Henry Kreisinger. $1909.49 \mathrm{pp}$.

Bulletin 412. Comparative tests of run-of-mine and briquetted coal on a locomotive boiler, by W. T. Ray and Henry Kreisinger. 1909. 


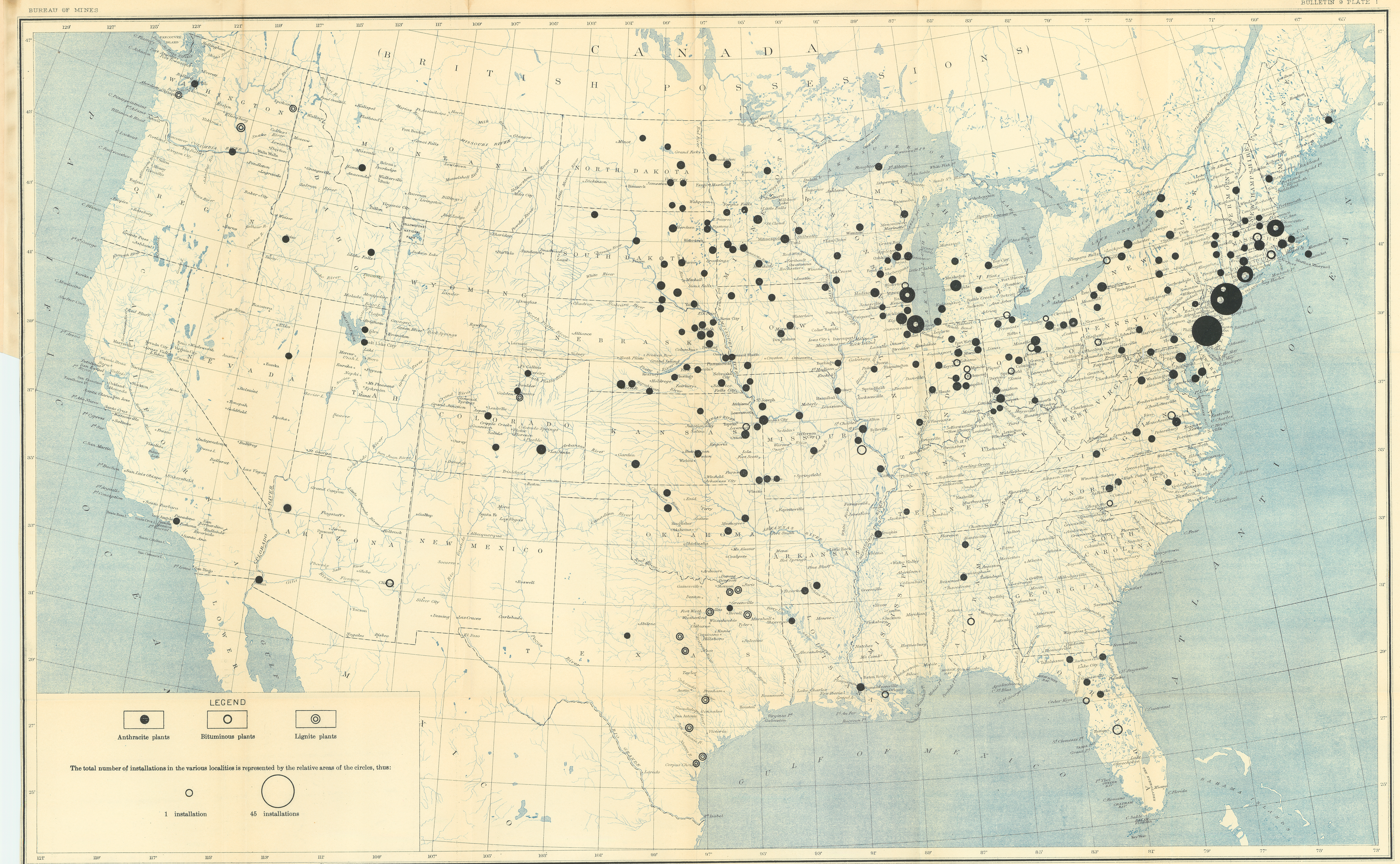




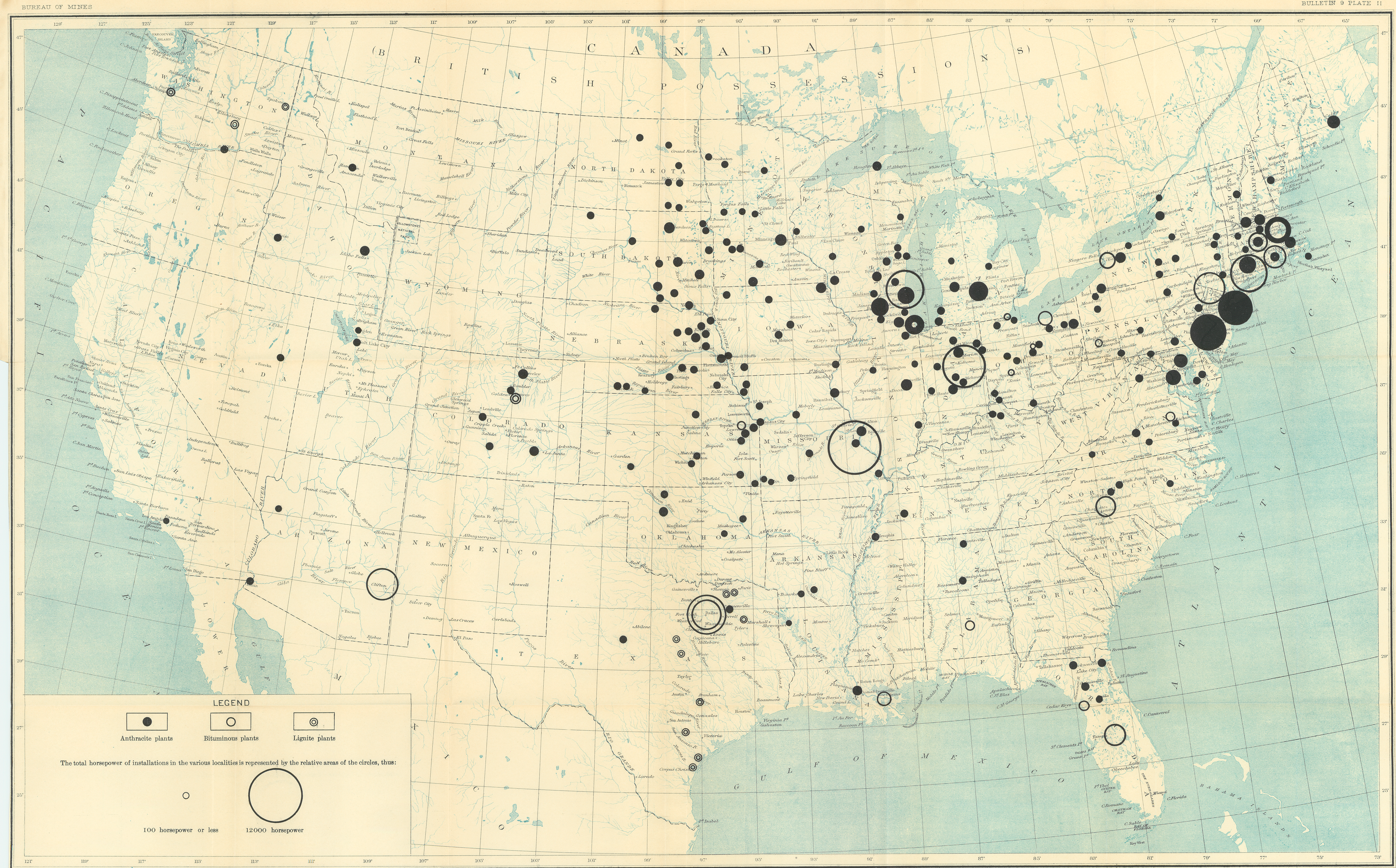

